UNIVERSIDADE DE SÃO PAULO

ESCOLA DE ARTES, CIÊNCIAS E HUMANIDADES

PROGRAMA DE PÓS-GRADUAÇÃO EM TURISMO

ROBERTA DIAS DE MORAES RIBEIRO

Novos Balneários do Oeste Paulista: um olhar para o lazer em praias do interior 


\section{Novos Balneários do Oeste Paulista: um olhar para o lazer em praias do interior}

Dissertação apresentada à Escola de Artes, Ciências e Humanidades da Universidade de São Paulo para obtenção do título de mestre em Ciências pelo Programa de Pós-Graduação em Turismo.

Versão corrigida contendo as alterações solicitadas pela comissão julgadora em 26 de setembro de 2017. A versão original encontrase em acervo reservado na Biblioteca da EACH/USP e na Biblioteca Digital de Teses e Dissertações da USP (BDTD), de acordo com a Resolução CoPGr 6018, de 13 de outubro de 2011.

Área de concentração:

Desenvolvimento do Turismo

Orientador:

Prof. Dr. Edmur Antonio Stoppa

São Paulo 
Autorizo a reprodução e divulgação total ou parcial deste trabalho, por qualquer meio convencional ou eletrônico, para fins de estudo e pesquisa, desde que citada a fonte.

\section{CATALOGAÇÃO-NA-PUBLICAÇÃO}

(Universidade de São Paulo. Escola de Artes, Ciências e Humanidades. Biblioteca)

Ribeiro, Roberta Dias de Moraes

Novos balneários do oeste paulista : um olhar para o lazer em praias do interior / Roberta Dias de Moraes Ribeiro ; orientador, Edmur Antônio Stoppa. - 2017.

$93 \mathrm{f}$. : il

Dissertação (Mestrado em Ciências) - Programa de Pós- Graduação em Turismo, Escola de Artes, Ciências e Humanidades, Universidade de São Paulo

Versão corrigida

1. Lazer - Presidente Epitácio (SP). 2. Lazer Rosana

(SP). 3. Balneários - Presidente Epitácio (SP). 4.

Balneários - Rosana (SP). 5. Políticas públicas. I. Stoppa, Edmur Antônio, orient. II. Título.

CDD 22.ed. - 306.4812098161 
Nome: RIBEIRO, Roberta Dias de Moraes

Título: Novos Balneários Do Oeste Paulista: um olhar para o lazer em praias do interior

Dissertação apresentada à Escola de Artes, Ciências e Humanidades da Universidade de São Paulo para obtenção do título de mestre em Ciências pelo Programa de Pós-Graduação em Turismo.

Área de concentração:

Desenvolvimento do Turismo

Aprovado em: 26/09/2017

\section{Banca Examinadora}

Prof. Dr. Luiz Gonzaga Godoi Trigo

Universidade de São Paulo. Escola de Artes, Ciências e Humanidades

Prof. Dr. André Henrique Chabaribery Capi

Universidade de Araraquara

Prof. Dr. Antônio Carlos Sarti

Universidade de São Paulo. Escola de Artes, Ciências e Humanidades 
Dedico esta pesquisa à Heni, minha mãe, por sempre me apoiar em todas as decisões, ao Rodrigo por todo carinho e compreensão e ao Rio Paraná por ser minha inspiração. 


\section{Agradecimentos}

Primeiramente agradeço a minha família, em especial minha mãe, por sempre estar ao meu lado, por me apoiar em todas as decisões, por acreditar em mim e por ser meu exemplo de vida.

Ao meu orientador, Edmur Antônio Stoppa por sua paciência, atenção, e por me guiar nessa caminhada, minha eterna gratidão.

Ao Rodrigo por compartilhar, desse e de todos os outros momentos comigo, por escutar e incentivar, por ser meu melhor amigo e também o meu amor.

Ao Rogério e Dinorah por tão bem me acolherem, principalmente durante esse processo e me receberem como filha. Vocês também são minha família.

Aos colegas de mestrado, Amanda Baldissera, Amanda Cabral, Daniela Tineo, Eduardo Duarte, Eriberto Sousa e Fábio Ortiz, sou grata pelas trocas de experiências, desafios, inquietações e conhecimentos. Desejo todo sucesso pra vocês.

Aos docentes do Programa de Pós-Graduação em Turismo da USP.

À EACH/USP e todos seus funcionários por sempre serem solícitos e atenderem tão bem, em especial ao Fabiano Prado e ao Marcus Oliveira do serviço da Pós-Graduação e à Sandra Tokarevicz, bibliotecária.

À professora Danielli Cristina Granado, por ter incentivado a seguir esse caminho e por acreditar em mim desde o começo.

Aos professores membros da banca Luiz Gonzaga Godoi Trigo, André Henrique Chabaribery Capi e Antônio Carlos Sarti, por suas contribuições.

Aos professores e alunos do Programa de Pós-Graduação em Turismo da Universidade Federal Fluminense, lugar em que fui muito bem recebida como aluna especial durante o mestrado, onde fiz amigos e tive excelentes experiências.

À cidade de Rosana que maravilhosamente me acolheu e que permitiu ter as melhores lembranças das escolhas que já fiz.

À cidade de Presidente Epitácio por encantar com suas belezas.

E a todas as pessoas que colaboraram durante essa pesquisa. Mesmo que anonimamente, vocês foram essenciais para construção e desenvolvimento dessa dissertação. 
A educação é a arma mais poderosa que você pode usar para mudar o Mundo.

(Nelson Mandela) 


\section{RESUMO}

RIBEIRO, Roberta Dias de Moraes. Novos Balneários do Oeste Paulista: um olhar para o lazer em praias do interior. 2017. 93p. Dissertação (Mestrado em Ciências) - Escola de Artes, Ciências e Humanidades, Universidade de São Paulo, São Paulo, 2017. Versão corrigida.

Este estudo teve como objetivo analisar os balneários das cidades de Presidente Epitácio e Rosana, no estado de São Paulo, como alternativas de lazer, identificando as políticas públicas que os municípios possuem e os projetos futuros. Buscou-se conhecer o entendimento que os responsáveis das secretarias/divisões de turismo e lazer e os frequentadores desses espaços têm em relação às políticas públicas. Mesmo sendo um direito social garantido por lei, o lazer não figura entre as prioridades dos nossos gestores públicos e quando aparece em seus discursos, é diminuído a apenas um de seus conteúdos, geralmente ao físico-esportivo. A metodologia utilizada foi composta pela combinação de pesquisa bibliográfica, documental e empírica, estudo de caso com coleta de dados utilizando-se entrevistas semiestruturadas. As entrevistas foram destinadas aos gestores responsáveis pelas secretarias/divisões de turismo e lazer e aos visitantes dos balneários estudados, resultando num total de 166 entrevistas. Além disso, foi realizada uma observação estruturada com intuito de analisar os fatores externos dos balneários, como conservação do local. Como resultados, identificou-se a dificuldade sobre o entendimento do lazer pelos gestores. Eles configuram o lazer em seu departamento como a agenda de eventos do município e, por consequência, denominam essa agenda como sua política de lazer. Constatamos também que os visitantes dos balneários não percebem a presença física, constante, do poder público municipal, não tendo eficácia a fiscalização das regras estabelecidas pela Prefeitura. Apesar de os balneários possuírem potencial para todo o Oeste paulista, a maioria do público que frequenta os balneários é residente da cidade local. Desta forma, desafios são lançados para as Prefeituras Municipais alcançarem novas fronteiras, como por exemplo, novas parcerias por meio da intersetorialidade; outros métodos de publicidade que atinjam, em especial, as cidades vizinhas; e estabelecer políticas públicas de lazer para além da agenda de eventos.

Palavras-chave: Lazer e Turismo. Balneários Municipais. Presidente Epitácio. Rosana. Gestão Pública Municipal. 


\begin{abstract}
RIBEIRO, Roberta Dias de Moraes. New beaches of the west of São Paulo: a look at leisure on the beaches of the countryside. 2017. 93p. Dissertation (Master of Science) - School of Arts, Sciences and Humanities, University of São Paulo, São Paulo, 2017, Corrected version.

This study aimed to analyze the beaches of Epitacio and Rosana cities in the state of São Paulo as leisure alternatives, identifying its public policies and future projects. It was sought to know how the tourism and leisure department managers and visitors to those spaces understand the local public policies. Even though it is a social right guaranteed by law, leisure is not included among the list of our public managers and when it appears in their speeches, it is reduced to only one of its contents, usually to the physical-sport. The methodology was formed by bibliographical, documentary and empirical research, a case study with data collection, and semi-structured interviews applied to the managers of the tourism and leisure departments and to visitors to the beaches studied, resulting in a total of 166 interviews. In addition, a structured observation was carried out with the purpose of analyzing the external factors of the bathing places, such as site conservation. The results identify a difficulty about the understanding of leisure by managers. They set up leisure in their department as a calendar of events of the municipality, and consequently, they call this agenda as their leisure policy. We also noticed that the visitors to the bathing places do not perceive the physical presence of the municipal public power as constant, which implies the inefficacy of an inspection of the local rules. Although the beaches have potential for the whole of the West of São Paulo, most people who visit the bathing places live in the local city. In this way, challenges are launched for municipalities to reach new frontiers, such as new partnerships through intersectorality; other advertising methods which attack, in particular, neighboring towns; and establish public leisure policies beyond the agenda of events.
\end{abstract}

Keywords: Leisure and Tourism. Municipal Beaches. Presidente Epitacio. Rosana. Municipal Public Management. 


\section{LISTA DE TABELAS}

Tabela 1 - Distâncias de Presidente Epitácio para as principais e, mais próximas,

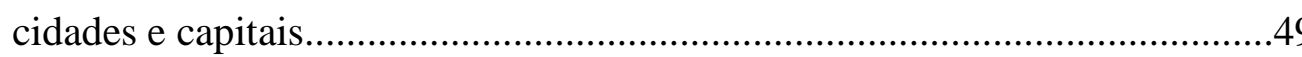

Tabela 2 - Distâncias de Rosana para as principais e, mais próximas, cidades e Capitais. 


\section{LISTA DE GRÁFICOS}

Gráfico 1 - Origem dos frequentadores dos Balneários Municipais de Rosana

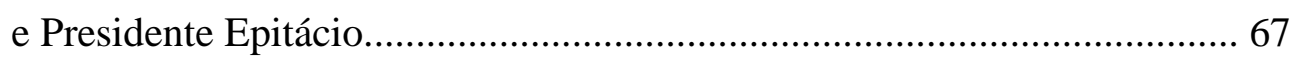

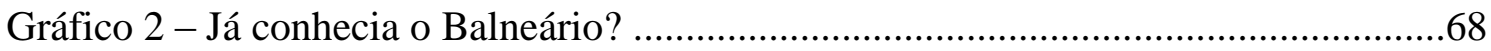

Gráfico 3 - Satisfação dos frequentadores do Balneário de Rosana com relação

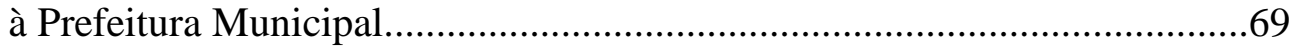

Gráfico 4 - Satisfação dos frequentadores do Balneário de Rosana com relação

à Prefeitura Municipal.................................................................................... 70

Gráfico 5 - Está contente com os eventos que ocorrem no balneário? ............................71 


\section{LISTA DE ABREVIATURAS E SIGLAS}

$\begin{array}{ll}\text { CESP } & \text { Companhia Energética de São Paulo } \\ \text { CNtur } & \text { Conselho Nacional de Turismo } \\ \text { DADETUR } & \text { Departamento de apoio às estâncias } \\ \text { DIVtur } & \text { Divisão de Turismo } \\ \text { EMBRATUR } & \text { Instituto Brasileiro de Turismo } \\ \text { FEPASA } & \text { Ferrovia Paulista } \\ \text { IBGE } & \text { Instituto Brasileiro de Geografia e Estatística } \\ \text { MIT } & \text { Município de Interesse Turístico } \\ \text { Mtur } & \text { Ministério do Turismo } \\ \text { OMT } & \text { Organização Mundial do Turismo } \\ \text { PD } & \text { Plano Diretor } \\ \text { PDDTMR } & \text { Plano Diretor de Desenvolvimento Turístico Municipal de Rosana } \\ \text { PNT } & \text { Plano Nacional de Turismo } \\ \text { SECtur } & \text { Secretaria de Turismo } \\ \text { U.H.E } & \text { Usina Hidrelétrica Engenheiro Sérgio Motta } \\ \text { UNESP } & \text { Universidade Estadual Paulista }\end{array}$




\section{SUMÁRIO}

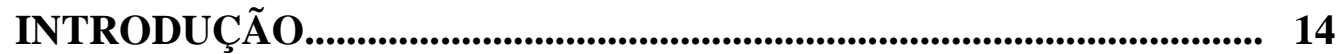

PROCEDIMENTOS METODOLÓGICOS.............................................. 18

O LAZER NA SOCIEDADE ATUAL .................................................. 22

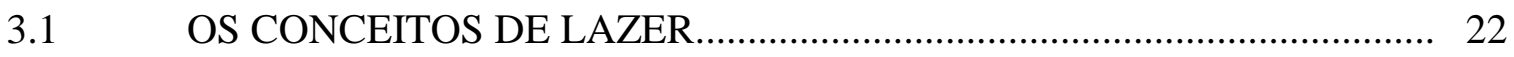

3.2 O TURISMO COMO OPÇÃO DE LAZER, SUA IMPORTÂNCIA E VIVÊNCIAS ............................................................................. 31

3.3 POLÍTICAS DE LAZER E TURISMO E GESTÃO PÚBLICA

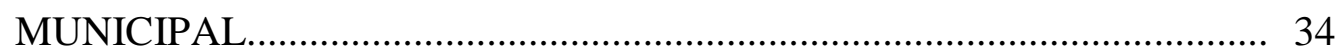

3.4 RECURSOS HÍDRICOS COMO ATRATIVOS DE LAZER ..................... 40

4 PRAIAS DO INTERIOR PAULISTA: O CASO DE PRESIDENTE EPIITÁCIO E ROSANA................................................................... 47

4.1 PRESIDENTE EPITÁCIO: A JOIA RIBEIRINHA................................... 47

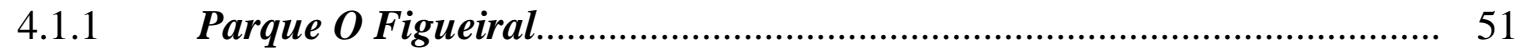

4.1.2 As Secretarias de Turismo e Cultura e de Esportes e Educação................ 52

ROSANA: AQUI COMEÇA SÃO PAULO.............................................. 53

4.2.1 O Balneário Municipal de Rosana .......................................................... 57

4.2.2 A Divisão Municipal de Esportes, Turismo e Cultura ................................ 58

4.3 DISCUSSÃO DOS DADOS COLETADOS NA PESQUISA DE CAMPO. 61

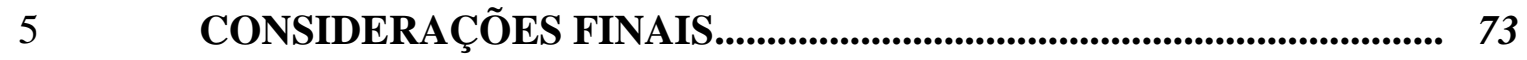

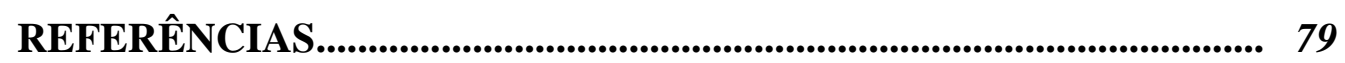

APÊNCICE A - Roteiro de entrevista - Gestores...................................... 91

APÊNCICE B - Roteiro de entrevista - Morador....................................... 92

APÊNCICE C - Roteiro de entrevista - Turistas.................................... 93 


\section{INTRODUÇÃO}

A experiência do lazer está associada à vivência e reelaboração da cultura, num espaço-tempo conquistado pelos sujeitos às imposições da vida no mundo, visando à humanidade mais plena. E é nesse sentido em que se pode considerar o lazer no universo no qual se inclui a atividade turística, como campo de experiências humanas privilegiadas (MARINHO; BRUHNS, 2003).

Sob o olhar de alguns autores, a atividade turística está em contínuo crescimento e em constante busca por ofertar produtos e serviços diferenciados e diversificados, visando suprir os desejos e anseios de uma demanda que exige cada vez mais o novo. Assim, o turismo foi sendo segmentado, na tentativa de corresponder positivamente as expectativas de grupos/populações diferentes, criando produtos e serviços ajustados a tais exigências.

Desde uma pesquisa realizada pelo Instituto Brasileiro de Turismo (EMBRATUR) em 1997, que teve como intuito avaliar o potencial turístico dos municípios brasileiros, os recursos hídricos têm sido apontados como os principais atrativos turísticos. Esse dado despertou o interesse das diversas regiões que têm recursos hídricos próprios para balneabilidade com o intuito de se desenvolver economicamente, a partir das atividades do setor de serviços, como turismo e à demanda de lazer das populações urbanas (ANA, 2005).

Considerando esse cenário e a relação do brasileiro com a água, principalmente as praias, a presente pesquisa justifica-se pela necessidade de se estudar novas alternativas de lazer para o Estado de São Paulo em ambientes aquáticos, ampliando as opções de destinos turísticos diferentes da movimentação "oeste-leste" que existe atualmente, disponibilizando, na maioria dos casos, as mesmas atividades oferecidas no litoral paulista.

As cidades de Presidente Epitácio e Rosana, situadas no Pontal do Paranapanema/SP, apresentam grande exuberância de recursos naturais, principalmente pela presença de dois grandes rios com águas de boa qualidade (Paraná e Paranapanema). Tais recursos levaram esses municípios da região a considerarem o turismo como uma alternativa para o desenvolvimento local, por meio da criação e utilização de balneários municipais.

Sendo o ambiente aquático o principal atrativo dessas cidades, o que questiona-se aqui é referente à gestão pública municipal de tais espaços. Como a experiência dos municípios com relação aos balneários têm se articulado com as políticas públicas de lazer?

Enquanto objetivo geral, o estudo analisará os balneários das cidades de Presidente Epitácio e Rosana, no estado de São Paulo, como alternativas de lazer, identificando as políticas públicas que os municípios possuem e os projetos futuros. Buscou-se, também 
conhecer o entendimento que os responsáveis das secretarias/divisões de turismo e lazer e os frequentadores desses espaços têm em relação às políticas locais.

Para responder nosso objetivo geral, foram estabelecidos cinco objetivos específicos.

- Analisar os balneários de Rosana e Presidente Epitácio, como espaços de lazer para os moradores e turistas da região;

- Compreender quais conteúdos do lazer são considerados no processo de planejamento das políticas públicas nos balneários;

- Identificar, dentro da política pública de lazer dos municípios, quais projetos foram executados; se existem projetos para o futuro; entender o motivo dos que não foram colocados em prática, além de verificar como, por que e para quem as estão sendo planejados;

- Averiguar as opiniões dos visitantes, moradores e gestores a respeito das iniciativas municipais nos balneários.

O estudo será baseado inicialmente pelas considerações relativas ao entendimento de lazer e políticas públicas de Linhares (1998); e sob as perspectivas de Marcellino (2000; 2001); sobre os conceitos de turismo de acordo com Krippendorf (2001), Acerenza (2002); para recursos hídricos como atrativos e conservação dos recursos naturais ANA (2005), Branco; Azevedo; Tundisi (2006).

O desenvolvimento desse trabalho justifica-se a partir de três aspectos:

1. É uma continuidade do Trabalho de Conclusão de Curso que foi desenvolvido no Curso Bacharelado de Turismo - UNESP Campus de Rosana, com o tema "A análise dos recursos hídricos enquanto atrativos turísticos em cidades do Pontal do Paranapanema (SP)”. Nesse sentido, busca-se nesse momento um aprofundamento do tema, relacionando as políticas públicas municipais de lazer e turismo, a fim de entender as similaridades, diferenças e possíveis relações estruturais entre as duas cidades, além de ampliar as discussões teóricas sobre o tema.

2. Entende-se esse tema de estudo como relevante, pois significativa parte dos estudos desenvolvidos a respeito do lazer prioriza o lazer como atividades e recreação e aqui o que se pretende é discutir o impacto das políticas públicas nesse tema, se são planejadas e executadas e se estão como prioridades no plano de governo das prefeituras.

3. A escolha pelas cidades pautou-se na representatividade que possuem como divulgadores de turismo na região do Pontal do Paranapanema como municípios detentores de 
beleza natural que são promovidos pelos seus balneários municipais e, pela ausência de trabalhos com essa ênfase.

O estudo estrutura-se da seguinte forma:

O primeiro capítulo trata-se da introdução desse estudo. Apresentando o tema, os objetivos, geral e específicos, a problemática, justificativa, os objetos de estudo e a estrutura do trabalho.

O segundo capítulo destaca os procedimentos metodológicos, o delineamento da pesquisa, as técnicas utilizadas para coleta de dados, técnicas de amostragem, os indivíduos entrevistados e os processos utilizados.

O terceiro capítulo de revisão bibliográfica "Lazer na sociedade atual” está dividido quatro itens. O Primeiro versa sobre os conceitos do lazer, sob o olhar de alguns autores, suas abordagens e mudanças com o passar do tempo. Nesse capítulo também é demonstrado as relações do lazer com a educação, com o esporte e com o turismo, uma vez que são nesses três segmentos que o lazer se concretiza nos setores do poder público nas cidades pesquisadas. O segundo trata a relação do turismo e do lazer, como ambos acontecem, como são importantes para nossa vivência e como interagem. O terceiro aborda as políticas de lazer e turismo e suas especificidades, buscando compreender como uma das áreas consegue dar suporte para a outra e como em alguns casos elas interagem nas políticas públicas. O último item demonstra os recursos hídricos como atrativos de lazer, fundamentado em diversas pesquisas que apontam os recursos hídricos como os principais atrativos turísticos do Brasil e porque não dizer, também, de lazer.

O quarto capítulo apresenta os municípios estudados, exibindo o contexto histórico, geográfico e econômico de Rosana e Presidente Epitácio, suas secretarias/divisões e seus documentos oficiais e sites institucionais. Além disso, apresenta os balneários municipais estudados, seus principais usos e infraestrutura. Outro ponto desse capítulo é que ele traz informações sobre as distâncias das principais cidades que estão no entorno dos dois munícipios pesquisados.

O quinto capítulo aborda os dados coletados durante toda a pesquisa empírica, a partir das entrevistas e da observação, discussões acerca das respostas obtidas em cada um dos processos. Dessa forma, chega-se a uma conclusão prévia da pesquisa que foi entender como é o relacionamento das secretarias/divisões para com os balneários e identificar as falhas cometidas pelo setor público, apontando possíveis saídas para que os balneários sejam agradáveis para todos: visitantes e poder público. 
O sexto capítulo finaliza o estudo trazendo as considerações finais, respondendo os objetivos propostos e as últimas reflexões e contribuições do estudo. 


\section{PROCEDIMENTOS METODOLÓGICOS}

Em termos metodológicos, a pesquisa foi realizada por meio da combinação da pesquisa bibliográfica, elaborada a partir de material já publicado, com as pesquisas documental e a empírica, pressupondo a inserção da pesquisadora nos locais investigados, além da realização de estudo de caso (TRIVIÑOS, 2013) nos municípios de Rosana e Presidente Epitácio.

Triviños (2013) pondera o estudo de caso como um método de análise de uma unidade particular de forma aprofundada. Nele é necessário um completo suporte teórico que oriente o trabalho do investigador. Para tanto, utilizamos nessa pesquisa o estudo de caso histórico-organizador, que o autor define como aquele com foco na vida de uma instituição, utilizando-se de documentos, publicações e demais registros para melhor compreendê-la.

Utilizamos a abordagem qualitativa e exploratória, pois produz resultados que não podem ser traduzidos em números e busca criar mais familiaridade com o problema proposto, utilizando o método dedutivo, pois parte de leis gerais para chegar a particulares (BIANCHI, 2003). Além disso, para Dencker (2007) uma característica importante das pesquisas qualitativas é a utilização de diferentes técnicas de coleta de dados em campo. Já as pesquisas exploratórias, na perspectiva de Gil (2002) possibilitam maior familiaridade com o problema, com vistas a torná-la mais explícita.

Desenvolvemos a pesquisa bibliográfica por meio da consulta de livros, artigos acadêmicos e periódicos com objetivo de estabelecer a fundamentação teórica do trabalho. De acordo com Marconi e Lakatos (2010) a pesquisa bibliográfica consiste da consulta de trabalhos científicos com dados e informações sobre o tema tratado que é relevante para se obter um conhecimento mais amplo do tema abordado, sendo possível sua análise sobre outro enfoque ou abordagem, podendo chegar a novas conclusões.

Segundo Severino (2007) a pesquisa bibliográfica possibilita obter maior exatidão e proveito dos conteúdos estudados, podendo por meio dela e de uma análise textual, temática e interpretativa conseguir um cenário geral dos objetos estudados. Ainda sobre a visão do mesmo autor, a análise interpretativa do texto permite um olhar crítica a respeito da qualidade, originalidade e profundidade da pesquisa sendo possível problematizar e reelaborar uma síntese do que foi tratado a partir da visão do autor sobre o contexto, cultura e realidade atual.

As consultas das fontes, no levantamento bibliográfico, aconteceram no sistema da biblioteca da Universidade de São Paulo, nas ferramentas da internet como Scielo, Google 
Scholar, SIBI net USP, entre outros. Para essa etapa utilizamos as palavras chave como: Lazer, Políticas Públicas de Lazer e Turismo, Turismo, Balneários de interior.

Para a realização de uma análise de documentos dos sites e nas sedes das Prefeituras Municipais de Presidente Epitácio e Rosana foi realizada, concomitantemente a pesquisa bibliográfica e pesquisa documental. De acordo com Sá Silva; Almeida; e Guindani (2009), a pesquisa documental constitui-se no uso de documentos na investigação científica e tem suas vantagens, pois os documentos são utilizados não somente como fonte de informações, mas como meio de obter esclarecimentos de algumas questões e de provar outras. Além disso, não possuem envolvimento de autores, o que torna o dado mais objetivo.

Dentre os documentos que foram analisados, selecionamos as diretrizes, os planos diretores e os planos diretores de turismo sobre políticas públicas de lazer e turismo das duas cidades pesquisadas, folders, panfletos, materiais de divulgação, dados estatísticos, programas e atividades que possibilitam a prática do lazer, além de estudos relevantes que já foram elaborados sobre o tema.

A pesquisa empírica buscou relativizar as discussões fomentadas no levantamento bibliográfico e documental, realizada por meio observação estruturada (MARCONI; LAKATOS, 2010), estruturado a partir de um roteiro pré-elaborado, e de visitas aos balneários dos municípios nos meses de dezembro de 2016 e fevereiro de 2017. Escolhemos esses períodos por representarem o início e o fim da alta temporada e pelo fato de que encontraríamos duas gestões diferentes, uma deixando a secretaria/divisão e a outra assumindo-a.

Por essa técnica foi possível verificar as infraestruturas destinadas à prática do lazer existentes nos locais, assim como realizar um apontamento sobre as condições de tais equipamentos e da conservação do local. A observação, segundo Marconi e Lakatos (2010, p. 76) consiste em conseguir informações sobre a realidade do ambiente do problema de estudo. Para os autores, de modo geral, a observação ajuda o pesquisador a "identificar e a obter provas".

A fim de complementar a pesquisa empírica foram aplicadas entrevistas semiestruturadas (TRIVIÑOS, 2008) junto aos gestores que atuam diretamente com os balneários, profissionais principalmente das secretarias de turismo, e lazer, que responderam, seguindo um roteiro (apêndice A) previamente elaborado, questões que permitiram reconhecer os usos atuais dos atrativos turísticos, as atividades neles realizadas, os projetos atuais e futuros de lazer e turismo. Em nenhuma das duas cidades é utilizado o termo "lazer" como nome de departamento, contudo, ao analisarmos os sites institucionais das prefeituras e 
seus planos diretores, descobrimos que o setor que mais se aproxima com o termo é a secretaria/divisão de esportes.

Em Rosana, a divisão se denomina "Esportes, Turismo e Cultura", portanto essa foi a divisão em que focamos a pesquisa. Em Presidente Epitácio, duas secretarias foram analisadas: a de "Turismo e Cultura" e a de "Esporte e Educação". Nesse processo identificamos como são realizadas a divulgação destes balneários como atrativos turísticos para os visitantes e como é feito o planejamento dos eventos para os balneários; quais as principais preocupações quanto ao lazer do município; e verificamos a relação do recurso hídrico para com as outras atividades do entorno, já que são esses profissionais os responsáveis por planejar e executar as políticas públicas de lazer e turismo dos municípios.

Segundo Triviños (2013) as entrevistas semiestruturadas possuem questões direcionadas previamente estabelecidas e possibilitam gerar respostas mais diretivas referentes aos questionamentos pontuados. Nesse momento, buscamos por respostas objetivas que se direcionassem ao lazer.

Para Boni e Quaresma (2005) as entrevistas são um meio de obter informações que não foram atingidas por meio da pesquisa bibliográfica e documental. São realizadas com pessoas que entendem do assunto estudado e consiste em uma oportunidade de obter informações mais precisas do assunto estudado, onde podem ser comprovadas informações encontradas em outras fontes e esclarecer as discordâncias identificadas ao longo do estudo (MARCONI; LAKATOS, 2010).

A definição da amostra foi de forma não-probabilística, intencional, para as praias estudadas, bem como os gestores ligados aos espaços e aos documentos analisados, levando em conta critérios de representatividade e acessibilidade (BRUYNE; HERMAN; SCHOUTHEETE, 1991) e por saturação para os frequentadores ligados aos espaços (MAGNANI, 2003) a serem pesquisados em Rosana e Presidente Epitácio.

Ao todo foram realizadas seis entrevistas com os gestores, dois em Rosana - sendo uma com o gestor do governo 2013-2016 e outra com o gestor da administração 2017-2020 ambos da divisão de Esportes, Turismo e Cultura. Em Epitácio foram feitas quatro entrevistas - duas com os gestores de 2013-2016 e outras duas com os gestores de 2017-2020 representando as secretarias de Turismo e Cultura e a de Esportes e Educação.

Além da entrevista com os gestores foi realizada uma entrevista estruturada (TRIVIÑOS, 2008) aplicada com o intuito de conhecer os frequentadores dos balneários municipais, procurando identificar, principalmente, se são turistas ou moradores locais; como obtiveram informações sobre o local; qual a forma que praticam o lazer; e qual sua opinião a 
respeito das iniciativas municipais voltadas para o lazer e, sobretudo, comparar tais questões com os discursos feitos pelos gestores municipais.

Foram aplicadas um total de cento e sessenta entrevistas. Noventa dessas na cidade de Rosana (quarenta e cinco em dezembro de 2016 e quarenta e cinco em fevereiro de 2017). Já as outras setenta aplicadas em Presidente Epitácio (trinta e cinco em dezembro de 2016 e trinta e cinco em fevereiro de 2017). As pessoas escolhidas para a entrevista foram eleitas por grupo de visitantes. Apenas uma pessoa do grupo familiar ou de amigos foi entrevistada, para que não houvesse influência nas respostas e, principalmente, para que conseguíssemos um número mais exato sobre a origem dos frequentadores.

Ao final da pesquisa, obtivemos um total de cento e sessenta e seis entrevistas, contando os seis gestores e os cento e sessenta visitantes dos balneários municipais. 
O LAZER NA SOCIEDADE ATUAL

Nessa seção, para aproximarmos com o tema central da pesquisa, apresentaremos os conceitos do lazer e sua evolução histórica, bem como as relações que o lazer faz com o turismo, as políticas públicas que os regem, e como ele é utilizado nos recursos hídricos, em especial, nos rios.

\subsection{OS CONCEITOS DE LAZER}

Quando tratamos de lazer e turismo, precisamos compreender as discussões epistemológicas que acercam tais práticas, principalmente para que não haja desencontros conceituais. Mesmo sabendo que pertencem a dois campos acadêmicos distintos, nesta dissertação não iremos fragmentá-los por considerar que possuem ligações claras. Dessa forma entendemos aqui, que o turismo é também uma forma de lazer e, portanto, seus estudos estão em constante diálogo com os estudos do lazer.

Mesmo considerado como um campo recente de pesquisa no Brasil o lazer já apresenta comunicação com a área das ciências humanas e sociais. Gomes (2008) afirma que existe uma necessidade em construir outros referenciais para o turismo - para além dos oriundos da Economia e da Administração - e que o campo de Estudos do Lazer pode trazer relevantes contribuições para a construção de conhecimento e novos apontamentos que permitam democratizar, ainda mais, essa área.

As pesquisas relacionadas com o lazer tenderam a estudar as tensões que percorrem o tempo, o não trabalho e as manifestações culturais que permeiam esse âmbito que são divulgadas e compreendidas de diferentes formas. Mesmo nos meios de comunicação mais formais, as pessoas o mencionam como algo ingênuo, quase sempre nas ilustrações de futilidades, ou seja, pouco relevante quando comparado a outros elementos/assuntos, considerados, então, como prioritários (trabalho, saúde, educação, economia), além de ser tratado como fuga do cotidiano. Essa percepção, pautada no senso comum, acaba por diluir o significado da palavra em abordagens superficiais transmitidas por meio das comunicações em massa.

Sendo assim, é relevante aprofundarmos a discussão sobre o conceito de lazer que utilizaremos aqui. Em relação ao termo que se utiliza para caracterizar o lazer, os pesquisadores da área têm se apropriado e empregado de diferentes conceitos para caracterizar o tempo em que as vivências de lazer podem ser realizadas Entre eles, encontramos tempo livre, conquistado, liberado, disponível, roubado, entre outros. 
Sobre o termo livre, utilizado por diversos autores, Marcellino (2002) traz em suas discussões, se realmente este pode ser considerado liberto de repressões, determinismos e normas de conduta social.

Os autores que tratam o lazer como tempo conquistado, discutem dois pontos. O primeiro remete à conquista do tempo de descanso remunerado em função das lutas trabalhistas, grande parte sucedidas no decorrer do século XIX em quase todo o mundo ocidental (CHEIBUB, 2009).

Não devemos, contudo, esquecer que a própria diminuição de 16 para oito
horas de labuta, que aumentou o tempo de não-trabalho, denota que este
tempo de trabalho foi também conquistado, o que nubla a exclusividade do
termo. Quando tratamos de tempo disponível implica supor que o sujeito
dispõe de maiores possibilidades para se permitir criar, fruir, escolher e
realizar o que realmente quiser. Será que esta maior disponibilidade é
específica deste período? Será que isto acontece em todos os contextos
sociais? Essas são questões que não podem ser negligenciadas, nem sempre
são consideradas adequadamente e, no limite, podem incorrer no equívoco
de supervalorizarem o lazer em detrimento do trabalho, enquanto parece
mais interessante considerar ambos como tempos sociais de importância
similar (CHEIBUB, 2009).

Outros autores como Dumazedier (1973) utilizaram a expressão tempo de lazer, que não pode ser definido apenas pelo tempo de não trabalho, pois no período das horas não trabalhadas podemos praticar atividades que não são determinadas nem por lazer e nem por trabalho.

Partindo dessas concepções sobre os conceitos aplicados ao lazer que provêm do sentido de "não trabalho", seria possível pensar no inverso, no tempo de "não lazer" para classificar o trabalho? $\mathrm{Na}$ atualidade em que vivemos seria mais fácil e correto dizer que temos tempo de obrigatoriedade e não obrigatoriedade, que, principalmente na vida urbana encontramos disparidades nesses tempos. Geralmente as pessoas dedicam um tempo excessivo ao trabalho e suas obrigações, enquanto o tempo livre se restringe aos pelos intervalos que existem entre esses momentos e em espaços variados.

Nessa pesquisa visaremos os dois aspectos estruturais que caracterizam as opções de lazer: o tempo e o espaço. São nesses elementos que identificamos as atitudes dos indivíduos em relação às práticas de lazer, assim como seu envolvimento com o espaço onde ela ocorre.

Com o intuito de delinear as problemáticas que limitam o entendimento do lazer de modo mais geral e amplo, descreveremos a seguir as visões funcionalistas tratadas pela área, bem como a de caráter mercantilista, associada ao lazer mercadoria. Conforme Marcellino 
(2006) são encontradas pelo menos quatro abordagens funcionalistas: a moralista, a romântica, a compensatória e a utilitarista.

A abordagem moralista visa preservar a ordem estabelecida e os valores dominantes da sociedade - manutenção do "status quo" - motivada pelo caráter ambíguo do lazer visto como "faca de dois gumes" (MARCELLINO 2006, p. 48). De acordo com Camargo (1998), a efetivação de valores suspeitos, inconvenientes e desagregadores da tranquilidade, da ordem e da segurança se enfatiza por meio da ocasião. Ou seja, mesmo que o lazer seja considerado o tempo e o espaço para vivências culturais, sociais e políticas que contribuam para a melhoria da qualidade de vida das pessoas, o mesmo, sendo um fenômeno social, envolvem pessoas, que tem em seu tempo de lazer a liberdade em realizar atividades consideradas ilegais ou negativas.

A abordagem romântica, na visão de Marcellino (2006), é a que desvaloriza o presente e mantém os valores da sociedade tradicional, valorizando o passado como ideal e buscando manter a cultura de antigamente. Isso para conservar a ideologia e os costumes da classe dominante.

A abordagem compensatória restringe o lazer a momentos que possam compensar a insatisfação dos indivíduos na sociedade, ajudando-os a se adequarem ao sistema vigente. Segundo Dumazedier (2004) o trabalho, a cada dia que passa, é apenas um elemento para a sobrevivência e obtenção de renda as pessoas. Por meio do não trabalho é também um meio de conquistar o lazer que pode auxiliar na compensação dos conflitos da vida cotidiana do trabalho. Assim, em certos aspectos, o tempo de trabalho está sendo considerado como "ganha lazer", onde as pessoas trabalham para obter lazer, felicidade, prazer e qualidade de vida.

Krippendorf (2001, p. 37), afirma que na sociedade industrial, e na sociedade de serviços, todos aqueles que trabalham sentem a necessidade de uma compensação ou prêmio de consolação, de férias ou viagens que permitem as pessoas retornarem e sobreviverem a mais uma rotina alienante de trabalho. Mas deve-se ressaltar que mesmo que o lazer seja uma prática voltada para as vivências culturais, sociais e políticas dentro de um determinado tempo e espaço, trata-se de um fenômeno que envolve pessoas que estão em seu tempo "livre" usufruindo de uma liberdade não controlada e que, portanto, podem desenvolver atividade negativas ou ilegais (CAMARGO, 1998).

A abordagem utilitarista, por sua vez, trata o lazer como elemento para manter a ordem estabelecida por meio de um lazer que traga mais produtividade, uma redução do lazer à função de recuperação da força de trabalho ou sua utilização como instrumento de 
desenvolvimento institucional. É também uma forma de recuperar as forças de trabalho ou reduzir os problemas sociais. Essa abordagem busca um significado, uma utilidade para o lazer, principalmente como uma fuga das tensões do cotidiano, do trabalho, dos problemas sociais e redutor de violência. Todavia para que o lazer seja propulsor desses benefícios deve ser trabalhado envolvendo os demais setores da sociedade (saúde, esporte, educação, entre outros) de maneira ampla (MARCELLINO, 2006).

Como apresentado anteriormente, na sociedade atual o lazer é visto, principalmente, por meio dessa abordagem funcionalista, que o enxerga enquanto elemento vivenciado de modo a ajudar as pessoas a conviverem com as injustiças sociais observadas no cotidiano, colaborando com a manutenção da situação social vigente e também com a elaboração de políticas públicas de lazer reduzidas. Segundo Marcellino (2007) esse entendimento de lazerfuncionalista - pode ser categorizado como "lazer mercadoria" que se traduz como o entretenimento de massa, produzido pela Indústria Cultural.

[...] - O que se percebe hoje é uma clara alusão ao entretenimento como "lazer mercadoria". Não se trata de atividades populares ligadas á alma da população, mas de atividades "popularescas", no sentido de nivelamento "por baixo", com o único objetivo de "desviar a atenção de", e esse "de", quase sempre, pode ser entendido como a triste realidade pessoal e social dos seres humanos. [...] (MARCELLINO, 2007, p.49).

Vários são os conceitos que permeiam as discussões sobre o lazer. E com o passar dos anos vários autores de diversas áreas foram adaptando o termo à realidade atual com base no ocorrido no passado. O conceito desenvolvido pelo sociólogo francês Dumazedier, na década de 1970, é o que influenciou diretamente o campo de estudo no Brasil. Para esse autor o lazer consiste de:

Um conjunto de ocupações às quais o indivíduo pode entregar-se de livre vontade, seja para repousar, seja para divertir-se, recrear-se e entreter-se ou ainda para desenvolver sua formação desinteressada, sua participação social voluntária, ou sua livre capacidade criadora, após livrar-se ou desembaraçar-se das obrigações profissionais, familiares e sociais (DUMAZEDIER, 1973, p. 34).

Ao considerar o lazer em um tempo separado do tempo de trabalho, Dumazedier o compreende como fruto da civilização nascida da Revolução Urbano-Industrial, que, segundo ele, artificializou o tempo e o espaço cotidiano do indivíduo. O autor traz, inclusive, uma classificação do que não seria considerado lazer (1973, p. 31): 
1. O trabalho profissional.

2. O trabalho suplementar ou trabalho de complementação.

3. Os trabalhos domésticos (arrumação da casa, a parte diretamente utilitária da criação de animais destinados à alimentação, do bricolage e da jardinagem).

4. Atividades de manutenção (as refeições, os cuidados higiênicos com o corpo, o sono).

5. As atividades rituais ou ligadas ao cerimonial, resultantes de uma obrigação familiar, social ou espiritual (visitas oficiais, aniversários, reuniões políticas, ofícios religiosos).

6. As atividades ligadas aos estudos interessados (círculos e cursos preparatórios de um exame escolar ou profissional).

De acordo com Marcellino (2000, 2014, p. 34) o lazer é na sociedade atual, fruto da sociedade urbana e industrial, representada por:

[...] uma cultura vivenciada no "tempo disponível", não em contraposição, mas em estreita relação com o trabalho e as demais esferas de obrigação da vida social, combinado com os aspectos tempo e atitude, no valor da atuação no plano cultural [...], e como instrumento de mudança social [...].

Para o autor, esse tempo disponível seria um tempo privilegiado para a vivência de valores que contribuam para mudanças de ordem moral e cultural (MARCELLINO, 2000). Assumindo o lazer como cultura o torna mais amplo, entendendo-a como "[...] conjunto global de modos de fazer, ser, interagir e representar que, produzidos socialmente, envolvem simbolização e, por sua vez, definem o modo pelo qual a vida social se desenvolve" (MACEDO, 1984, p. 35), e não apenas como arte e espetáculos.

Resultado da Revolução Industrial do século XVIII, o lazer se consolidou a partir das lutas e conquistas das classes operárias por maior tempo de lazer e descanso, num contraste de excessiva carga horária de trabalho nas fábricas, em más condições de sobrevivência (MARCELLINO, 2008; REQUIXA, 1980; MELO; ALVES JR., 2012; GOMES, 2008). Nesse sentido é possível pensar em duas perspectivas para concebermos o lazer. A primeira trata-se de uma forma de recuperação das forças de trabalho e a segunda pode ser vista como amplo tempo e espaço de participação e mobilização política (CAMARGO, 1992; MARCELLINO, 2008; GOMES, 2008).

A primeira perspectiva causou maiores atenções na sociedade capitalista atual, já que possuía um caráter mais capitalista, voltada para a produção e o consumo. Mas por outro lado, essa mesma perspectiva diminui o lazer a um instrumento que vive em contraposição ao trabalho, ou seja, afirmando que as pessoas trazem significado a suas vidas somente por meio das obrigações profissionais, enquanto que as atividades relacionadas ao não trabalho e as demais esferas da vida são evidentemente desprestigiadas. 
Por esses motivos, o lazer tem sido desvalorizado em nossa sociedade. Tal desvalorização vem em contrapartida ao tempo de trabalho, já que as pessoas dedicam mais tempo às obrigações que aos momentos livres - que por natureza são menores que o de trabalho. Para Bruhns (2004, p. 95) essa é uma reflexão importante, pois:

\begin{abstract}
[...] na medida em que nossa vida é regida pela concepção de tempo como produtividade, rentabilidade e lucro ("tempo é dinheiro"), raramente nos damos conta o quanto desprezamos a dimensão afetiva e emocional nas relações humanas, fato demonstrado na justificativa de não termos tempo para "perder" com um amigo quando este nos requisita para um desabafo; quando não "temos tempo" para ajudar os necessitados; para esquecer da vida nos braços de quem amamos; para brincar com nossos filhos; para assistir a um por do sol. Comportamentos adjetivados como "perda de tempo" num mundo voltado para o trabalho, onde a lógica do "fazer" e do "nunca se render" domina o panorama.
\end{abstract}

Apesar dessa concepção devemos enxergar o lazer pela perspectiva de que é algo que foi conquistado pelos trabalhadores. Segundo Aoun (2001) essa luta transformou a nossa sociedade numa capacidade de demanda de lazer, que por sua vez, propiciou uma gama de oportunidades e possibilidades para empreendimentos, lucros e consumos, dentre os quais o turismo está incluído.

Por outro lado, não podemos conduzir o lazer por uma única visão, ele se complementa com outros conteúdos, que Dumazedier (1980a) classifica como físicoesportivos, manuais, sociais, intelectuais, artísticos. Camargo (1989) acrescenta um novo conteúdo ao lazer, o turístico, tornando-os seis interesses do lazer. Cada um destes é responsável por uma vasta lista de possibilidades à vivência do lazer. O turismo, por sua vez, ao ser acrescentado como um dos interesses, reforça o diálogo entre as duas áreas e exige mais estudos dessa relação.

Outra relação importante que se faz presente no lazer, é com a educação. Neste caso a chamada educação para e pelo lazer (MARCELLINO, 2008). O lazer quando envolvido com a educação se permite a uma característica de fomentá-lo não somente nas áreas de entretenimento e descanso, mas também como provedor de crescimento e desenvolvimento pessoal e como possibilidade de reivindicação social, ou resgate da cidadania, tudo por meio da participação cultural (STOPPA, 2005).

Por esses motivos o lazer deve ser visto e compreendido como um tempo privilegiado que pode promover mudanças de ordem moral e cultural, como um canal de mobilização político, de produção cultural e de conquista da cidadania que não pode, simplesmente, ser restrito às atividades vivenciadas no cotidiano ou como uma alternativa de superação de problemas sociais. Todavia, esse entendimento mais amplo do lazer não é 
suficiente para alcançar essa compreensão. O desafio que se enfrenta é estimular a participação da população a buscar superar as muitas barreiras socioculturais presentes no lazer, que colaboram com as injustiças e os problemas presentes no cotidiano.

A participação aqui descrita não corresponde as vivências e as práticas do lazer somente, mas representa as atitudes que os indivíduos podem assumir. No conformismo, o indivíduo concorda com as imposições da sociedade sem, no entanto, buscar e propor mudanças. Já nos níveis de participação crítico e criativo nas vivências de lazer, buscam-se mudanças e melhorias nas condições atuais e na qualidade de vida dos sujeitos (DUMAZEDIER, 1980).

A participação é entendida por Marcellino (2006, p.17), como “[ [...] a atividade crítica e criativa de sujeitos historicamente situados", sendo considerada como uma das bases para a mudança da sociedade, mudança em busca da instauração de uma nova ordem social e cultural.

É importante salientar que a participação só existe quando e se for conquistada, pois de acordo com Demo (1988) ela faz parte de um processo e não de um produto acabado, sendo imprescindível que a sociedade de forma geral, afronte as injustiças e as desigualdades sociais expostas na atualidade lutando por tal participação.

Esse olhar de participação para o entendimento do lazer é essencial para ir de encontro a sua vivência acometida pelo funcionalismo, onde é tido como uma fuga do cotidiano, uma válvula de escape. Esse pensamento é compartilhado pelas pessoas por ser entendido como algo com menor importância perante nossas demais necessidades como educação, saúde, segurança, alimentação, entre outros. Ou seja, as pessoas tendem a eleger suas prioridades, estarem satisfeitos, para somente depois poder estabelecer ao lazer sua importância.

A grande maioria das pessoas não encontra em seus cotidianos, um tempo para usufruir de um momento de lazer. Isso porque não se sentem "permitidos" para tal prática. A culpa por não estar sendo produtivo é maior do que exercer e aproveitar seu direito ao tempo livre.

Nossa sociedade nos cobra, intensamente, por papeis sociais produtivos, ou seja, o trabalho. Um individuo que não tem trabalho é tido como alguém desocupado e sem interesses de se desenvolver. Por esse fator, torna-se difícil as pessoas se liberarem para praticar algo que goste, sem remuneração e que não traga prestígios como o lazer. Normalmente, o tempo que as pessoas querem disfrutar de lazer, por meio do turismo, acaba sendo em viagens de férias, certamente por ser o inverso do tempo de trabalho cotidiano, mas 
garante sua produtividade e, portanto, sua representatividade perante a sociedade, conforme afirmam Stoppa; Trigo; Isayama (2015, p. 145).

o turismo será cada vez mais um atrativo para os brasileiros enquanto possibilidade de lazer, de status e de vivenciar novas experiências. Turismo é uma atividade importante no País e um atrativo para as pessoas que buscam o que fazer em seu tempo disponível, longe do trabalho e das obrigações e responsabilidades que permeiam nosso cotidiano.

Como se não bastasse a sociedade compartilhar dessa visão reducionista do lazer, o poder público também tem partilhado esse princípio em muitas cidades do país, uma vez que compreende o lazer como divulgador de ações pontuais e de eventos municipais, buscando por meio do lazer a solução dos problemas das diversas áreas sociais.

Nesse sentido, as barreiras encontradas para as vivências do lazer, tanto qualitativa, quanto quantitativamente, podem ser minimizados por meio da efetiva participação cultural. Marcellino (2006) caracteriza: as barreiras intraclasses, como as de faixa etária, gênero, de acesso a espaços e equipamentos de lazer, da violência, dos estereótipos, entre outras; e as barreiras interclasses, como o fator econômico e o nível de instrução.

Inseridas nas classes sociais, as barreiras intraclasses são aquelas, dentre as quais estão às de faixa etária, em que os maiores problemas permanecem, principalmente, nos extremos do ciclo vital (crianças e idosos): nas vivências de lazer das crianças, vistas como adultos em miniatura, seres não produtores de cultura, apenas em preparação para o mercado de trabalho; ou nos idosos, já afastados do mercado de trabalho, excluídos do contexto de produção e lucro (MARCELLINO, 2006).

Diante desse contexto, uma promoção do lazer para e pela criança deve ser estabelecida por meio de políticas públicas, que na indústria cultural se desenvolvem atividades pelas crianças dentro do convívio social, no momento de brincar.

Já referente aos idosos os cuidados das políticas públicas têm que estar em educa-los para o tempo disponível, em promover iniciativas de troca de experiências, etc. (SILVA; MARCELLINO, 2006; BARBOSA; CAMPAGNA, 2006).

Por se tratar de uma idade específica que tem maior tempo livre, iniciativas que envolvam práticas de lazer trazem benefícios para a mente e para o corpo. Os idosos já passaram pelo tempo de trabalho e a ausência dele ao invés de ser um alívio acaba trazendo diversos problemas de saúde pela falta de ocupação, como a depressão, por exemplo, uma das doenças que mais atinge os brasileiros. É claro que nenhuma questão pode-se generalizar, mas a verdade é que a mudança de rotina altera os sentidos de uma pessoa e tal mudança acarreta 
pontos negativos para vida. Sendo assim, o lazer e suas práticas devem ser considerados nessa idade como oportunidade de criação, integração e desenvolvimento social, trazendo esse indivíduo para um outro meio de produtividade.

Outra barreira que precisa de dedicação por parte do poder público e da sociedade é a barreira intraclasses de gênero. Camargo (1992) indica que, primeiramente isso ocorre porque ainda se encontra machismo nas pessoas, e em segundo pela dupla jornada de trabalho das mulheres: no mercado profissional e nos lares, cuidando da casa e da família.

Em relação às barreiras de acesso aos espaços e equipamentos, o lazer se limita, inicialmente pelo fato de estarem concentradas nas localidades mais valorizadas de um município, que na maioria das vezes se encontram nos centros das cidades. O que se deve levar em consideração é que nos dias de hoje, com o crescimento desordenado dos centros urbanos, as pessoas, que mais precisam dos espaços públicos, vivem cada vez mais nas regiões periféricas das cidades e, portanto, mais distantes dos equipamentos de lazer (BRENNER; DAYRELL; CARRANO, 2005).

Um segundo ponto a ser questionado é o fato de que pessoas menos favorecidas financeiramente são as que menos têm condições de se inserir em espaços destinados às vivências de lazer e em ações e com espaços e equipamentos de lazer no seu bairro (MARCELLINO, 2008). Em geral os equipamentos de lazer estão localizados nos centros das cidades, fazendo com que a população que vive nas periferias tenha menos acesso a eles, seja por distância, recursos financeiros ou por não se sentirem pertencentes nessas localidades.

Esse é o terceiro ponto a ser discutido: sobre essas pessoas que já não tem estímulos a participar e de usufruir dos equipamentos de lazer, também adotarem tais espaços como "santuários" e não se sentirem pertencentes a esses locais como, cinemas, museus, teatros, shoppings, e então, não se permitirem a estar neles (MARCELLINO; BARBOSA; MARIANO, 2008). No caso de um museu, por exemplo, existem pessoas que não se reconhecem em tais espaços, mesmo morando próximo a eles e/ou tendo seu contexto histórico retratado ali. Ou seja, o ar de santuários deixa exposto que esses lugares/santuários não estão abertos a todos.

Muitas são as barreiras encontradas para as vivências do lazer e, por consequência, muitos são os desafios para obter um lazer mais participativo, democrático, que seja igualitário. Entendendo o lazer de maneira ampla, com estreitas relações com a cultura, qualidade de vida, cidadania e educação, temos o caminho para superar as restrições das barreiras socioculturais. Assim, o desenvolvimento de política pública de lazer deve passar pela consideração do: 
[...] entendimento amplo do lazer, em termos de conteúdo, pela consideração do seu duplo aspecto educativo, suas possibilidades enquanto instrumento de mobilização e participação cultural, as barreiras socioculturais verificadas, e por outro lado, pelos limites da Administração Municipal e a necessidade de fixação de prioridades a partir da análise de situação (MARCELLINO, 1996, p. 27).

A partir dessas considerações, observa-se que muitas devem ser as mudanças e superações dedicadas a construção de uma sociedade mais justa, mas que por outro lado tem, por meio da participação social, o lazer como alternativa para minimizar as barreiras intraclasses e interclasses e promover a democracia, igualdade e acesso à sociedade.

Por fim, para que tudo se encaixe, necessitamos de políticas públicas específicas e eficazes por parte do poder público, para que o lazer seja reconhecido como uma necessidade as pessoas de todas as idades.

Mesmo tendo conhecimento de que o lazer foi colocado como direito social de todos, a partir de 1988 pela Constituição Brasileira, e, portanto, foram estabelecidas políticas públicas, nos três âmbitos de governo, Federal, Estadual e Municipal, direcionadas para o lazer.

Um exemplo de política que foi estabelecida no estado de São Paulo foi a Lei de Incentivo Paulista Federal - Segundo Tempo, $\mathrm{n}^{\circ}$ 11.438/2006 que permite que empresas e pessoas físicas invistam parte do que pagariam de Imposto de Renda em projetos esportivos aprovados pelo Ministério do Esporte. As empresas podem investir até 1\% desse valor e as pessoas físicas, até 6\% do imposto devido (BRASIL, 2006).

No entanto, não se garante a efetividade dessas políticas públicas apenas por um marco legal, muito menos sua qualidade ou sua democratização de acesso (MOESCH, 2012).

Dessa forma, é essencial a participação da população para reivindicar seus direitos perante, e auxiliar na construção e no direcionamento de projetos que envolvam o lazer junto às prefeituras municipais, para que essa possa oferecer novas opções de lazer e garantir uma maior inserção das pessoas nos espaços públicos. Uma opção válida e que deve ser considerada nesse processo para que se coloque em prática é a atividade turística.

\subsection{O TURISMO COMO OPÇÃO DE LAZER}

Muitas são as pesquisas que questionam se a atividade turística é fruto da modernidade ou se já existia antes dela. Deixamos claro aqui que não entraremos no mérito dessa discussão nesse trabalho, uma vez que entenderemos o turismo como uma das muitas 
opções que o lazer possui, e que, por sua vez, trata-se de um elemento que surgiu com a modernidade e pelas conquistas trabalhistas.

Por outro lado temos o turista que segundo Urry (2001, p. 269) é uma das características da experiência moderna, e que:

[...] é importante salientar que o moderno turismo começou a ganhar feição no século XIX, quando o deslocamento humano deixou de ser uma contingência de momentos difíceis ou especiais para afirmar-se como lazer e entretenimento.

É de conhecimento que as viagens de negócios e as peregrinações já existiam bem antes da modernidade, porém, eram práticas que só eram proporcionadas a pessoas com maior poder aquisitivo e poder social. Dessa forma, esse viajante não deve ser considerado um turista, mas sim um viajante social como, já que não possui características específicas do turista que conhecemos nos dias de hoje. Castro (1999, p. 80) compartilha desse pensamento: "Diferente de quem viaja a negócios, a estudo ou em busca de saúde, o turista é basicamente movido pela curiosidade, pela vontade de visitar algum lugar apenas por prazer". Outra autora que partilha desse pensamento é Miceli (2001, p. 50) afirmando que o turista que conhecemos na atualidade trata-se "como sendo aquele que procura prazer (pleasure seeker) e que vai acabar por produzir, no seu extremo, a figura do mero 'espectador'”.

Um equívoco que foi cometido muitas vezes pela academia - nas pesquisas - foi a comparação de turismo com o Grand Tour ${ }^{1}$. O turismo (apesar de considerado um campo de estudo recente) possui estudos que se dedica a pesquisar seus fenômenos, suas práticas e novas formas de inserção e democratização para população, enquanto o Grand Tour foi restrito a pessoas com muito dinheiro, mostrando que outro fator que caracteriza as diferenças entre esses dois é a motivação das pessoas em praticá-las, como aponta Araújo (2001, p. 53) ao caracterizar o Grand Tour: “Ao longo dos séculos XVII e XVIII, e ainda no século XIX, somente os muito ricos podiam exercer essa experiência de viagem específica, associada, via de regra, ao desejo de conhecimento e de formação particularizada”.

Todavia, quando aceitamos a viagem como uma forma de lazer só poderemos considerá-la turismo no momento em que passa a ser organizada em alguns lugares e a ocorrer em períodos regularizados (URRY, 2001). Castro (2001) faz uma passagem sobre o tema para explicitar as mudanças na estrutura da viagem que ocorreram com o passar dos anos:

\footnotetext{
${ }^{1}$ O Grand Tour se insere no contexto da Renascença Italiana, que ajudou a divulgá-la, impulsionando o ímpeto pelas viagens motivadas pela aprendizagem e aquisição de cultura, mas também teria motivado as viagens mercantis (LICHORISH E LENKINS, 2000).
} 
A gênese do turista como um tipo social está relacionada a processos culturais mais amplos. Para que a ideia de viajar por prazer vingasse no imaginário ocidental, foi preciso que uma série de mudanças estéticas e intelectuais fossem sendo gradativamente desenvolvidas: a valorização da natureza, a "descoberta" das paisagens e de cenas "pitorescas", a noção de lazer como forma de relaxar do stress da vida moderna e a ascensão do individualismo, entendido como processo histórico que generalizou a moderna concepção de indivíduo, ser dotado de uma subjetividade em alguma medida descontínua em relação à sociedade. Tudo isso também está relacionado aos fenômenos de urbanização, industrialização, mudança nas condições de trabalho e desenvolvimento do capitalismo. Essas transformações criaram as condições para o surgimento dos primeiros empreendimentos voltados para o turismo como uma atividade de massas. $\mathrm{O}$ surgimento dos agentes de viagem, a construção de ferrovias e de hotéis modernos possibilitou a transformação do Grand Tour que os jovens aristocratas ingleses faziam desde o século XVI numa oportunidade aberta a um número cada vez maior de pessoas. Desse modo, gradativamente nasceu o que hoje conhecemos como a "indústria" do turismo (Castro, 2001, p. 80).

Não podemos deixar de considerar, a discussão acerca do turismo de massa que cerca as pesquisas em turismo. De acordo com Araújo (2001) a viagem vem sofrendo alterações com o tempo. Primeiro porque houve, durante a história do turismo, a transição da viagem individualizada para a viagem como experiência compartilhada em grupo, tornando a viagem como algo mais globalizada, generalizada. Sendo assim, no início dessas transformações estiveram presentes apenas segmentos da alta classe média.

Por ter sido algo mais restrito, eram poucas pessoas antes do século que tinham o poder de realizar viagens e era ainda menor o número de pessoas que não participavam das classes sociais mais elevadas que tinham essa oportunidade. Para Urry (2001), em geral quando essas pessoas resolviam viajar era, na maioria das vezes, pelos mesmos motivos: trabalho ou negócios.

Conforme o mesmo autor, o turismo de massa surge do momento em que se percebe que boa parte da população, quase todo o tempo, viajava para algum lugar com a finalidade de contemplar e ali permanecer por motivos que basicamente, não tinham ligações com seu trabalho.

Nos dias de hoje, tem-se criticado essa modalidade de turismo com a resposta de que tal prática ocasiona diversos impactos, principalmente negativos, no nosso espaço e em nossa sociedade. Por isso hoje encontramos diversas segmentações de turismo em que muitas contrapõem o turismo de massa, como por exemplo, o ecoturismo, o turismo de aventura, entre outras possibilidades. 
O turismo se depara com controvérsias e diversas questões dada sua intensidade e complexidade que às vezes é desdenhado. Envolvendo não somente as viagens, o turismo percorre pelas realizações pessoais dos que estão viajando, como a cultura, a história, as tradições e gastronomia, as paisagens, as belezas naturais, o sol, a praia e o campo, além de hotéis, de formas de hospedagem e entretenimento das mais criativas possíveis e de todo uma cadeia de equipamentos e serviços interconectada e em constante ampliação.

Cada vez mais, as pessoas têm buscado pelo turismo individualizado, que possibilite experiências únicas, vivências em lugares inusitados. Sendo assim, os turistas não se importam com a autenticidade, o que é valorizado é a experiência gerada, levando a entender que o aprendizado absorvido pelo turista não, necessariamente, está no original ou tradicional e sim, na experiência (GRABURN, 1967).

Ainda sob esse conceito, para Trigo (2013, p. 139), "Viagens são, literalmente, experiências, porém, podem ficar aquém do sentido e do significado de uma experiência mais profunda". Evidentemente, as expectativas são diferentes, tanto quanto os segmentos e tipos de turismo que existem pelo mundo.

Esta discussão ressalta a necessidade de compreender o turismo e o lazer "em sua complexidade histórica, social, política, cultural e semântica, explicitando suas condições de realização em nosso meio" (GOMES, 2004, p.140), já que ambos são vistos como minimizadores de impactos sociais e devem estar entre as prioridades do poder público para planejamento e execução de políticas públicas.

\subsection{POLÍTICAS DE LAZER E TURISMO E GESTÃO PÚBLICA MUNICIPAL}

Segundo Souza (2007, p. 68):

[...] não existe só uma definição de políticas públicas e nem a melhor definição. Ela pondera que política pública é "o campo do conhecimento que busca, ao mesmo tempo, colocar o 'governo em ação’ e/ou analisar essa ação (variável independente) e, quando necessário, propor mudanças no rumo ou curso dessas ações (variável dependente).

O Brasil é detentor de uma vasta coleção de riquezas paisagísticas e de diversidade biológica e cultural de alto interesse para o turismo doméstico e internacional, mais do que nunca necessita de instrumentos públicos legais, tanto de incentivo para um turismo mais responsável, como de controle para o ordenamento e uso equilibrado dos espaços turísticos (SALVATI, 2004). 
De acordo com o conceito de Cruz (2002), política de turismo pode ser entendida como:

Um conjunto de intenções, diretrizes e estratégias estabelecidas e/ou ações deliberadas, no âmbito do poder público, em virtude do objetivo geral de alcançar e/ou dar continuidade ao pleno desenvolvimento da atividade turística num dado território (CRUZ 2002, p. 40).

Segundo a mesma autora, no Brasil, duas políticas nacionais haviam sido instituídas a partir de um conjunto de ações, deliberadas pelo poder público, em torno do objetivo de ordenar o desenvolvimento da atividade turística. Uma delas, pelo Decreto-lei 55 de 18 de novembro de 1996, que define a Política Nacional de Turismo e cria o Conselho Nacional de Turismo - CNTur e a Empresa Brasileira de Turismo - EMBRATUR, sendo que a outra foi instituída em 1996, decorrente da Lei 8.181/91 e do Decreto 448/92.

Até o Decreto-lei 55/66, as políticas nacionais de turismo restringiam-se a aspectos parciais da atividade e não eram oficialmente reconhecidas como tal. Durante os vinte e quatro anos que separam o Decreto-lei 55/66 da Lei 8.181/91, outras políticas nacionais de turismo surgiram na forma de diplomas legais - normas instituídas no âmbito do direito, como leis, decretos, decretos-lei, resoluções, portarias, alvarás - com efeito regulador da atividade.

A Lei $\mathrm{n}^{\mathrm{o}} 11.771$ de 17 de setembro de 2008, dispõe sobre a Política Nacional de Turismo, que define as atribuições do Governo Federal no planejamento, desenvolvimento e estímulo ao setor turístico; revoga a Lei no 6.505, de 13 de dezembro de 1977, o Decreto-Lei no 2.294, de 21 de novembro de 1986, e dispositivos da Lei no 8.181, de 28 de março de 1991; e dá outras providências. Com o propósito de fomentar o turismo no Brasil e torná-lo um indutor da inclusão social, criou-se, o Plano Nacional do Turismo - PNT 2007-2010, a fim de consolidar o país como um dos principais destinos turísticos mundiais. O PNT é fruto do consenso de todos os segmentos turísticos envolvidos no objetivo comum de transformar a atividade em um importante mecanismo de melhoria do Brasil, fortalecendo o mercado interno, com ênfase no âmbito social do turismo.

Assim, segundo definição de Beni (2006, p. 91), política do turismo:

É um curso de ação calculado para alcançar objetivos, ou seja, direções gerais para o planejamento e a gestão do turismo baseadas em necessidades identificadas dentro de restrições de mercado e de recursos. Políticas são orientações específicas para a gestão diária do turismo, abrangendo os muitos aspectos operacionais da atividade. 
Portanto, sempre será necessário observar a teia de relações sociais, a estrutura institucional local, a migração e as consequências da sazonalidade regional na dinâmica e nas potencialidades do destino turístico das políticas de investimento e de geração de emprego e renda. Dessa forma, o planejamento estratégico deve estar atrelado às políticas de turismo e apoiar-se na participação social, bem como na equidade, intersetorialidade e sustentabilidade (BENI, 2006).

No país, as principais bases para o desenvolvimento do turismo são o Plano Nacional de Turismo e o Programa de Regionalização do Turismo. Segundo CARVALHO (2009), esses documentos orientam o turismo de forma estratégica e avaliam possíveis impactos que a atividade causa na economia, na sociedade e no meio ambiente. Sendo o turismo uma atividade que deve ser o foco do Estado, assim como da iniciativa privada e do terceiro setor, devendo ser planejado sob a sua importância no contexto atual.

O Plano Nacional de Turismo 2013-2016 expõe orientações no desenvolvimento turístico dos municípios, estados, iniciativa privada, terceiro setor e sociedade civil. Porem, o diagnóstico desse documento apresenta, principalmente, questões relacionadas com a economia, balanço de serviços, fluxo turístico, geração de emprego e competitividade. Já suas ações estão voltadas para captação de turistas, receita, comercialização e índice de competitividade (BRASIL, 2013). Esses dados evidenciam que a atividade turística trata-se, de maneira geral, de números e finanças.

Para Salvati (2004), os papéis de fomento e controle, a princípio, devem ser de responsabilidade do conjunto de agentes públicos e privados que atuam com o turismo. Porém cabe ao setor público a prerrogativa de ditar políticas orientadas para o planejamento e gestão do turismo em todos os níveis de governo, assim como para o setor privado, visando atender os diferentes níveis: Nacional, Federal, Estadual, Regional e Municipal.

É no âmbito municipal que o visitante entra em contato direto com a atividade turística e realiza suas práticas, e, portanto, são os organismos municipais de turismo que constituem uma das bases indispensáveis do processo e do desenvolvimento turístico.

Apesar do principal objetivo do Ministério do Turismo - MTur ser a descentralização, o poder público local necessita de auxílio e participação das instâncias federais e estaduais e dos demais atores sociais envolvidos no processo, como o setor privado, terceiro setor e comunidade local para conseguir desenvolver o turismo local.

Nesse sentido, vários são os instrumentos que podem ser criados e implementados em âmbito local para a concretização dos objetivos e ações explicitados. Dentre eles, alguns são clássicos e fundamentais: Planos Diretores e as Leis de Uso e Ocupação do Solo, tais 
legislações que objetivam ordenar o território de forma a garantir o desenvolvimento socioeconômico do município e a qualidade ambiental e de vida de seus habitantes (SALVATI, 2004).

O lazer, por sua vez, está previsto pela Constituição Brasileira, como qualquer outro direito do homem, como educação, saúde, trabalho, entre outros, encaixando-se dentro dos direitos sociais. Assim, diferentemente dos direitos civis e políticos, “[ [..] os direitos sociais permitem reduzir os excessos de desigualdade gerados pela sociedade de mercado e garantir um mínimo de bem-estar para todos" (MENICUCCI, 2006, 138).

Segundo Marcellino (2008, p. 12),

Na Constituição de 1988, o lazer consta do Título II, Capítulo II, Artigo $6^{\circ}$, como um dos direitos sociais: o tempo aparece em outras ocasiões mas só é tratado, quanto à formulação de ações, no Título VIII, Capítulo III, Seção III, Do Desporto, no Artigo 217 , no $3^{\circ}$ e último parágrafo do item IV - O poder público incentivará o lazer como forma de promoção social (grifo a expressão por considerá-la carregada de vícios assistencialistas e considerar que não dá conta do direito à felicidade, que sempre precisa de justificativas baseadas em critérios de "utilidade").

A partir da Constituição de 1988 e do cenário em que as divisões/secretarias das prefeituras municipais brasileiras se encontram, observa-se que o lazer em muitos casos é tratado de forma restritiva, sendo resumido em apenas um conteúdo, na maioria das vezes o esporte. Em outros casos tais departamentos tendem a "eleger" outro setor "[...]. Não são poucas, nos âmbitos federal, estadual e principalmente municipal, as Secretarias e Divisões de Esporte de Lazer, Recreação e Lazer, Cultura e Lazer, Turismo e Lazer” (MARCELLINO, 2007, p. 14). Mesmo os meios de comunicação de massa alimentam programações parciais ligadas somente a atividades de esportes, arte e as manifestações em espaços públicos.

Cheibub (2014) exalta que o direito social dificilmente consegue se distinguir dos demais direitos ou compará-lo em relação o grau de relevância para sobrevivência, mas que por outro lado, deve-se mensurar o lazer, como direito social, de igual forma a qualquer outro direito.

Uma visão limitada do conceito de lazer dificulta, cada vez mais, na inserção de ações específicas por parte do poder público, que possam proporcionar programas destinados a comunidade local e, consequentemente ao turista, que assegurem o direito social de todo cidadão. Ressalta-se aqui, a necessidade de se estabelecer o conceito de lazer antes de qualquer medida ser tomada, que o planejamento seja eficaz pelo todo do lazer e não somente por partes fragmentadas. 
Nesta perspectiva, Marcellino (1996) retrata a responsabilidade que administração pública, sobretudo a municipal, para com a gestão de espaços para o lazer. Segundo o autor, é imprescindível que nossos órgãos de governança estejam cientes dos riscos que tratam a questão do espaço, em especial do espaço de lazer, de acordo com a lógica do mercado e da especulação imobiliária. Essas condições favorecem um lazer restrito, de consumo rápido e possibilidades ínfimas, se comparado às suas potencialidades, que dificilmente haverá satisfação e, menos ainda, desenvolvimento pessoal e social dos praticantes; não se observa uma preocupação em facilitar a consciência e a troca de experiências entre pessoas, assim como o seu acesso aos equipamentos, ou proporcionar conforto e segurança no deslocamento pela cidade.

É necessário que o poder público municipal, através de políticas públicas e do desenvolvimento da cidadania social, planeje e execute suas ações voltadas primeiramente para a população local, para que esta possa se identificar com os espaços e equipamentos de lazer da cidade. Além disso, deve-se incentivar a participação da comunidade, promover a consciência para a obrigação comum e proporcionar o bem-estar coletivo. E em segundo plano seja pensado o turista. O turista tem que se sentir acolhido pela comunidade e a comunidade só fará esse papel acolhedor quando se sentir parte integrante das políticas municipais (CHEIBUB, 2014).

A partir da perspectiva do poder público, uma política de lazer deve ser estabelecida em, ao menos, três dimensões importantes e interligadas: o espaço, o tempo e a animação sociocultural (REQUIXA, 1980). Para que essas três dimensões de fato tenham efeito positivo na população e no lazer da cidade, cabe a administração pública municipal desenvolver políticas que democratizem os espaços destinados a tal atividade, além de conservá-los.

Segundo Marcellino (2007) uma política pública de lazer deve sempre disponibilizar a população e aos turistas os espaços patrimoniais e naturais existentes em condições adequadas de fruição. Quando a comunidade local se sentir atraída para estar em lugar agradável, bonito, tranquilo e bem cuidado, certamente o turista também vai se sentir.

A partir do momento em que um espaço é democratizado e se permite o acesso ao potencial histórico-cultural da cidade desperta-se o anseio do cidadão para que este se desloque de seu espaço para a realização de atividades culturais, apreciando e valorizando esse patrimônio, e desencadeando, dessa forma, um processo de sensibilização na comunidade local. Esse processo pode possibilitar um maior aprendizado e interesse sobre a própria história da cidade, bem como despertar o seu afeto, fazendo com que o cidadão projete o seu 
patrimônio e queira compartilhar com os visitantes essa aura, esse olhar não rotineiro (MOESCH, 2003).

De acordo com Requixa (1980), as diretrizes que regem uma política pública não devem se limitar à apenas atividades, mas que esta deve atender questões que abarquem a formação e a capacitação de quadros para atuação, de espaços e de equipamentos, bem como critérios de reordenação do tempo.

Assim, fica por responsabilidade da gestão pública estabelecer, em suas cidades, prioridades que visem o lazer, pensando em sua realidade local, suas demandas e desafios, como infraestrutura e espaços.

O espaço de lazer, por sua vez, é relevante por caracterizar-se como espaço de encontro humano, de convívio, de manifestação cultural, possível de ser aproveitada, mesmo com algumas ressalvas, pela atividade turística. O espaço para o lazer não deve ser pensando apenas na visão mercantilista, em que pode atrapalhar algumas iniciativas de preservação de espaços públicos, e neste sentido o lazer favorecia apenas o individualismo.

Neste sentido, cabem às prefeituras, secretarias e aos órgãos públicos de administração em geral, sobretudo em âmbito municipal, buscar soluções para realizar transformações e adaptações necessárias no espaço de lazer, de forma que a população seja envolvida no processo, seja levada em conta, a relação e apropriação que o cidadão estabelece com espaço urbano como um todo e, mais especificamente, com o espaço de lazer. E para que isso se viabilize, é necessário trabalhar com estratégias de ação que privilegiem a participação da população.

A partir destas considerações podemos compreender a importância de um lazer democrático, em que todos devem ter acesso. Esta compreensão nos permite explicar então o compromisso e a importância que o setor público possui em relação com a sua democratização. O lazer deve ser visto não apenas como uma expressão cultural, que em muitos discursos políticos serve apenas para retirar os jovens da marginalidade, mas sim como uma questão de cidadania, de saúde, de qualidade de vida.

Cabe salientar que a necessidade do lazer, não deve ser vista apenas como entretenimento possível de ser comercializado, mas sim ao como direito humano. Neste sentido, é destacado também a importância da gestão pública como principal mediadora desse processo de democratização (MARCELLINO, 1996).

Dessa forma, a gestão pública municipal assume a responsabilidade na administração desses espaços, pois estas instâncias estabelecem uma relação aproximada dos residentes, tendo assim a possibilidade de conhecer as necessidades pontuais e específicas do lugar. E de 
acordo com as políticas de municipalização e estatuto das cidades, que estabelecem uma autonomia às prefeituras por meio de uma gestão descentralizada, permitindo que dentro da prefeitura ocorra uma divisão interna, denominando órgãos/secretárias/divisões especificas para gestão de determinadas atividades de acordo com a necessidade do município precise (MARCELLINO, 1996).

Nos últimos anos tornou-se muito comum encontrar a gestão municipal do lazer se relacionando com a gestão de outras atividades, tais como esportes, cultura, educação e eventos. Atualmente o turismo entrou também nesta lógica, se tornando mais uma atividade que necessita de planejamento, gestão, espaços, infraestrutura, etc. De tal modo, as secretarias/divisões responsáveis por esses setores acabam recebendo o nome de diversos departamentos.

Se a gestão do lazer já se torna difícil por si só, tendo em vista sua subjetividade e todos os agentes produtores envolvidos, ao atribuirmos outras atividades a estas secretarias, como o turismo, o esporte, cultura, educação, ou eventos, vemos a complexidade que a gestão pública vem enfrentando.

Por outro lado, combinação do turismo e o lazer concede a oportunidade para as pessoas que não podem vivenciar, em seu dia a dia, experiências de controle, busca de paz social e qualidade de vida, em que esses elementos permitem com que entendamos por criação de significados a respeito do turismo, enquanto instrumento do lazer. Este que, por sua vez, é pressionado pelo jogo político e econômico, também trata de uma área fértil no campo da história e das ciências sociais.

Por fim, ressaltamos que existe uma precariedade nas políticas públicas governamentais e municipais e, que o lazer, enquanto difusor da participação social e cultural, pode ser visto como soluções para os diversos problemas das cidades e sua população.

Um espaço público que tem sido utilizado como uma alternativa de lazer no país, com baixo custo, são os balneários. Tais espaços necessitam de políticas públicas direcionadas para ações que envolvam os aspetos sociais e culturais do município onde está inserido.

\subsection{BALNEÁRIOS COMO ATRATIVOS DE LAZER}

Em meados do século XVIII surge na Europa o turismo em balneários. Incialmente os motivos que levavam as pessoas a buscar esse segmento turístico foram os tratamentos médicos por meio de terapias a partir de banho de mar. Quem sofria de alguma doença 
procurava médicos que indicassem lugares destinados à cura através da água (BRASIL, 2007).

Nesses ambientes onde o sol, o mar e sua salinidade, tinham como representatividade o restabelecimento físico e mental das populações mais nobres. Também ajudavam nesse processo a paisagem marítima e sua brisa como fomentadores do relaxamento e alívio. Contemplar esses lugares traziam para tais indivíduos uma paz interior que muitas vezes não se alcança por medicamentos.

Já no século XIX, a Europa transforma os espaços praianos em lugares com intuito mais social, principalmente nos países da Inglaterra, França, Itália e Espanha, tudo isso por meio dos spas, do iatismo, dos bailes e dos passeios à beira-mar. Concomitantemente, temos a industrialização que foi se expandido e evoluindo, melhorando também os sistemas de transporte. Esse processo facilitou o acesso às cidades litorâneas e o visitante já não é somente das classes mais nobres, todos os públicos começam a frequentar as praias. É nesse momento que as praias se popularizam (BRASIL, 2007).

De acordo com Santos Filho (2005), ainda no século XIX o lazer ganha destaque nos ambientes aquáticos. As praias do mediterrâneo passam a serem destinos turísticos em destaque na Europa, recebendo turistas de diversos países, mas que inicialmente continha um público mais elitista e, somente a partir da década de 1960 passa a receber um turismo mais massivo.

Nessa mesma década dois importantes acontecimentos devem ser considerados. O primeiro refere-se ao fluxo de turistas nas regiões litorâneas, considerado um fenômeno social, onde pessoas de diferentes lugares se encontravam para recrear-se e relaxar. E um segundo que é o fato de outros lugares também chamarem atenção por esse segmento turístico, já que os transportes estavam facilitando o acesso a tais lugares, como por exemplo, Acapulco (México), Viña Del Mar (Chile), Mar del Plata (Argentina), Punta Del Este (Uruguai) (SANTOS FILHO, 2005).

No ano de 2010, segundo a OMT - Organização Mundial do Turismo (2010), a região do Mediterrâneo, composta por um grupo de 24 países da Europa, África e Oriente Médio, foi considerada o principal destino turístico do mundo, tendo registrado anualmente quase 100 milhões de chegadas de turistas internacionais de sol e praia. A Espanha, em conjunto com a Itália, a Grécia, a França e a Turquia representam 85\% desse volume. No entanto, esses territórios turísticos costeiros tradicionais de proximidade como o Mediterrâneo (para os europeus), o Caribe (para os americanos), o Havaí (para americanos e japoneses) 
estão alcançando uma fase de maturidade ou saturação, em função da rapidez e facilidades da viagem.

Já o Brasil que além de ser detentor de uma costa litorânea imensa, com mais de 8mil km de extensão, também tem imensos rios, lagos e reservatórios com excelente qualidade de água espalhado por todo território nacional. É claro que há ressalvas quanto alguns ambientes aquáticos que nos dias de hoje, já não possuem boa qualidade de água, por conta do crescimento populacional nas áreas urbanas, como também o aumento das empresas, e, sobretudo, por falta de saneamento e controle das águas adequados.

Segundo Ribeiro (2011), no país, a expansão do turismo de sol e praia se consolidou nos anos 70, primeiramente com a construção de segundas residências no litoral. O segmento surge no Rio de Janeiro, na faixa de Copacabana, se expande para as outras áreas das regiões Sudeste e Sul e, posteriormente para todo o litoral brasileiro. Em sequência surgem no país os destinos com a proposta de cura, como na Europa, conhecidas como cidades termais que vislumbraram em suas águas de boa qualidade a oportunidade de se promover pelo e para o turismo. Algumas cidades ficaram conhecidas e ainda são visitadas por esse motivo, como é o caso de Poços de Caldas em Minas Gerais.

Esses destinos turísticos, que tinham como promessa a cura através das águas termais, também investiam nos cassinos como atrativos. Isso decorria sob o fato que os doentes viajam acompanhados e tais acompanhantes precisavam de distração. Então foram construídos hotéis luxuosos que possuíam, em seu interior, grandes cassinos. Todavia, com a proibição dessa atividade no Brasil, esses destinos tiveram uma queda brusca de turistas. Porém, os turistas continuaram a frequentar a cidade para desfrutarem das águas termais e das paisagens (BRASIL, 2007).

Nos anos de 2004 e 2006, o Plano Aquarela (2007) destacou que o lazer representou $70 \%$ das motivações para as viagens no Brasil.

Dentre o lazer, de modo geral, ainda com base nesses dois anos, os principais aspectos motivadores da visita ao Brasil foram as belezas naturais, a diversidade brasileira e o povo e a cultura popular, sendo o item praia marítima especificamente, representante de $31 \%$ e $37 \%$, respectivamente. Assim, estes itens são constantemente utilizados nas campanhas promocionais para sensibilizar os turistas para viajar ao Brasil. Na análise dos produtos ofertados pelo trade internacional em seus catálogos impressos, é possível identificar a liderança dos produtos do Segmento Sol e Praia como os mais ofertados na maioria dos países analisados, como Argentina, Chile, França e Portugal. Pesquisas sobre a demanda turística internacional13 apontam que 60,4\% dos turistas têm como motivação das viagens a lazer o Turismo de Sol e Praia (BRASIL, 2007, p 110). 
Confirmando essa informação, pesquisas realizadas pelos Hábitos de Consumo do Turismo do Brasileiro (2015) do (FIPE/MTur) ressaltaram que o brasileiro tem a predileção por roteiros de praias. A praia foi destaque dentre as principais opiniões, sobre a escolha de serviços e produtos turísticos. Dentre os clientes consultados no período da pesquisa - aqueles que compraram serviços de turismo em pacotes ou em partes nos últimos dois anos - 64\% e $64,9 \%$ elegeram como roteiro preferido as praias brasileiras, em 2007 e 2009, respectivamente. Dentre os motivos da escolha de um destino turístico, é interessante observar que a praia aparecia em primeiro lugar em 2007 com 31\%, seguida por beleza.

Por ter uma vasta variedade de opções de recursos hídricos, o Brasil consegue ofertar diferentes destinos aquáticos, em diferentes regiões brasileiras aos seus visitantes.

$\mathrm{Na}$ sociedade moderna, a relação das pessoas com água tem evidenciado a sua apropriação do perante a natureza, contudo a compreensão dessa relação deve exceder o entendimento limitado do sentido utilitarista da água, pois esta carrega consigo valores simbólicos, religiosos, culturais, místicos que percorreram por grande parte da cultura de muitos povos (DICTORO, 2017).

Já é de conhecimento que a água é um bem essencial à vida e, portanto, vital nas relações humanas. É um tema frequente nas discussões acerca de assuntos como sustentabilidade, impactos sociais, desenvolvimento urbano e qualidade de vida. Em geral, essas discussões levam a conscientizar as pessoas quanto aos usos desse bem vital, uma vez que, a utilização da água há muito não tem sido valorizada em suas diversas relações as pessoas. Ou seja, a sociedade faz uso da água em diferentes formas, durante séculos, mas pouco compreende, de fato, tal relacionamento, gerando resultados negativos (quantitativos e qualitativos) em nossa cultura e, sobretudo, em nosso meio ambiente.

Individualmente, cada pessoa tende a se posicionar, sentimentalmente, a respeito do meio onde vive e em especial, com o meio natural que está a sua volta. Esse processo se fortifica, por exemplo, com as paisagens que vemos e elegemos como nossas favoritas ou então que escolhemos para contemplar em nossos diversos momentos do dia a dia.

A relação do ser humano com o ambiente é a compreensão dos sentimentos que cada indivíduo desenvolve com a uma paisagem ou local e com todos os seus componentes, além das experiências com os mais diversos elementos da própria área. Sendo assim, o lazer desenvolve um relevante papel nesse relacionamento, como elemento cultural, e que percorre pelas gerações durante os anos e em todos os povos. Muitas das vezes elegemos os lugares ao ar livre para desenvolver uma atividade de lazer ou recreacional por conta do convívio com o 
meio natural, sua energia, pela tranquilidade e pela rotina cada desgastante nos centros urbanos.

Segundo Boullón (2004), a busca por lazer e recreação ao ar livre ou para consumir algum serviço recreativo da cidade atinge cerca de $20 \%$ da população urbana mundial. Mas espaços voltados a atender as necessidades recreativas da população, sobretudo as mais carentes, ainda são insuficientes na maioria das cidades.

Esse número se torna pequeno pelo fato de ser mal planejado. A maioria dos espaços voltados para o lazer nas cidades está localizada nos centros das cidades, muitas vezes, com restrita divulgação dos eventos que ali ocorrem e por serem taxados como santuários (Camargo, 1998). Esse fator impede que as pessoas que vivem em áreas periféricas, distantes do centro, consigam acesso a esses espaços por diversos motivos: falta de informação, localização, costume de frequentar eventos e atividades como as que são oferecidas e por não se sentirem pertencentes destes espaços.

No estado de São Paulo, essa relação próxima com os recursos hídricos se faz presente, por exemplo, nas Estâncias Turísticas de São Paulo, que ganhou entre suas quatro categorias, uma destinada a ela, que são as Estâncias balneárias, localizadas no litoral paulista.

É comum o brasileiro em suas férias viajar para destinos que contenham um recurso hídrico, seja ele um rio, um lago, cachoeira, lacustre ${ }^{2}$, ou mar. Aprendemos desde nossa infância, muito por culpa no nosso clima tropical e por nossas férias coincidirem com o período mais quente do ano, a apreciar as praias.

Um espaço de lazer comum às diversas classes sociais, que não discrimina classe, raça ou crença, e que agrada boa parte dos brasileiros é a praia. A costa litorânea do Brasil atrai, especialmente, nos períodos de férias, um grande público de visitantes para o litoral.

O litoral brasileiro é responsável por preencher grande parte da demanda de lazer e recreação das cidades costeiras, mas esse não é o mesmo cenário dos demais municípios, principalmente quando falamos dos grandes aglomerados urbanos, pois segundo Boullón (2004), os rios que percorrem esses municípios estão, na maioria das vezes, em condições inadequadas ao banho ou para a recreação. Alguns desses rios sofreram alteração drásticas quanto ao seu curso, recebendo canalização, já outros estão totalmente poluídos pelas indústrias, resíduos sólidos e efluentes domésticos.

Por outro lado, uma grande modificação nos ambientes aquáticos, tem favorecido as práticas de lazer, recreação e turismo que nas inúmeras represas construídas no Brasil, com a

\footnotetext{
${ }^{2}$ Referente a lago.
} 
finalidade de geração de energia elétrica vêm sendo exploradas para recreação e turismo (JULIO Jr. et al., 2005). No Estado de São Paulo ocorreram três grandes transformações. Que foram nos rios Tietê, Grande e Paranapanema. Ambos se tornaram uma sequência de reservatórios em "cascata" (HENRY et al., 2006; TUNDISI et al., 2002) alterando a geografia dessas bacias hidrográficas e resultando em novos ecossistemas e novas paisagens. Nesses lagos construídos, surgiram praias que são aproveitadas para o desenvolvimento de atividades recreativas que atraem tanto a população local quanto turistas.

A prática de turismo e lazer em lagos e reservatórios encontram-se em processo de desenvolvimento em alguns dos principais reservatórios brasileiros, porém carece de definição de política e estratégia de uso racional do recurso hídrico como instrumento de ofertar lazer de fácil acesso à sociedade devido seu custo (ANA, 2005).

A transformação desses recursos hídricos em represas em primeiro momento atenderia a demanda energética do país, mas também deram origem as novas paisagens, formando espelho d'água, ilhas, praias e bancos de areias. Esses locais foram transformados em área de lazer e passaram a ser considerados potenciais turísticos nas regiões e, consequentemente se tornaram relevantes na prática do turismo em contato com a natureza (ROMERO; GRANADO, 2014).

Segundo Branco e Rocha (1977) as represas artificiais proporcionam uma imagem nova e diferente à paisagem regional, que com o decorrer do tempo transformaram-se em áreas de lazer para a população paulistana.

Também em São Paulo, o rio Paraná, um dos rios mais limpos e um dos maiores do estado, abriga algumas hidrelétricas no seu percurso. O represamento dessas hidrelétricas também é utilizado para fins de lazer e de turismo, em formato de balneários municipais. As prefeituras das cidades onde há o represamento de águas desse rio, têm buscado, por meio dos balneários, atrair visitantes para o município a fim de movimentar a economia.

De acordo com Ribeiro e Granado (2015), mesmo não sendo a principal razão para a transformação desses espaços em balneários, o que se conquista são espaços de lazer, recreação, atividades físicas, sociabilidade, eventos culturais, descanso e, sobretudo um sentimento de pertencimento. Quando a população local se identifica com algum lugar de seu município, este se torna um patrimônio particular e referência de prazer para o morador, sinônimo de tranquilidade e diversão.

O fato de ser uma atividade de baixo custo e que pode envolver muitas pessoas, familiares e amigos, também influencia na escolha pelo lazer nesses ambientes. 
No caso do rio Paraná, por estar localizado entre os estados de São Paulo e Mato Grosso do Sul, facilita a sua visitação para as regiões do oeste paulista e leste/sul sul-matogrossense, por estarem distantes da costa litorânea.

Os balneários, mesmo que menores em extensão e com água doce, muito se parecem com as praias do litoral brasileiro em infraestrutura de lazer e para o turismo. Apresentam quadras esportivas, lanchonetes, espaço para alongamento ao ar livre, salva-vidas, espaço para campings, estacionamento, entre outros.

Mais do que o entendimento de lazer ou turismo para a comunidade local, o mais importante é sua identificação com ele. Quando a população se sente identificada com algum atrativo turístico ou um espaço público, este ganha força para se desenvolver. É claro que ainda depende do setor público para abarcá-lo com políticas e iniciativas de fomento, mas a aceitação e participação da população é imprescindível para dar o inicio. 


\section{PRAIAS DO INTERIOR PAULISTA: O CASO DE PRESIDENTE EPITÁCIO E ROSANA}

Essa seção destina-se a apresenta as cidades de Presidente Epitácio e Rosana, com seu contexto histórico, sua geografia, economia, distância em relação às principais cidades do seu entorno e também, a secretaria/divisão responsável pelos setores de turismo e lazer, seus sites institucionais e planos, diretor e diretor de turismo.

\subsection{PRESIDENTE EPITÁCIO: A JOIA RIBEIRINHA}

Nesse momento serão apresentadas as informações referentes ao município de Presidente Epitácio.

Presidente Epitácio é um município do interior paulista localizado no extremo oeste do estado, na região do Pontal do Paranapanema, que é composta por 32 cidades. Faz divisa com o Mato Grosso do Sul e tem como municípios limítrofes Panorama Caiuá, Marabá Paulista e Teodoro Sampaio (PRESIDENTE EPITÁCIO, 2017). De acordo com o Instituto Brasileiro de Geografia e Estatística - IBGE, o município possui área territorial de aproximadamente 1.260,281 km, e população estimada (censo de 2016) em 43.718 habitantes (IBGE, 2017). No que tange a economia base de Presidente Epitácio, esta está pautada na indústria, agropecuária, comércio e prestação de serviços. É neste último que o turismo e o lazer estão inseridos.

Situado às margens do Reservatório da Usina Hidrelétrica Engenheiro Sérgio Motta, no rio Paraná, o segundo maior rio do Brasil, Presidente Epitácio tem, predominantemente, uma configuração topográfica plana, sendo os topos extensos, suaves, ondulados e cobertos por vegetação rasteira (CAMARGO; SILVA, 2005). Localizada na rodovia SP-613, Km 78, a barragem, no município de Presidente Epitácio, no rio Paraná, é uma das mais extensas do Brasil, com 10.186.20 metros de comprimento e seu reservatório possui $1.150 \mathrm{Km}^{2}$ (PRESIDENTE EPITÁCIO, 2017).

A temperatura média do município é de $26^{\circ} \mathrm{C}$, oscilando entre $40^{\circ} \mathrm{C}$ máxima e $10^{\circ} \mathrm{C}$ mínima, fazendo jus à maioria dos dias ensolarados, predominantes na região e, também, ao clima tropical (quente e úmido) do país. Já as chuvas incidem, com maior frequência, nos meses de janeiro e fevereiro tendo a precipitação pluviométrica anual de $1.430 \mathrm{~mm}$ e a umidade relativa do ar de $80 \%$ (GODOY, 2002).

Outro ponto de referência geográfica que Presidente Epitácio possui é a Bacia Platina, também conhecida como Bacia do Prata, que está entre as maiores e mais importantes bacias do Brasil. 


\begin{abstract}
A Bacia Platina é formada pelos rios Paraná, Paraguai e Uruguai. O rio Paraná é essencialmente de Planalto, apresentando inúmeras cachoeiras e um elevado potencial hidráulico, sendo este rio o de maior aproveitamento hidroelétrico no Brasil (NAKATA 1979, p.118).
\end{abstract}

Com relação às estradas que interligam Presidente Epitácio com municípios maiores e com as capitais dos estados que tem proximidade, permite-se três possibilidades. A primeira, e principal, é a rodovia Raposo Tavares (SP-280) que faz conexão com cidades de Presidente Prudente, Assis, Ourinhos, Sorocaba e com a capital do estado de São Paulo. A segunda via de acesso, Euclides Figueiredo (SP-563), direciona-se ao norte do estado de São Paulo e para os estados de Minas Gerais e Goiás, interligando-se pelas cidades de AndradinaSP, Ilha Solteira - SP, Rio Verde - GO, São Luís de Montes Belos - GO, Campina Verde MG, Patos de Minas - MG e com as capitais dos respectivos estados. A terceira é a rodovia BR 267, que interliga o município com o estado do Mato Grosso do Sul, sua capital e como os municípios de Bataguassu e Nova Alvorada do Sul, ambos em MS. O quadro 1 apresenta as distâncias em quilômetros de Presidente Epitácio com as principais cidades da região. 


\begin{tabular}{|l|c|}
\hline \multicolumn{1}{|c|}{ MUNICÍPIO } & DISTÂNCIA EM \\
\hline Presidente Prudente & 93 \\
\hline Assis & 214 \\
\hline Ourinhos & 281 \\
\hline Sorocaba & 581 \\
\hline Ilha Solteira & 238 \\
\hline Andradina & 162 \\
\hline São Paulo & 644 \\
\hline Londrina & 249 \\
\hline Curitiba & 638 \\
\hline Rio Verde & 603 \\
\hline São Luís de Montes & \\
\hline Belos & 798 \\
\hline Goiânia & 832 \\
\hline Campina Verde & 463 \\
\hline Patos de Minas & 845 \\
\hline Belo Horizonte & 1137 \\
\hline Bataguassu & 36 \\
\hline Nova Alvorada do & 372 \\
\hline Sul & \\
\hline Campo Grande & KM \\
\hline - Distancias & \\
\hline
\end{tabular}

\section{ESTADOS DE \\ REFERÊNCIA}

\begin{tabular}{|l|l|}
\hline & São Paulo \\
\hline & Paraná \\
Goiás \\
Minas Gerais \\
\hline
\end{tabular}

Tabela 1 - Distâncias de Presidente Epitácio para as principais e, mais próximas, cidades e capitais (Fonte: Roberta Dias de Moraes Ribeiro 2017).

A história de Presidente Epitácio teve origem na necessidade, no início do século $\mathrm{XX}$, da construção de uma estrada de rodagem que ligasse o trecho compreendido entre o "sertão desconhecido" e desabitado desta parte do Estado de São Paulo, com o sul de Mato Grosso, atual Mato Grosso do Sul (GODOY, 2002, p. 17).

Inicialmente, a região era utilizada como passagem de boiadas, vindas do Mato Grosso para São Paulo e com o passar dos anos, transformou-se em corredor das madeiras extraídas. Essa mudança ocorreu no ano de 1949, atraiu cada vez mais pessoas e, consequentemente, interesses, auxiliando para ascensão do lugar em município em 27 de março do mesmo ano. 
De acordo com Camargo e Silva (2005), o nome Presidente Epitácio deve-se à homenagem que a maioria dos municípios da Alta Sorocabana prestaram aos presidentes da República do Brasil, no caso desse município o homenageado foi Epitácio Pessoa, Presidente da República que governou o Brasil entre os anos de 1919 e 1922. Desde 1972, a cidade é conhecida como “joia Ribeirinha”, que significa joia lapidada pelas águas e praias do rio Paraná. Por conta de sua localização, principalmente em função do rio Paraná, o município possui belas paisagens, e esse foi um dos principais motivos e promessas para que Presidente Epitácio prosperasse economicamente.

É por conta do rio Paraná, também, que foram incentivadas atividades de lazer e recreação à comunidade local e aos turistas, criando uma harmonia entre os habitantes da cidade com o Rio, como se eles se sentissem pertencentes àquele local.

Conforme Camargo e Silva (2005), o turismo, desde a década de 1990, demonstrou ser um importante vetor econômico para a cidade, principalmente pelo fato de que, nessa mesma época, Presidente Epitácio foi nomeada como Estância turística, de acordo com a Lei $\mathrm{n}^{\text {o }} 6.956$ de 20 de julho de 1990, como confirma Bomfim (2006, p. 39):

Transformada em Estância Turística, em 20 de julho de 1990, através da Lei ${ }^{\circ}$ 6956, por seus recursos naturais e atrativos históricos, culturais e artísticos, passou a contar com o apoio financeiro do Departamento de Apoio ao Desenvolvimento das Estâncias (DADE), órgão vinculado à época à Secretaria Estadual de Esporte e Turismo.

A partir desta data, a cidade de Presidente Epitácio passou a contar com o apoio financeiro do Departamento de Apoio ao Desenvolvimento das Estâncias (DADE), que atualmente é nomeado como DADETUR (SECRETARIA DE TURISMO DO ESTADO DE SÃO PAULO, 2017), órgão vinculado à Secretaria Estadual de Turismo.

O município dispõe de cenários deslumbrantes emoldurados pelo rio-lago Paraná, privilegiada localização e atividades econômicas atreladas a pesca e a agropecuária. Tais atividades determinam e propiciam relações específicas tanto sociais como em relação ao meio ambiente, garantindo tranquilidade e sossego.

Esse modo de vida, associado aos aspectos geográficos e paisagísticos em que se insere, representa também um atrativo turístico. Entretanto, para que isso ocorra de maneira eficaz, é primordial que a atividade seja norteada por estratégias, diretrizes e políticas consistentes, decorrentes de um planejamento bem estruturado, principalmente, quando 
considerado que diversos espaços estão sendo construídos e remodelados para o desenvolvimento da atividade turística e para o lazer.

Os principais atrativos turísticos de Presidente Epitácio estão relacionados direta ou indiretamente, com o recurso hídrico da cidade, o lago no rio Paraná. Sendo assim, estão situados em sua proximidade. Por conseguinte, o Município vem confirmando sua vocação turística a partir da reestruturação de seu espaço, buscando a construção de novos ambientes específicos para o lazer. Porém, como afirma Bomfim (2006) deve se pensar, obrigatoriedade, em um planejamento turístico responsável para com os recursos naturais, para que a atividade se desenvolva de forma contínua e integrada, sem causar prejuízos ou danos, como a destruição dos valores ou descaracterização dos traços identitários, que o tornam único.

\subsubsection{Parque O Figueiral}

Na década de 1998 o rio Paraná sofreu grandes alterações, em virtude da construção do lago da usina hidrelétrica Engenheiro Sérgio Mota, operado pela Companhia Energética de São Paulo - CESP. Com essa construção, a cidade e seus arredores perderam grande parte de seu território, desaparecendo inclusive, áreas de práticas de lazer e turismo (CAMARGO; SILVA, 2005).

Ainda segundo os mesmos autores, o enchimento do lago da usina hidrelétrica nessa região ocasionou no desaparecimento de diversas ilhas. Na cidade de Presidente Epitácio, por exemplo, foram aproximadamente, trinta ilhas que ficaram submersas. Antes da criação dos reservatórios da CESP, esses ambientes aquáticos possuíam movimento de fluxo de turistas que disfrutavam de suas praias "isoladas".

Além disso, outro local importante para o lazer que atraia o maior fluxo turístico do Município desapareceu com a subida das águas, foi o parque antigo Parque Figueiral. Por conta de suas formas físicas naturais e da proximidade com o rio, o Parque era muito apreciado e visitado pela comunidade local e por turistas. Antes de tal perda, o Parque situava-se na barranca do rio Paraná, a três quilômetros do centro da cidade, era dotado de infraestrutura como: barracas, lanchonetes, área de camping, chuveiros e estacionamento (PRESIDENTE EPITÁCIO, 2017).

De acordo com dados apresentados por Camargo e Silva (2005), um novo Parque Figueiral foi construído em substituição ao antigo, agora com o nome O Figueiral. O novo Parque situa-se às margens do lago formado no rio Paraná, mas este está cerca de sete quilômetros do centro da cidade. Após a perda significativa de áreas do Município pela criação desse extenso lago artificial, A CESP começou a construir novos espaços com a meta 
de oferecer lazer e entretenimento à população, como forma de mitigação dos impactos socioambientais provocados.

O Parque O Figueiral atual, também conta com infraestrutura para atender seus visitantes, tais como: praia artificial, área de camping e de pesca, mirantes, lanchonetes, palco para shows, quadras poliesportivas, atracadouros e rampas para barcos. Ou seja, o novo Parque Figueiral oferece infraestrutura e equipamentos voltados para prática de esportes e de lazer (CAMARGO; SILVA, 2005).

Por outro lado, com a formação do grande lago formou-se um novo visual, que permitiu o incremento de diversas atividades náuticas, como pôde ser constatada, mediante o aumento das ofertas para o turismo de pesca, regata fluvial e demais esportes náuticos, como o projeto Navegar/Navega São Paulo (PRESIDENTE EPITÁCIO, 2017b).

Com a transformação do espaço que ocorreu nessa região, Camargo e Silva (2005), destacam a necessidade uma maior e melhor avaliação e análise quanto ao "fazer turístico", apontando para os benefícios e malefícios de tal instalação nessa localidade. A atividade quando esta não está atrelada às questões históricas e culturas, não valoriza suas características fundamentais, e pode, dentro do novo contexto sócio geográfico, fazer com que a população nativa não se sentir pertencente ao local. Dessa forma, destaca-se a importância da inserção da comunidade local no desenvolvimento da atividade turística e na modificação do seu espaço, por meio de um processo participativo.

\subsubsection{As Secretarias de Turismo e Cultura e a de Esportes e Educação}

A Secretaria Municipal de Turismo e Cultura da Estância de Presidente Epitácio, possui um secretário de turismo e quatro funcionários que completam a equipe. Igualmente ocorre na Secretaria de Esportes e Educação.

Ao investigar o site da Prefeitura Municipal de Presidente Epitácio, vemos que o destaque da cidade é o Rio Paraná. O site contempla eventos de diferentes cunhos sociais, solidários, políticos e esportivos. Porém, quando se trata de atrativos turístico, o Parque O Figueiral é o foco para o turismo.

Existe no site, uma repartição destinada ao turismo e cultura do município. Lá contém informações históricas, geográficas, o hino, símbolos e alguns vídeos promocionais. Além disso, nessa mesma repartição, há um setor com os eventos da cidade. Não existem grandes quantidades de fotos do município e nem informações sobre os segmentos turísticos que ocorrem em Presidente Epitácio. 
O site possui um espaço para cada secretaria, contendo informações pessoais do secretário, como sua formação, por exemplo, o contato do secretário e também, a missão da secretaria. O que se destaca na missão da Secretaria de Turismo e Cultura é que os itens pautados são voltados quase que exclusivamente para o lado cultural. Os artesanatos aparecem duas vezes dentre os oito itens, diferenciados em regional e municipal. A história e sua conservação também são consideradas nesse espaço, além das funções das funções correlatas pelo Chefe do Poder Executivo.

Um dos oito itens trata-se de "agilizar mecanismos para o desenvolvimento dos serviços inerentes à manutenção dos próprios necessários para o desenvolvimento das ações turísticas, esportivas e culturais" (ROSANA, s/p, 2017), que é a única referência de turismo feita entre os itens mencionados na missão da secretaria.

Em nenhum local do site, encontramos referência à palavra lazer. Ressalta-se aqui, que todas as secretarias foram analisadas e em nenhum momento foi encontrada.

Presidente Epitácio não possui um Plano Diretor de Turismo, portanto nos limitamos a analisar o Plano Diretor da cidade. Este por sua vez, contempla a palavra lazer quinze vezes, sendo que dez fazem referência ao esporte e as práticas esportivas. Duas delas fazem referência a economia do município, duas referem-se a cultura e a última sobre funções sociais.

Por se tratar de uma Estância Turística, esperávamos encontrar mais informações sobre o turismo do local, seus atrativos, acessos, infraestrutura. Contudo essas informações não estão disponíveis nem no site da Prefeitura e nem no Plano Diretor. Nesse segundo documento, muito provavelmente por conta de não ser um documento específico de turismo, não aborda questões aprofundadas sobre o turismo, apenas o cita para esclarecer o funcionamento de algumas atividades da cidade.

A falta de informações no site e no Plano Diretor denota o quão superficial é a relação do lazer com um município denominado estância. Demonstra ainda, o quão ele não é priorizado nas políticas municipais e menos ainda nas ações dos governantes de âmbito municipal.

\subsection{ROSANA: AQUI COMEÇA SÃO PAULO}

Nesse momento serão apresentadas as informações referentes ao município de Rosana.

Rosana é um município que está situado na região do Pontal do Paranapanema, no extremo oeste paulista, no qual faz divisa com os estados de Mato Grosso do Sul, ao norte, e 
Paraná, ao Sul, formando uma tríplice divisa. As cidades limítrofes são: Euclides da Cunha Paulista, Teodoro Sampaio, Anaurilândia, Batayporã, Diamante do Norte, Marilena e Nova Londrina.

Segundo as informações do IBGE (2017), a população estimada do município é de 19.691 habitantes (censo de 2016) e possui $744.011 \mathrm{~km}^{2}$ de extensão territorial. A economia da cidade está pautada, principalmente na prestação de serviços e do comércio, como aponta o Plano Diretor de Desenvolvimento Turístico Municipal de Rosana (2015).

O município conta, também, com um distrito, cuja origem está intimamente ligada à construção e ao funcionamento da U.H.E - Usina Hidrelétrica Engenheiro Sérgio Motta, o qual foi criado com a finalidade principal de abrigar as famílias dos trabalhadores desta U.H.E, denominado Primavera. Este lugar se tornou distrito de Rosana, conforme Lei Municipal n. ${ }^{\circ} 215$ de 08 de abril de 1994, e está distante da sede, aproximadamente $12 \mathrm{~km}$.

A principal via de acesso do município é a Rodovia Arlindo Bettio SP-613 que liga Rosana ao seu distrito Primavera. É por essa rodovia, também, que se faz conexão com os estados e suas capitais de divisa com Rosana. Para São Paulo utiliza-se a rodovia BR-374 (Castelo Branco), que interliga Rosana às cidades de Presidente Prudente, Assis, Sorocaba e a capital do estado. Para o estado do Paraná, é a rodovia PR-557 para fazer ligação com as cidades de Paranavaí, Maringá e Curitiba. Já para o estado de Mato Grosso do Sul, a rodovia utilizada é a BR-376, que passa por Nova Andradina, Nova Alvorada do Sul e Campo Grande. O quadro 2 apresenta as distâncias em quilômetros de Rosana com as principais cidades da região. 


\begin{tabular}{|l|c|}
\hline \multicolumn{1}{|c|}{ MUNICÍPIO } & $\begin{array}{c}\text { DISTÂNCIA EM } \\
\text { KM }\end{array}$ \\
\hline Teodoro Sampaio & 95 \\
\hline Presidente Prudente & 231 \\
\hline Assis & 317 \\
\hline Sorocaba & 684 \\
\hline São Paulo & 748 \\
\hline Nova Londrina & 50 \\
\hline Paranavaí & 131 \\
\hline Maringá & 201 \\
\hline Curitiba & 547 \\
\hline Nova Andradina & 87 \\
\hline Nova Alvorada do Sul & 268 \\
\hline Campo Grande & 384 \\
\hline
\end{tabular}

ESTADOS DE

REFERÊNCIA

\begin{tabular}{|l|l|}
\hline & São Paulo \\
& Paraná \\
\hline & Mato Grosso do Sul
\end{tabular}

Tabela 2 - Distâncias de Rosana para as principais e, mais próximas, cidades e capitais (Fonte: Roberta Dias de Moraes Ribeiro, 2017).

A temperatura média anual do município é de $23^{\circ} \mathrm{C}$, sendo a variabilidade entre $13^{\circ} \mathrm{C}$ e $40^{\circ} \mathrm{C}$, com características de climas tropical e subtropical, ou seja, os meses de maiores temperaturas são também, os meses com maior ocorrência de chuvas, dezembro, janeiro e fevereiro. A pluviosidade média mensal é de $130 \mathrm{~mm}$ e em $70 \%$ a umidade relativa do ar (PLANDO DIRETOR DE DESENVOLVIMENTO TURÍSTICO MUNICIPAL DE ROSANA, 2015).

Assim como Presidente Epitácio, Rosana está localizada as margens do rio Paraná, contudo encontra-se à jusante da barragem, sendo banhada, portanto, por águas correntes. Aproveitando-se dessa riqueza e beleza natural que é o Rio Paraná, sua proximidade com a cidade e o clima quente, a Prefeitura Municipal teve a iniciativa de criar o Balneário Municipal de Rosana, como área de lazer e como possibilidade de atrair turistas.

O município teve origem na construção da Estrada de Ferro Sorocabana, na parte que interligaria Presidente Prudente ao Rio Paraná, perto de sua confluência com o Rio Paranapanema, chegando a ser cogitado que essa ferrovia chegasse ao estado do Mato Grosso do Sul, porém a obra não foi concluída. A FEPASA - Ferrovia Paulista, empresa responsável pelo andamento da obra do ramal, chegou a construir sua sede administrativa no distrito de 
Rosana, Primavera, e aterrou grande parte do caminho que a estrada de ferro teria se tivesse sido concluída (PLANDO DIRETOR DE DESENVOLVIMENTO TURÍsTICO MUNICIPAL DE ROSANA, 2015).

Assim, em meados da década de 1950, a empresa Camargo Correia, responsável pela ferrovia, criou o município de Rosana-SP, que até meados de 1965 pertenceu a Presidente Epitácio, quando passou a integrar Teodoro Sampaio (ROSANA, 2017).

\begin{abstract}
A cidade de Rosana já pertenceu ao município de Presidente Epitácio (cidade que dista cerca de $210 \mathrm{~km}$ de Rosana) até 1965, onde fora criado o município de Teodoro Sampaio e Rosana uniu-se a este. Passados 26 anos, através de um plebiscito, Rosana se emancipa de Teodoro Sampaio e se eleva a município no ano de 1990, através da Lei $\mathrm{n}^{\circ}$ 6.645. O primeiro prefeito a tomar posse no então emancipado município de Rosana, foi Jurandir Pinheiro, no ano de 1993 (PLANDO DIRETOR DE DESENVOLVIMENTO TURÍSTICO MUNICIPAL DE ROSANA, 2015, 2015, p. 20).
\end{abstract}

O nome dado ao município foi uma homenagem a uma das filhas de um fazendeiro da região, Sr. Sebastião Camargo, que também era o principal dono da empreiteira Camargo Correia.

Já o Distrito de Primavera, foi construído com o objetivo de alojar os trabalhadores das duas grandes obras instauradas no atual município de Rosana, uma no rio Paraná, na divisa com o estado do Mato Grosso do Sul e outra no rio Paranapanema, na divisa do estado do Paraná, a Companhia Energética de São Paulo - CESP. O nome, Primavera, se deu por conta de sua inauguração ter ocorrido no mês de setembro de 1970, mês de referência à estação do ano primavera. Primavera se tornou o núcleo urbano de Rosana e a parte administrativa de Rosana, foi um local planejado para alocar os diferentes tipos de funcionários que operavam na usina.

\footnotetext{
O distrito de Primavera foi planejado. Desenhado em formato de barco, onde suas ruas onduladas representam o movimento das águas. Em sua construção pensou-se em vários detalhes como: tipos diferentes de residências (de acordo com a função que o trabalhador exercia na obra), arborização natural, hospital próprio, dois clubes de lazer, espaços públicos entre quadras residenciais com áreas de lazer em diferentes regiões da cidade, escolas, comércio, dentre outros detalhes que garantiam o conforto dos moradores da cidade inaugurada em setembro de 1980 (PLANDO DIRETOR DE DESENVOLVIMENTO TURÍSTICO MUNICIPAL DE ROSANA, 2015, 2015, p. 21).
}

De acordo com o Plano Diretor de Desenvolvimento Turístico Municipal de Rosana (2015), a usina Engenheiro Sérgio Motta, antes de receber esse nome era conhecida como porto Primavera, e até hoje há pessoas que se referem a ela com esse nome. Existem até citações em mapas oficiais com o nome antigo. 
Com relação à hidrografia do município, Rosana é banhada por dois grandes rios Paranapanema e Paraná. Dois grandes representantes do estado de São Paulo. O rio Paranapanema, tem como característica uma coloração mais amarronzada, porém é um dos rios menos poluídos do estado. O rio Paraná é o segundo maior rio da América do Sul, nasce no estado de Minas Gerais e vai até o Rio Iguaçu no estado do Paraná, com uma extensão de aproximadamente 4.880 quilômetros, garantindo a sétima posição de rio mais extenso do mundo e também, tem como característica água de boa qualidade, além de sua coloração mais azulada e límpida (ROSANA, 2017).

Segundo o Plano Diretor de Desenvolvimento Turístico Municipal de Rosana (2015), ambos os rios, Paranapanema e Paraná, se encontram no município de Rosana, perto ao marco zero do estado de São Paulo, também localizado no município e que se configura um importante atrativo turístico de Rosana. Por suas águas mais límpidas e com coloração mais azulada, é no rio Paraná que ocorrem a maioria das atividades de recreação, lazer e as turísticas e foi em nesse rio que a prefeitura municipal de Rosana construiu o Balneário Municipal de Rosana próximo ao centro da cidade.

\subsubsection{O Balneário Municipal de Rosana}

O Balneário Municipal de Rosana é o principal espaço utilizado para lazer e recreação pela população local e visitantes. Essa área de lazer foi inaugurada em meados de 1998 (ROSANA, 2017). O local possui infraestrutura para quem quer se divertir. Nele existem lanchonetes, área de camping, quadras de areia, campo de futebol, quiosques, sanitários, barco salva vidas, boias de limite de segurança, placas com informações aos turistas e segurança da Prefeitura Municipal.

É no Balneário que ocorrem os eventos da cidade promovidos pela Prefeitura Municipal como carnaval, ano novo, atividades esportivas de $1^{\circ}$ de maio, shows e eventos em geral. A população residente tanto de Rosana quanto de Primavera se identifica com o local e procura o espaço para seus momentos de lazer e também para pesca, esportiva, profissional e para o próprio sustento (como é o caso da comunidade ribeirinha).

De acordo com o site institucional da cidade, Rosana (2017), em geral é a Divisão de Municipal de Turismo, Eventos e Cultura que utiliza o espaço para promover o lazer e o turismo da cidade, mas a Divisão Municipal de Eventos também busca usar o balneário para promover os campeonatos (municipais e regionais) de futebol e vôlei de areia.

É de grande valia ressaltar que a comunidade local tem como costume frequentar o balneário, principalmente aos finais de semana, em seu momento de lazer, muitas vezes para 
acampar nos locais de camping. Por outro lado, mesmo tendo cidades em seu entorno que possuem balneários municipais, existem frequentadores de outros municípios que preferem ir até Rosana para vivenciar seu momento de lazer, pois o Balneário Municipal é um dos mais equipados, limpo e com maior área de acampamento, quando comparados com o dos demais municípios da região.

\subsubsection{A Divisão Municipal de Esportes, Turismo e Cultura.}

A Divisão Municipal de Turismo, Eventos e Cultura do município de Rosana, é composta por um diretor responsável pelo setor, e por uma equipe de quatro funcionários.

O site da Prefeitura Municipal destaca em sua página, os recursos naturais da cidade como seus principais atrativos turísticos, incentivando o turismo, principalmente, de pesca. Esse incentivo é cometido pelos rios que banham a cidade, Paraná e Paranapanema, mas é o Balneário Municipal que ganha destaque das suas fotos e propagandas.

Os dois segmentos turísticos apresentados no site são o de turismo de pesca e o turismo rural $^{3}$. Ao analisar o que é apresentado no site, percebemos que o turismo rural ainda é incipiente na região, pois não há muitas informações sobre o assunto, há apenas uma exposição breve sobre o que pode se encontrar ao praticar esse segmento, como por exemplo, boa hospitalidade e contato com a natureza. O turismo de pesca, por outro lado é referido como algo praticado com frequência no município, mesmo que o site apresente poucas informações do como é praticado ou como é realizado, o próprio texto menciona que é um segmento popular para a região.

Como é divida com os setores de esportes e cultura, a Divisão também faz publicidade de alguns pontos de referencial cultural do município, como é o caso do Cine Teatro Casa da Cultura, local destinado para apresentações culturais, teatros, palestras, eventos, entre outros. Esse espaço está localizado no centro de Primavera, com fácil acesso a toda população.

Até o ano de 2016, gestão passada, o nome da Divisão era "Divisão de Turismo, Eventos e Cultura e nesse ano, 2017, passou a integrar o esporte em seu nome”. O setor de Eventos não está evidenciado em nenhuma divisão específica, mas está presente em uma repartição do site destinada as notícias. Nessa repartição há um espaço destinado à “eventos e

\footnotetext{
${ }^{3} \mathrm{O}$ turismo rural é fomentado na região por conta dos assentamentos rurais presentes no entorno dos municípios pesquisados. Os assentamentos estão localizados às margens dos rios Paranapanema e Paraná e têm ofertado aos seus visitantes passeios a cavalo, artesanatos e doces e comidas caseiras, além de paisagens naturais, como forma de atrair turistas.
} 
esportes", enquanto que o turismo, nessa repartição, está apenas atrelado à cultura, diferente da proposta do nome da divisão.

Quando analisamos a palavra lazer no site municipal, observamos que esta está inerente a palavra esporte. O lazer aparece três vezes durante as propostas municipais e nos objetivos das divisões. Em ambas às vezes está relacionada à prática de esportes como forma de integração social e uso de espaços públicos. E em uma delas a palavra aparece no setor de indústria e comércio, enfatizando a necessidade de se fomentar, o que é tratado no site, a indústria turística na cidade.

No ano de 2015, a divisão em questão elaborou o PDDTMR - Plano Diretor de Desenvolvimento Turístico do Município de Rosana - SP, com a pretensão de candidatar-se ao MIT - Município de Interesse Turístico, e assim, um dia tornar-se uma Estância Turística do Estado de São Paulo.

O PDDTMR é um documento público, e está disponibilizado no próprio site da Prefeitura. Ele foi elaborado por três graduandos em turismo e três bacharéis em turismo, sendo uma desses, a diretora da Divisão, no período em que foi elaborado.

A palavra lazer nesse documento aparece vinte e sete vezes, sendo que: três vezes foram nas diretrizes do documento, em que se pode observar a preocupação com o lazer na elaboração do documento, ou seja, uma tentativa de demonstrar que o lazer é uma das prioridades da Divisão de Esportes, Turismo e Cultura, mas a verdade é que o lazer foi utilizado nesses momentos apenas como nome de acompanhamento de outros segmentos, como o esporte, o turismo e a cultura.

Duas vezes a palavra aparece como referência bibliográfica. Apenas uma vez a palavra foi utilizada no intuito de demonstrar o quê um visitante procura quando elege um destino, o lazer e a hospitalidade foram os destaques dessa fala. Todas as outras vinte e uma vezes, a palavra referiu-se a espaços voltados para o lazer. Vale ressaltar que o PDDTMR possui um inventário turístico que relata todos os espaços públicos que são usados para o turismo, lazer, esportes e eventos. Portanto, na maioria dos espaços apresentados, o lazer foi indicado como possível uso do atrativo.

Sendo assim, verificamos por meio do site e do PDDTMR, que o lazer não é um dos objetivos centrais da Prefeitura Municipal, mas que ele está presente nesses documentos públicos. Mesmo que seja acompanhando outros setores, principalmente o esporte, essa presença diz muito sobre a intenção do munícipio em promover eventos públicos, onde a população consiga participar e conviver. Já que quando atrelada ao esporte, a palavra lazer se aproxima mais da comunidade local do que com turistas. Inerente a esse discurso 
documentado, reflete-se a qualidade de vida que o lazer, enquanto direito social, tende a promover na sociedade em que se insere.

Dessa forma, entendemos que o fato de as pessoas em formação, e formadas em turismo terem produzido tal documento conseguimos encontrar, ainda que pouca representatividade, certa preocupação com o bem-estar da comunidade local do município de Rosana e ainda, por meio do inventário turístico, informar e estimular o turismo na região.

Essa parceria com os acadêmicos do turismo poderia ir além do PDDMTR, e tentar se juntar a Presidente Epitácio para criar um roteiro turístico que abarcasse essas duas cidades, com outras da região, visto que Presidente Epitácio é uma Estância Turística e pode compartilhar de suas experiências com o município de Rosana e, em contrapartida, ganharia mais divulgação de sua cidade. 


\subsection{DISCUSSÃO DOS DADOS COLETADOS NA PESQUISA}

As cidades de Presidente Epitácio e Rosana, ainda que parecidas em suas paisagens e na utilização do mesmo recurso hídrico - Rio Paraná - considerado por todos os gestores como o principal atrativo turístico e espaço para lazer dos municípios por meio dos balneários, e compartilharem do mesmo contexto histórico regional, quando se trata do lazer se distanciam em larga escala entre si e do ideal que se acredita que poderia ser desenvolvido na área

Partindo para os objetos desse estudo, os Balneários Municipais de ambas as cidades, conseguimos com nossa observação estrutura, seguida por um roteiro pré-estabelecido, verificar-se os usos atuais destes espaços, número de pessoas que os frequentam, a conservação do meio e a presença do poder público enquanto gestão.

Utilizando essa técnica de coleta de dados (MARCONI; LAKATOS, 2010), foi possível identificar que os meses de verão, mais calor, (novembro, dezembro e janeiro) são os meses que os Balneários recebem mais visitantes e que mesmo nesses meses, os finais de semana são os que mais atraem as pessoas. Durante a primeira vista dezembro de 2016, o Balneário de Rosana recebeu nos finais de semana cerca de 140 pessoas, quanto que nos dias de semana foram aproximadamente 50 pessoas. Presidente Epitácio, manteve uma média similar, 120 pessoas aos finais de semana e 50 nos dias de semana.

Na segunda visita, fevereiro de 2017, os números já foram menores. Rosana tinha cerca de 100 pessoas nos finais de semana e 40 durante os dias de semana. Epitácio, 80 aos finais de semana e 30 nos dias de semana. Assim sendo, concluímos que a região sofre de sazonalidade e precisa se reinventar para atrair pessoas no restante do ano.

As atividades realizadas nos Balneários pelos frequentadores foram similares nas duas cidades. Banho, churrasco, piquenique, pesca, esportes de areia (vôlei e futebol), contemplação da paisagem e ski aquático. Atividades essas realizadas também no litoral do estado de São Paulo durante todo o ano, por brasileiros e estrangeiros.

Quanto à conservação dos ambientes também apresentaram resultados parecidos. Ausência de lixo pela areia e presença de cestos de lixo por todo o balneário; mata ciliar presente, apesar da reconstrução do Parque O Figueiral; animais nativos como aves da região, peixes e saguis; placas informativas sobre o comportamento permitido e não permitido nos espaços; som em volume aceitável. Nesse ponto se faz pertinente a discussão, já que é esse fator, a conservação, que vai manter esse espaço atrativo para as pessoas (moradores e 
visitantes). Portanto o poder público deve estar presente com ações que vão garantir o bem do ambiente natural em que o turismo e o lazer atuam.

Em relação à presença do poder público, observamos que ausência de acompanhamento, constante, das Prefeituras nos locais. Mas por outro lado, vemos a iniciativa com as placas informativas e proibitivas comportamentais; presença de salva-vidas em alta temporada; policiamento; conservação da infraestrutura recreacional como parques infantis, quadras esportivas; estacionamento gratuito em bom estado, e restaurante com credenciamento da Prefeitura. Além disso, esporadicamente, funcionários das Prefeituras comparecem nos Balneários para fazer a fiscalização e assim, garantir o cumprimento das regras estabelecidas, o que é preocupante, uma vez em que não se tem o controle do número de visitantes e nem do horário e permanência dos mesmos.

Os sites institucionais mostraram como a Prefeitura entende e prioriza o lazer. Em Rosana, ainda em número reduzido e com o intuito da referir-se apenas a atividade físicoesportiva, a palavra lazer é citada algumas vezes. Demonstrando que há uma preocupação com o lazer e bem estar da população. Em Epitácio, o caso foi diferente. Nenhuma menção a ao lazer em nenhuma das secretarias da Estância Turística de São Paulo, Presidente Epitácio.

Tratando de documentos municipais, Rosana, com a intenção de tornar-se um município de Interesse Turístico, desenvolveu o seu Plano Diretor de Desenvolvimento Turístico, contendo informações históricas, geográficas, econômicas, sociais, culturais e sobre os atrativos turísticos do município.

O lazer nesse documento é mencionado em sua maioria, como opção de atividade nos atrativos turísticos, mas também se refere às atividades esportivas e demonstra e uma aparição certa preocupação com o bem-estar da população local.

Presidente Epitácio ainda não possui um documento específico de turismo, por isso analisamos para esse estudo foi o Plano Diretor, que mesmo em menor quantidade, faz menção ao lazer que vai de encontro com as atividades esportivas. Ressalta-se aqui, que as estâncias turísticas de São Paulo estão passando por uma mudança de classificação, e que os planos do município, Plano Diretor e o Plano Diretor de Turismo, serão documentos obrigatórios para continuar a ser uma Estância ou para se candidatar a ser uma.

Outra técnica de coleta de dados foi utilizada para essa pesquisa, com o intuito de responder grande parte de nossos objetivos, foram as entrevistas semiestruturadas (TRIVIÑOS, 2008) para conhecermos os secretários/diretores de Turismo e Esportes de ambas as cidades. 
Ambos os secretários nos receberam com hospitalidade e foram solícitos com a entrevista. Destacamos aqui, que foram entrevistados, os diretores responsáveis pela pasta de turismo, esporte e cultura de Rosana, gestão 2013-2016 e gestão 2017-2020, e os secretários de turismo e cultura e secretários de esporte e educação, gestão 2013-2016 e gestão 20172020.

Quando questionados sobre quais políticas públicas destinadas ao lazer foram executadas em sua gestão, obtivemos respostas similares. Os diretores de Rosana pautaram-se nos eventos organizados pela Prefeitura em que a divisão de Esporte, Turismo e Eventos é responsável por coordenar. Eventos dos mais variados foram citados: feiras gastronômicas; eventos esportivos, culturais (teatros, cinema, e artesanatos), e religiosos (quermesses e festas juninas). $\mathrm{O}$ gestor mais antigo relatou que alguns projetos não conseguiram sair do papel, pois o dinheiro repassado para sua diretoria não era o suficiente para arcar com todas as despesas que os eventos demandavam, e, além disso, o número de pessoal (equipe) não era o suficiente para dar suporte para os eventos. Perguntamos se esses eram os únicos empecilhos enfrentados por ele e a resposta foi não, "há coisas que só a política enfrenta".

O gestor atual se justificou relatando que não teve tempo para colocar em prática todas as suas ideias, e que apenas tinha executado o evento do começo de ano (tradicional na cidade). Questionado sobre o número de funcionários de sua equipe e sobre a verba que sua diretoria arrecada para todos os eventos que pretende realizar o diretor foi pontual afirmando que com bom planejamento e administração ele e sua equipe conseguirão realizar todos os eventos que a cidade precisa.

Os secretários de Presidente Epitácio também responderam sobre seus eventos. O da gestão antiga de turismo e cultura pautou os eventos gastronômicos, culturais e de pesca. Já o secretário de Esporte e Educação relatou sobre os eventos esportivos e educacionais que ocorreram na cidade como campeonatos e recitais das escolas. Ambos relataram o número pequeno de suas equipes e a dificuldade financeira para executar mais eventos. Perguntamos se algum evento não acorreu e o motivo e eles responderam que todos ocorreram, mas que se tivessem mais ajuda financeira e de pessoal teriam realizado um evento melhor. Os novos secretários, disseram que não tiveram tempo para executar nenhum evento, mas estavam organizando o carnaval.

Nota-se pelas respostas dos secretários que o que eles compreendem por políticas de lazer são os eventos, e que a população e os turistas são limitados a essas ações pontuais, que são os eventos esporádicos organizados pela Prefeitura. Apesar das dificuldades de pessoal e de financeiro, os gestores afirmaram acreditar terem feito um bom trabalho no município e 
que serão lembrados pela população. Em contrapartida, os novos gestores estavam confiantes de que fariam um bom trabalho durante sua gestão e que conseguiriam atender a toda demanda da população.

Apesar de apenas citarem os eventos municipais como as políticas de lazer, ambos os gestores consideraram importante a elaboração de políticas de lazer para os municípios, porém não possuem documentos impressos ou digitais que podem comprovar essa fala.

Partindo dessas respostas, questionamos sobre o público que frequentava esses eventos, se eram moradores da cidade ou visitantes; número de pessoas e faixa etária. Sobre a faixa etária todos responderam de forma parecida, dependendo do evento, uma faixa etária era priorizada, mas nenhuma era descartada.

Quanto ao número de visitantes, nenhum dos gestores tinha esse controle. Já em relação à cidade de origem dos frequentadores, apenas o antigo gestor de esporte e educação de Presidente Epitácio conseguiu responder. Ele afirmou que os eventos de grande porte não são controlados, nem por quantidade nem por origem, mas que os eventos menores que envolviam as escolas eram frequentados por crianças e adolescentes da cidade. Já os esportivos, recebiam pessoas das cidades vizinhas também.

Processo similar ocorre em Rosana com os eventos esportivos. Pois, segundo o gestor (2013-2016) a cidade sedia campeonatos de futebol e handebol que recebe pessoas de todas as cidades da região.

Perguntamos como essas politicas de lazer são construídas e surgiram respostas diversas. O gestor antigo de Rosana relatou seguir um cronograma pré-estabelecido na Divisão, e que só altera esse cronograma se for para acrescentar por exigência de seus superiores, ou se não conseguiu executar pelas dificuldades relatadas (políticas de gabinete). O novo gestor disse que pretende seguir o mesmo cronograma, mas que quer incluir outros eventos durante o ano, principalmente que seja destinado para a terceira idade. Rosana é uma cidade que envelheceu. Os jovens saem cedo da cidade para estudar fora, e acabam, em geral, não voltando. Por esse motivo o discurso do gestor em enfatizar esse público.

Em Epitácio, o antigo gestor de turismo e cultura afirmou também ter um cronograma, mas que tentou durante sua gestão, variar os eventos para descobrir do que a população mais gostava. Questionamos se ele pretendia passar essas descobertas para o próximo gestor e ele respondeu afirmativamente, que gostaria de ver a cidade cada vez melhor. O novo gestor, afirmou que ainda não tinha recebido tais informações, mas que conhecia bem a cidade em que morava e que faria mais eventos para os adolescentes e 
adultos, e que gostaria de incluir eventos culturais que ressaltassem a história e o artesanato da cidade.

O antigo gestor de Esporte e Educação relatou ter incluído muitos eventos durante sua gestão, principalmente esportivos e que Epitácio estava com times representando a cidade em outros municípios. O atual gestor disse que pretende continuar com os campeonatos iniciados na gestão anterior e que se possível irá acrescentar mais eventos para as crianças, esportivos e educacionais.

Observamos por essas falas, que as preocupações pra quem destinar os eventos são diversas. E que por esse resultado, talvez, essas secretarias/divisões não estejam conversando entre si como deveriam. Estão individualizando seus problemas e não estão obtendo o efeito que gostariam com suas ideias, já que quando se juntassem os departamentos, conseguiriam um número maior de pessoas para auxílio da organização/execução e mais dinheiro. Seria essa uma solução para os problemas relatados por eles?

A articulação entre as políticas, perpassada pela intersetorialidade passa a ganhar dimensão para essa pesquisa, já que as políticas setoriais por si só não solucionam tudo e necessitam se comunicar para identificar as necessidades da população e os benefícios que pode ou não oferecer. Neste sentido, a intersetorialidade na gestão pública significa adotar uma decisão racional no processo de gestão, cuja aplicação pode ser positiva ou não. Ela não pode ser considerada antagônica ou substitutiva da setorialidade, mas complementar, ou seja, deve-se realizar uma combinação entre política setorial com intersetorial, e não contrapô-las no processo de gestão (Sposati, 2006). Conforme aponta Koga (2003, p. 242):

[...] a intersetorialidade se torna, assim, uma qualidade necessária ao processo de intervenção. Programas, projetos, equipes técnicas são desafiados ao diálogo, ao trabalho conjunto com a perspectiva da inclusão social. Neste caso, há de se fazer presente a participação dos membros da comunidade envolvida, enquanto sujeitos do processo da continuidade da proposta.

Ainda sobre os eventos organizados pelos gestores entrevistados, perguntamos o quão importante era esse serviço para população local e se eles acreditavam que esses eventos atraiam visitantes de cidades vizinhas.

O gestor antigo de Turismo destacou a importância do ambiente social e comum, afirmando que o bem-estar da comunidade gera qualidade de vida para todos e que, assim mais pessoas teriam vontade de conhecer Rosana. O novo gestor disse que acredita sim que os eventos atraiam mais pessoas para o município e que o mais importante desses momentos era estar junto com outras pessoas e compartilhar as experiências. 
O gestor antigo de Turismo e Cultura de Presidente Epitácio, afirmou que acredita na elevação no número de visitantes e que os eventos são importantes porque é o momento de lazer que a Prefeitura pode oferecer para os munícipes e visitantes. O gestor novo, afirmou o mesmo.

O gestor antigo e o novo de esportes e educação de Presidente Epitácio, concordam com o aumento de visitações durante os eventos, mas o primeiro ressaltou a importância da cultura por trás desses eventos, enquanto que o segundo ressaltou o bem-estar.

Todos os gestores foram unânimes em afirmar que os eventos são uma forma de arrecadar dinheiro para investir na cidade. Essa resposta veio antes de todas as outras. Primeiro mencionaram o fator econômico e depois o bem-estar, cultura, e qualidade de vida. Um discurso treinado dentro da política brasileira, especialmente no âmbito municipal.

Com relação à divulgação do município, ambas as cidades se utilizam dos mesmos recursos de propaganda: site, faixas estendidas pelo perímetro da cidade, vinhetas em rádios, redes sociais e folders impressos. Rosana utiliza-se dos slogans "Aqui começa São Paulo" e "O mais belo município do Pontal”. Já Epitácio utiliza "A joia ribeirinha" e "O mais belo Pôr do sol”. Esses métodos também são utilizados para divulgar e promover os eventos da cidade, sendo considerado por eles as vinhetas de rádio e as redes sociais como as mais eficazes para atingir o público.

Por último, foi questionado aos gestores se dentro da Prefeitura existem parcerias entre secretarias/divisões. Nessa questão apenas os gestores antigos responderam, pois os novos ainda não haviam passado por tal experiência. $\mathrm{O}$ Gestor de Rosana afirmou ter parcerias com as Divisões de Meio Ambiente, Educação e Planejamento e Gestão.

O gestor de Turismo e Cultura, afirmou ter parcerias com a Secretaria de Esportes e Educação e Obras Habitação e Infraestrutura.

O gestor de Esportes e Educação confirmou sua parceira com a Secretaria de Turismo e Cultura e disse que também tem parceria com Obras Habitação e Infraestrutura.

Visto que Rosana possui quinze divisões e Presidente Epitácio, dez, o número de parcerias se torna inferior do desejável. O ideal seria mais parceiras, em que todos os departamentos colaborassem com ideias, organização e execução desses eventos, e também nas demais propostas das Prefeituras. Dessa forma, cada departamento poderia colaborar com seu conhecimento específico e atender seus objetivos individuais e coletivos.

A dificuldade de comunicação entre as divisões/secretarias vai além de logística ou relacionamentos pessoais, trata-se de uma questão de iniciativa, uma vez que ninguém se prontifica a mudar esse cenário. 
A fim de conhecer, também as opiniões dos visitantes e moradores que frequentam os balneários, fizemos entrevistas com as pessoas que estavam nos balneários nos dias da visita técnica, questionando a respeito das iniciativas municipais. Tais entrevistas foram préelaboradas de forma semiestruturada, e aplicada ao maior número de pessoas que estavam no local, respeitando sempre entrevistar uma pessoa de cada grupo familiar ou de amigos.

A primeira questão da entrevista referia-se sobre a origem do visitante, ou seja, se era morados local ou se era turista. Em geral, grande parte dos frequentadores, aproximadamente 70\% das pessoas era residente de Rosana ou de Presidente Epitácio - conforme gráfico 1.

Ocorreu de haver pessoas de Rosana em Presidente Epitácio, mas não o contrário. Os outros 30\%, provinham dos municípios vizinhos. De Rosana: Euclides da Cunha, Teodoro Sampaio, Presidente Prudente, Pirapózinho e Anaurilândia. Em Presidente Epitácio: Presidente Venceslau, Campinal e Presidente Prudente. Ressalta-se que os números finais representam a média das duas cidades, pois estes foram semelhantes na pesquisa.

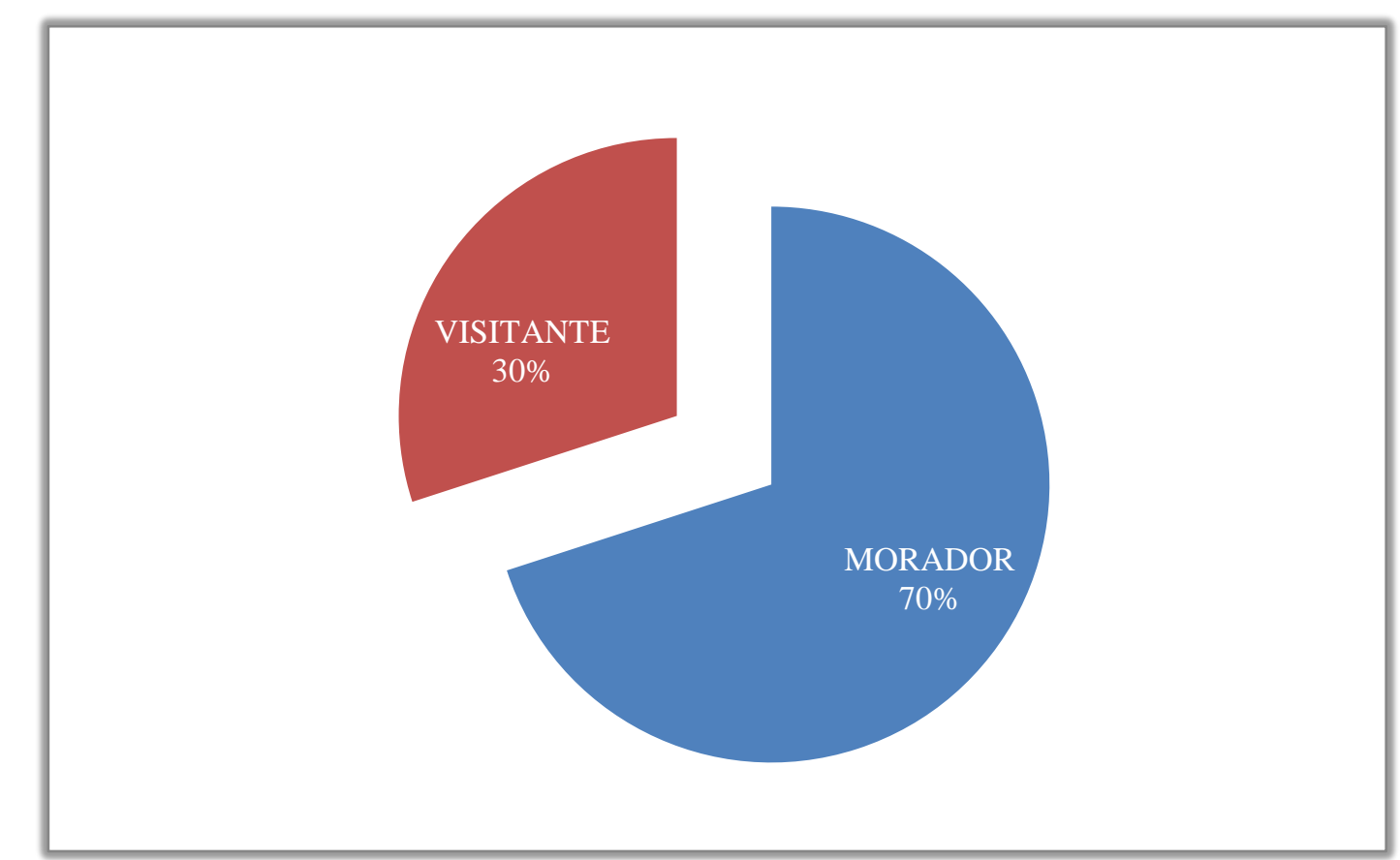

Gráfico 1 - Origem dos frequentadores dos Balneários Municipais de Rosana e Presidente Epitácio (Fonte: Roberta Dias de Moraes Ribeiro, 2017).

Foi questionado se os banhistas já tinham frequentado o balneário antes, se já conheciam ou se era a primeira vez naquele espaço. Entre os entrevistados $90 \%$ dos visitantes afirmaram já ter conhecido antes o balneário onde estava - Gráfico 2. Esse resultado desperta a atenção para alguns dados, como as pessoas gostarem de frequentar o balneário, 
reconhecerem esse espaço como um lugar de lazer e de descanso, e tornam a visitá-lo durante outros momentos no verão para realizar suas atividades de férias. Isso deveria ser de conhecimento das Prefeituras como forma de melhor atender esse público e, também, como forma de entender o porquê não estão atraindo novos públicos.

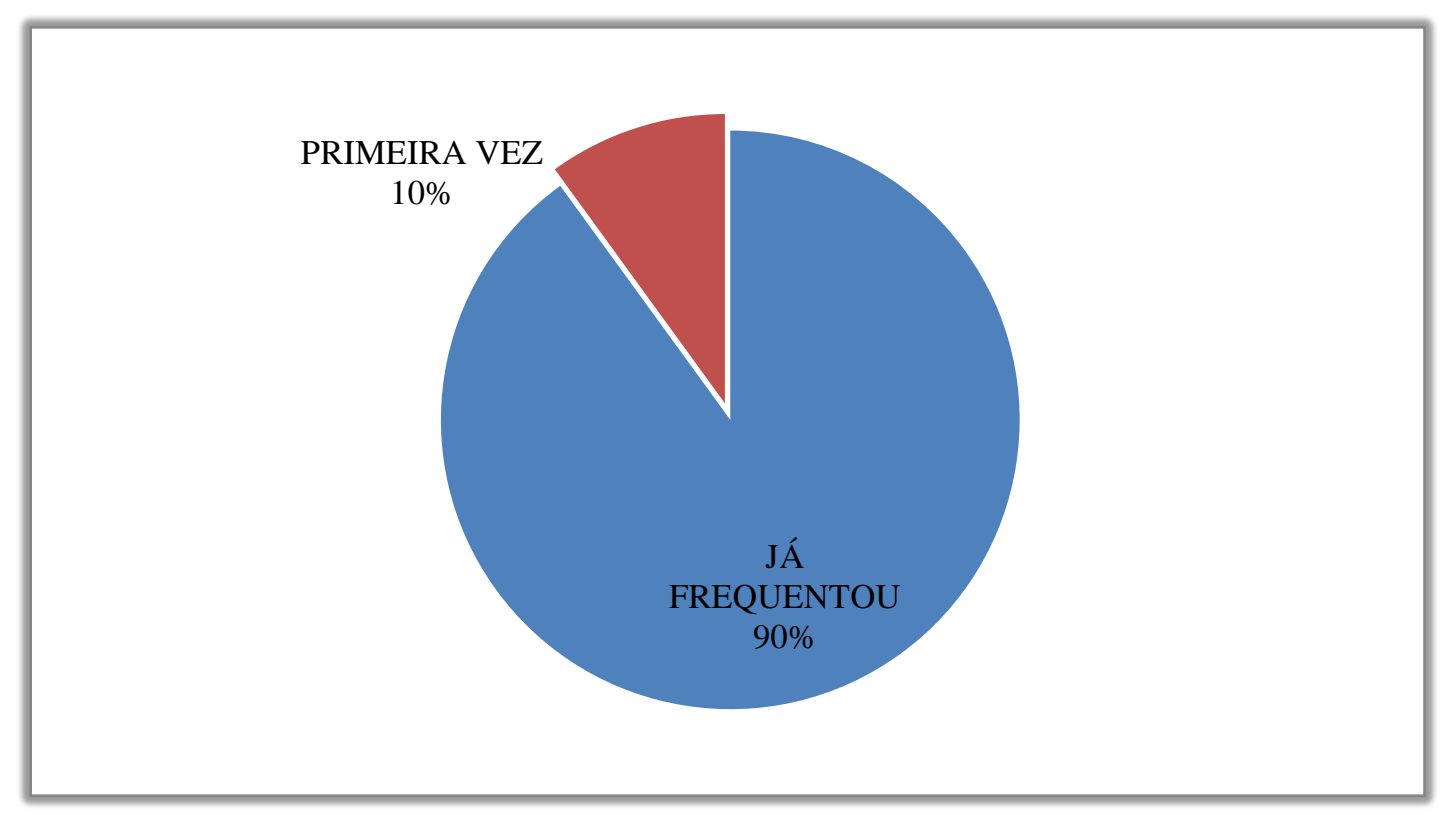

Gráfico 2 - Já conhecia o Balneário? (Fonte, Roberta Dias de Moraes Ribeiro, 2017).

Perguntou-se se o entrevistado se lembrava de alguma propaganda referente ao Balneário em que ele estava. As respostas foram similares em ambas às cidades. Grande parte das respostas foram relacionadas às propagandas em rádio e cartazes espalhados pela cidade com os dizeres "O mais belo município do Pontal" e "O mais belo pôr do sol". Diferente da fala dos gestores, as redes sociais não apareceram nessas entrevistas com relevância. Essa abordagem deve ser revistas pelos setores responsáveis para entender o motivo de suas divulgações não estarem chegando até o público frequentador dos balneários e dos possíveis frequentadores.

Sobre a participação dessas pessoas nos eventos municipais, a pesquisa aponta um resultado positivo, uma vez que todas as pessoas que afirmaram já conhecer o Balneário disseram frequentar os eventos organizados pela Prefeitura e ficam sabendo desses eventos por meio das vinhetas de rádio, por carros de som que circulam pela cidade e por folders fixados nos comércios. Importante destacar tais estratégias que atingem, em sua maioria, a população local, já que a rádio utilizada para divulgação dos eventos, segundo um dos 
entrevistados, não tem grande alcance na região, pois nas cidades vizinhas o sinal que chega não é de qualidade.

Uma das perguntas realizadas foi referente à satisfação dos frequentadores com relação à presença da Prefeitura nos balneários e as respostas de se distinguiram entre as duas cidades.

Em Rosana encontrou-se aprovação de $79 \%$ dos frequentadores, de acordo com o Gráfico 3. As respostas positivas relacionadas à Prefeitura ressaltaram a boa conservação do espaço, a presença de bombeiros em alta temporada, as lanchonetes padronizadas, a água limpa para banho, as placas de sinalização e os eventos promovidos pela Prefeitura. Em contrapartida, os negativos destacaram o volume alto dos eventos ali organizados, a má conservação dos quiosques para churrasco, área de camping sem delimitação, e a falta de fiscalização, referindo ao fato de há regras para utilizar o espaço público, mas que são cometidas pelo bom senso e não por fiscalização assídua da Prefeitura Municipal ou presença de policiamento constante.

Esse resultado demonstra, essencialmente, que por parte dos visitantes do balneário, a presença física da autoridade, seja por policiamento ou por representantes do poder público, é indispensável a fim de garantir o bom comportamento dos frequentadores, mesmo este sendo um espaço público.

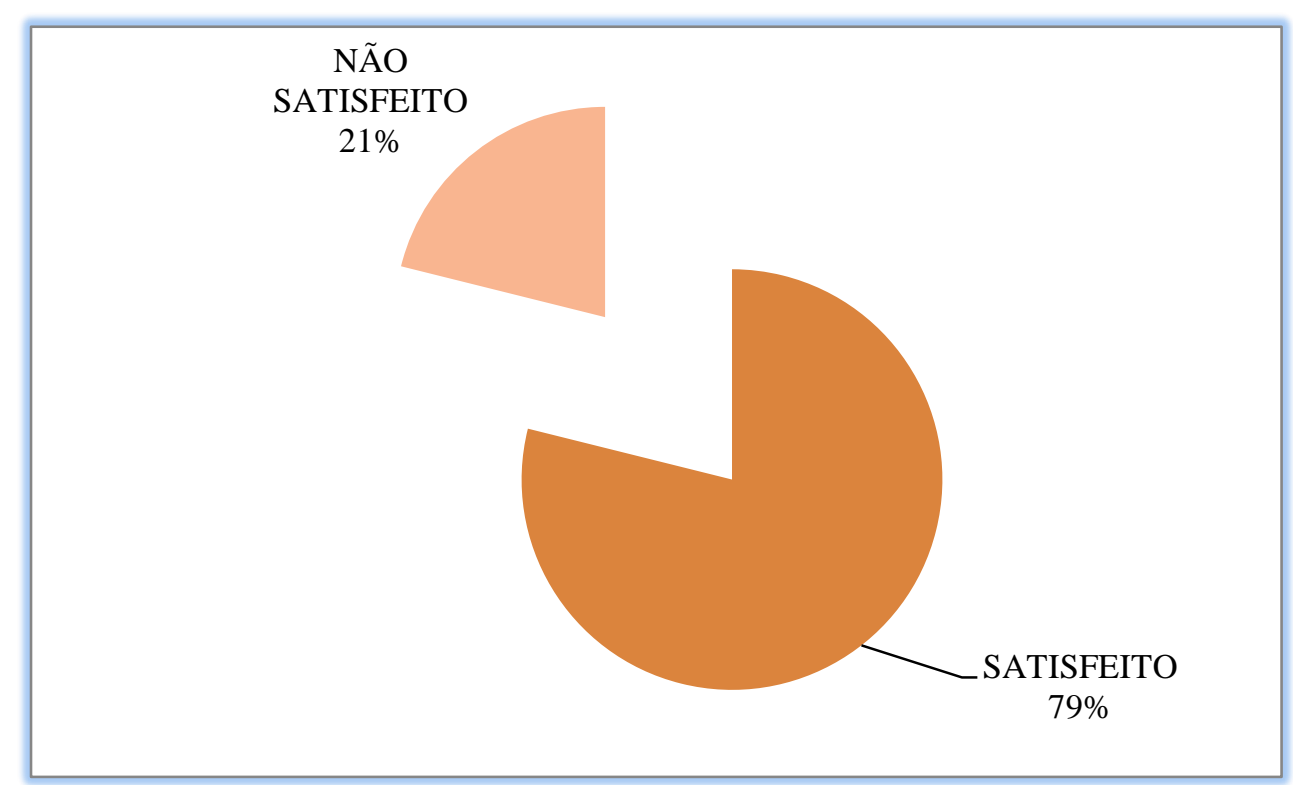

Gráfico 3 - Satisfação dos frequentadores do Balneário de Rosana com relação à Prefeitura Municipal (Fonte, Roberta Dias de Moraes Ribeiro, 2017). 
Em Presidente Epitácio, por outro lado, os resultados não foram animadores para o poder público. Apenas 54\% dos frequentadores disseram estar satisfeitos com a presença da Prefeitura Municipal no Parque Figueiral, e os outro 46\% negaram estar satisfeitos - Gráfico 4.

Entre as respostas positivas estavam, a ausência de lixos pelo balneário, placas informativas, bombeiros no local, controle de acesso - existe uma portaria que controla a entrada de veículos. Já entre as respostas negativas foram listadas, a conservação da infraestrutura como as lanchonetes, o coreto, as quadras esportivas, e o píer. Mesmo nas respostas satisfatórias, algumas pessoas relataram a ausência da Prefeitura no local. Faltam funcionários para fiscalizar o espaço e dar suporte aos visitantes. Um dos entrevistados citou o fato de Presidente Epitácio ser uma Estância Turística e não receber, por parte do poder público municipal, a atenção devida, já que o município recebe verba do DADETUR Departamento de apoio às estâncias - destinada aos atrativos turísticos da cidade.

De forma similar a Rosana, o que foi compreendido com essa pergunta é que o trabalho realizado pela Prefeitura no Balneário, não é o suficiente para seus frequentadores, uma vez que esse serviço não é visualizado (visível), dando a entender que os investimentos que a Secretaria de Turismo e Cultura recebe para aplicar no Parque O Figueiral não são destinados a esse fim.

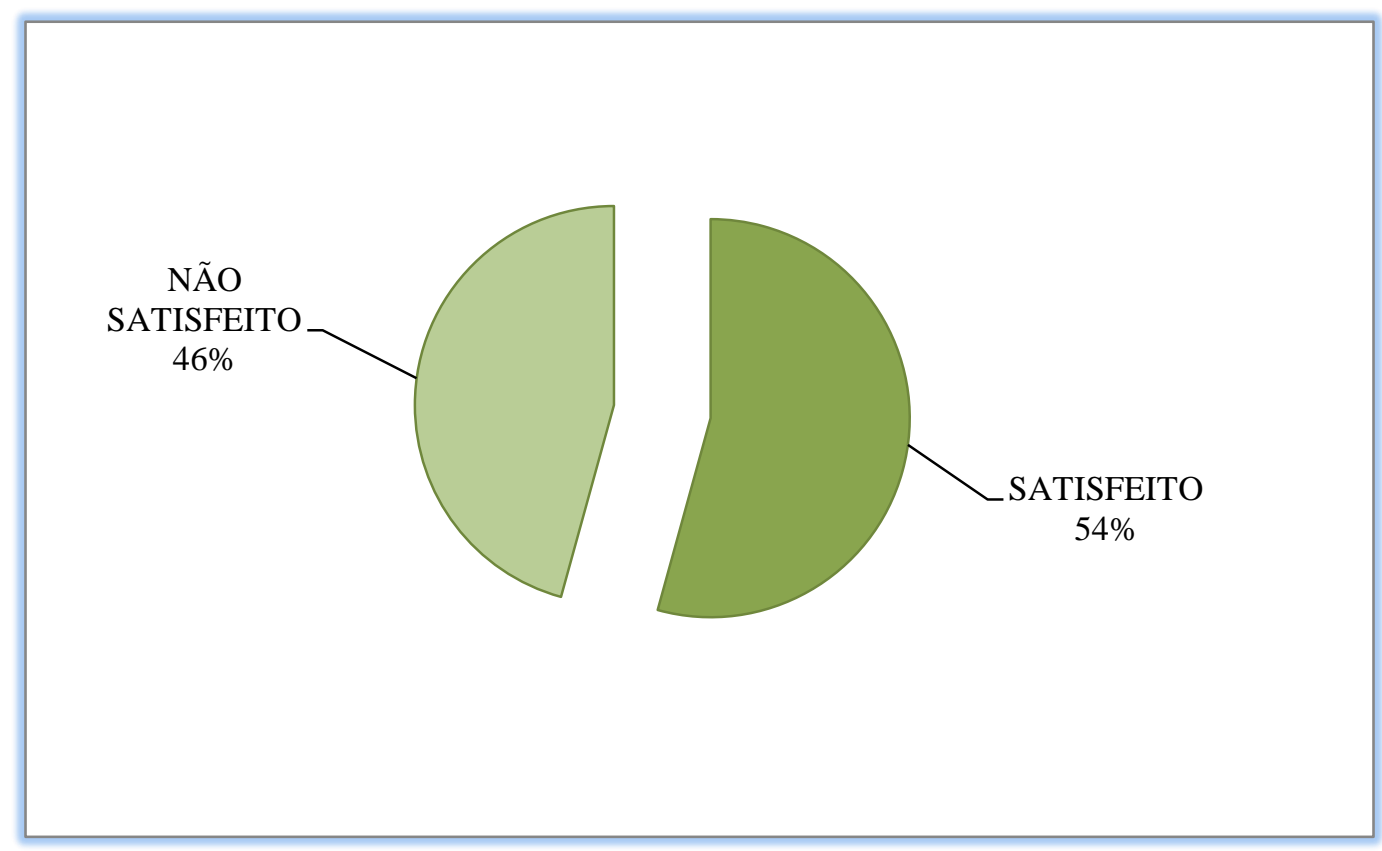

Gráfico 4 - Satisfação dos frequentadores do Balneário de Rosana com relação à Prefeitura Municipal (Fonte, Roberta Dias de Moraes Ribeiro, 2017). 
Como última questão, foi perguntado sobre o contentamento dos frequentadores quanto aos eventos realizados nos balneários, já que esse foi o foco dos gestores entrevistados em relação ao lazer do município.

Em geral os entrevistados responderam que estavam contentes com os eventos, representando um total de $82 \%$, contra $18 \%$ não contente (Gráfico 5). Quase que em unanimidade as respostas positivas e negativas demonstraram que gostariam de mais eventos, principalmente, esportivos e shows artísticos nos balneários como opções de entretenimento.

Esses últimos comentários apareceram como forma de recomendação, onde as pessoas disseram que moravam em uma cidade pequena e com poucas opções de lazer e entretenimento e que esperavam que essa iniciativa viesse do poder público municipal.

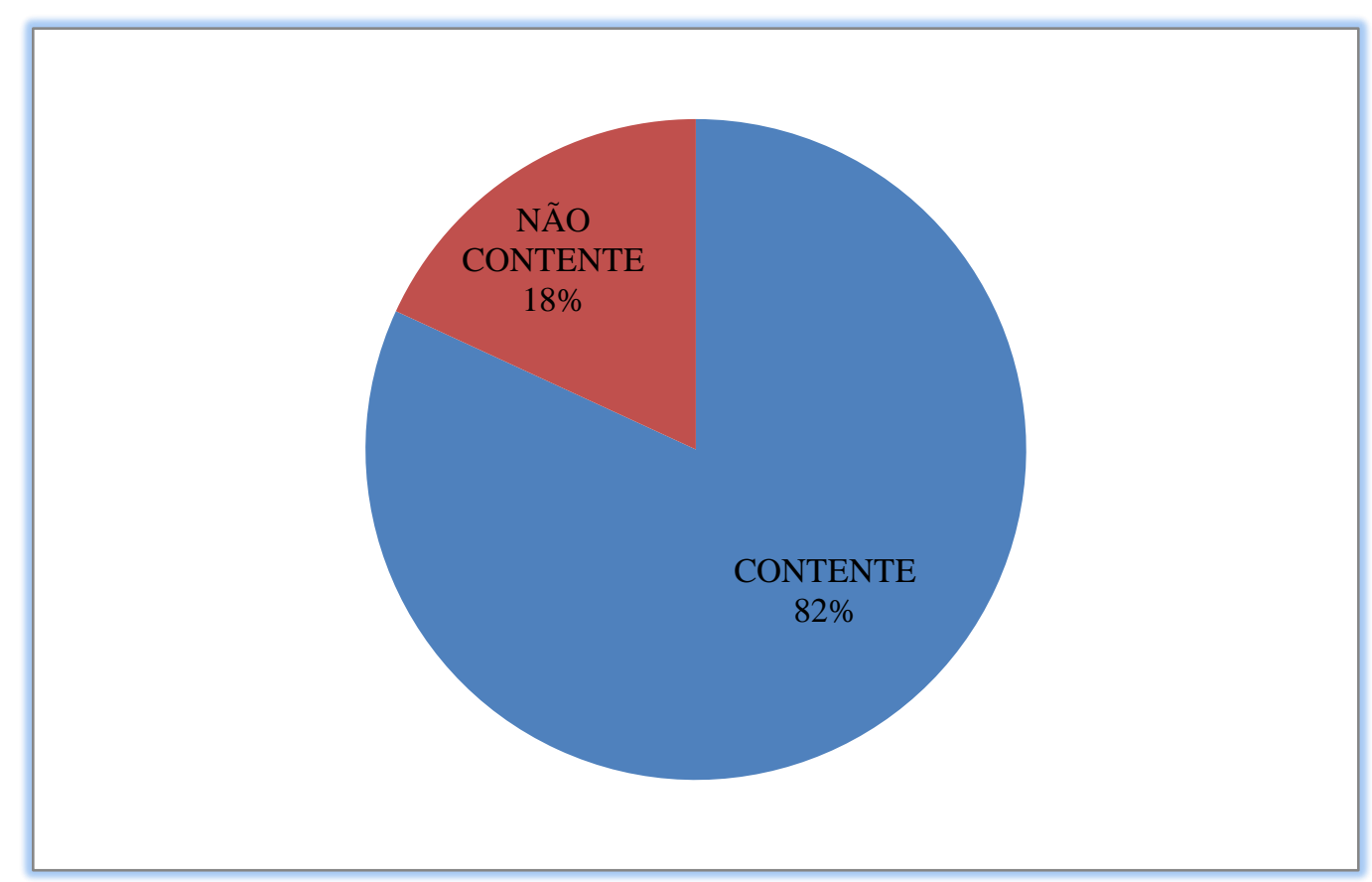

Gráfico 5 - Está contente com os eventos que ocorrem no balneário? (Fonte, Roberta Dias de Moraes Ribeiro, 2017).

A aplicação da observação estruturada e seus itens analisados apontam dados que vão de encontro com as entrevistas direcionadas aos frequentadores dos balneários. Ambos relataram sobre a conservação dos espaços, a ausência física do poder público e a infraestrutura do local.

Já em relação às entrevistas com os gestores quando comparadas as entrevistas dos frequentadores divergem em alguns aspectos, como o número de eventos realizados e a divulgação dos mesmos. Porém, ambas conversam quanto ao segmento do lazer que o público 
mais gostaria de ter na cidade e com o que os gestores, em sua maioria, consideram como prioritários, os eventos esportivos.

Por fim, entende-se que os gestores públicos reconhecem que os balneários municipais são os seus principais atrativos turísticos e também seu principal espaço de lazer. Entretanto, as prioridades das prefeituras municipais ainda não permitem que seja feito mais por esses locais.

O fato de a população não expressar suas demandas e reivindicar por mais lazer em seus municípios, não participando, efetivamente, nas tomadas de decisões, acaba criando um distanciamento entre o poder público municipal e a população e, dessa forma, sem diálogo, o poder público fica em atender as necessidades da comunidade local e, por consequência, dos turistas.

Cabe destacar que os balneários foram criados, inicialmente, como estratégia de turismo e de lazer. Mesmo que com viés e apelo econômico nos discursos dos políticos, ainda sim, o intuito era de propagação de atividades sociais. É importante que esse objetivo não seja perdido e que a política saiba administrar, por meio de suas secretarias/divisões, esses espaços e consigam promover o lazer para seus visitantes. Afinal, um direito social, garantido na Constituição, deve ser oferecido a todos como forma de promover qualidade de vida e bemestar social. 


\section{CONSIDERAÇÕES FINAIS}

Reafirmando o que já foi mencionado anteriormente, as discussões trazidas para essa pesquisa tinham como finalidade compreender o lazer em espaços públicos e naturais como é o caso dos balneários municipais. Nesse sentido, ao analisar os balneários tentamos abarcá-los como alternativas de lazer para o oeste paulista, sob a perspectiva de que estes se comparam com o litoral brasileiro.

Claro que essa comparação não enquadra a água (salgada do mar e doce do rio), nem em extensão (quase oito mil quilômetros de costa litorânea), nem de paisagem (já que os balneários municipais são ambientes modificados pelo homem, a exemplo da areia que é inserida no local). Contudo, a paisagem natural, vegetação e horizonte são semelhantes às praias do litoral, e sobretudo, as atividades que são realizadas nos balneários e, por consequência, a motivação que que leva os visitantes a esses ambientes.

A criação dos balneários municipais foi uma estratégia das Prefeituras em promover seus municípios por meio do turismo. Transformar os reservatórios das hidrelétricas e atrair os turistas para sua cidade representava arrecadar mais dinheiro, movimentar a economia local, desenvolver a cidade e se destacar regionalmente. Ou seja, esses espaços foram construídos com o intuito de salvar os municípios, um projeto que exigia planejamento e acompanhamento técnico.

Em geral, o turismo tem esse título de salvador de todos os problemas, enaltecendo os aspectos econômicos. Mas a verdade é que quando não planejado e administrado o Turismo pode não atender as demandas de uma cidade e ainda causar impactos negativos.

Quando se trata de lazer no poder público o cenário é diferente por diversos motivos. O primeiro, e quiçá o mais importante, é que a gestão pública diverge sobre o entendimento do lazer e sua importância na vida cotidiana das pessoas. Não existem entendimento claro de seus conceitos que permitam desenvolver políticas especificas para tal, uma vez que os gestores não conhecem o conteúdo, seus valores, benefícios e como proporcioná-lo a sua comunidade local.

A experiência de se ter um balneário, que a princípio seria um atrativo turístico, em sua cidade não modifica essa realidade. A exemplo dos gestores entrevistados para essa dissertação, vê-se que a visão deturbada sobre a definição do lazer não permite com que estes desenvolvam projetos com esse objetivo.

Infelizmente, esse não é um panorama destinado exclusivamente aos gestores públicos. Apesar de o lazer configurar como um direito social previsto em Lei, a população, de forma generalizada, não o figura como prioridade em seu cotidiano. Muitas vezes 
influenciada pela mídia, o lazer é o primeiro item a ser excluído, ou deixado de lado por um tempo, pelas pessoas. Isso porque se trata de algo supostamente supérfluo e que, quando comparado à saúde, por exemplo, poderia esperar, assim como quando relacionado a outras áreas mais "importantes" na vida social.

Por outro lado, a prática do lazer pode interferir diretamente, na saúde mental das pessoas e por processos diferentes provocar a formação de valores questionadores da vida social. Quem tem acesso ao lazer, pode vivenciar um caminho que colabore com a vivência de situações mais participativas, que colaborem para além do escape do estresse do cotidiano do trabalho, dos grandes centros, poluição, problemas familiares, entre outros. $\mathrm{O}$ escape da rotina reflete-se totalmente nos dias que se procedem (RIBEIRO; GRANADO, 2015), como forma de ajudar as pessoas a conviverem com as injustiças cotidianas.

O relacionamento com outras pessoas, ou com as mesmas do cotidiano, mas de forma diferente, muda o olhar que se tem sobre elas. É importante destacar que o lazer não é mais importante do que a saúde, que o trabalho, que as demais necessidades, mas que este deveria ganhar mais espaço nas discussões e nas ações que poderiam ser desenvolvidas pelo poder público e deveria ser considerado como um dos itens entre as prioridades da população.

Diante do descaso com o lazer por parte da população e por parte dos gestores municipais, encontramos nas cidades de Rosana e Presidente Epitácio um reducionismo do termo. Os gestores entrevistados compreendem, no processo de planejamento das políticas públicas de lazer dos balneários, apenas o conteúdo físico esportivo (DUMAZEDIER, 1980a). Utilizam uma agenda de eventos, a maioria deles esportivos, em detrimento dos demais, realizados em menor número nas políticas pública de lazer dos municípios. Nem mesmo em seus documentos oficiais, Plano Diretor e Plano Diretor de Turismo, não figuram outros conteúdos que demonstram estarem presentes para o planejamento de outras iniciativas para o lazer. Assim, as secretarias/divisões de turismo e lazer não fornecem opções plausíveis de práticas de lazer para sua comunidade a não ser os eventos organizados nos balneários.

Em contrapartida, mesmo não figurando nos discursos dos gestores, quando os visitantes foram questionados sobre as práticas de lazer que exerciam nos balneários, algumas das respostas em comum foram: práticas esportivas nas quadras de vôlei e futebol; churrascos nos quiosques e banho com as crianças. E quando questionados sobre a conservação do local, os frequentadores disseram estar satisfeitos com a maioria da infraestrutura dos balneários. Essas respostas indicam, no entanto, que mesmo não reconhecendo como conteúdo do lazer, o social está presente em suas ações, visto que a conservação dos equipamentos de lazer é considerada nas ações das Prefeituras Municipais. 
Como já referido, a política pública de lazer considerada pelos gestores é a sua agenda de eventos. Nos documentos analisados não são feitas alusões sobre qualquer política de lazer, ou prioridade com a mesma. Nos sites institucionais também não há menções sobre políticas de lazer. Comprovando o descaso e a falta de conhecimento para com o lazer nos municípios estudados. Acreditamos, todavia, que essa não seja a realidade que se concretiza apenas nessas duas cidades paulistas.

Sobre os projetos de lazer que não foram realizados durante a gestão (2013-2016), as explicações dadas pelos gestores foram referentes ao número de funcionários que as secretarias/divisões possuíam e sobre o quanto de verba teria sido destinado para elas. Porém o que fica implícito nos discursos é a questão política. Ou seja, as dificuldades que foram relatadas seriam pontuais e ditas por todos os seis gestores, mas a questão política fica evidente quando em alguns momentos é exposta a falta de autonomia para elaborar projetos propostos para o lazer.

Já com relação aos projetos futuros, os gestores foram confiantes com o planejamento e realização de novos eventos (considerados a política de lazer dos balneários). Vale ressaltar, que as entrevistas ocorreram no início das gestões e, portanto, não haviam ocorridos eventos organizados por esses novos gestores. Ambos os gestores pretendiam considerar os eventos já tradicionais nos municípios e, também organizar novos projetos de eventos, com o intuito de atrair mais turistas e movimentar a economia local.

Aproveitando essa confiança dos gestores para com os eventos futuros nos balneários municipais, necessitamos entender para quem estes seriam planejados. Em geral, os gestores não conseguiram responder de imediato essa questão. Disseram que todas as faixas etárias são priorizadas, crianças, jovens, adultos, e idosos. Porém, quando comparado com a realidade dos eventos que ocorrem nos balneários notamos uma disparidade entre os dois, pois os eventos que já acorrem são, em sua maioria, de esportes para adolescentes e adultos, e shows para adultos.

Com a finalidade de saber como os próximos eventos, os que seriam planejados pela primeira vez, seriam desenhados, fez-se essa pergunta aos novos gestores. Diante da resposta anterior (de que todas as faixas etárias são contempladas pelas políticas públicas), conclui-se que assim continuaria sendo, todos teriam seu momento de lazer nos balneários.

Perante essa afirmação, deseja-se que ela não se torne apenas um discurso e entre em vigor para a próxima gestão. Esse também é o desejo dos frequentadores dos balneários, que expressaram seu sentimento de ter mais eventos para contemplar e participar. Se essa 
estratégia for adotada, a prioridade dos gestores o aumento na movimentação da economia e, por consequência, no número de turistas.

Como se trata de ambientes naturais, ainda que reconstruídos pelo homem, existe uma preocupação com a natureza dos locais. A água que banha os balneários necessita de acompanhamento e monitoramento, para que assim, sua qualidade seja respeitada e não cause problemas para a população, especialmente por se tratar de rio com excelente avaliação de água (RIBEIRO; GRANADO, 2015).

A vegetação é outro ponto a ser motivo de atenção da gestão pública municipal, pois com o aumento da visitação nesses espaços é possível que haja degradação do ambiente natural, um dos impactos negativos do turismo (ALMEIDA, 2003). Então, se o objetivo das prefeituras é aumentar o fluxo de pessoas nos balneários é obrigação destas serem zelosas quanto o ambiente natural, para que assim não destrua esses locais e a população não tenha que herdar os efeitos negativos da atividade turística.

Essa é uma preocupação que se estende aos estabelecimentos alimentícios instalados nos balneários municipais, pois se trata de comércios que necessitam de saneamento básico, energia elétrica e geram lixos. O lixo também é outro item a ser pensado. O lixo produzido pelo homem não deve, de forma alguma, ser direcionado ao rio ou ser deixado às margens dele. A poluição do rio causaria a degradação desse recurso hídrico e impediria o contato do homem com a água, vide o monitoramento de qualidade.

Como não foram encontrados lixos deixados nos balneários, percebe-se que há preocupação com a paisagem do lugar. A presença de lixeiras por toda a extensão representa esse cuidado. Entretanto, deve-se atentar para o destino fim destes lixos. A reciclagem é uma das opções válidas para solucionar essa questão, já que muitos desses resíduos são embalagens plásticas e de papel levadas pelos turistas.

Versando sobre esse tema, compreendemos a necessidade de interação entre as secretarias/divisões. Se houver esse diálogo, uma transversalidade, entre os departamentos públicos, muitos dos problemas já enfrentados e as consequências dos que são ignorados, podem ser resolvidos.

Exemplo disso pode-se indicar os departamentos de meio ambiente, educação, obras e infraestrutura, finanças, saúde, social, entre outras. Que versariam sobre as questões de conservação ambiental (vegetação e fauna), resíduos sólidos, monitoramentos das águas, inclusão e direcionamento de atividades para todas as idades, infraestrutura das lanchonetes e de todos os equipamentos dos balneários, eventos de sociabilidade, e movimentação da economia. Todo esse conjunto de departamentos poderia e deveria junto, prover o lazer nos 
seus municípios, visando melhoria de qualidade de vida. Os benefícios da intersetorialidade aqui mencionada devem ser entendidos para além das simples ações conjuntas nas realizações dos eventos, mas sim como forma de estabelecer diretrizes e objetivos com os setores, em um viés de participação/deliberação. Além disso, a intersetorialidade deve planejar, executar e organizar a prestação de serviços, com o intuito de garantir acesso igual a todos.

Infelizmente, esse é um cenário ideal para os municípios da pesquisa e não a realidade. Os gestores afirmaram durante suas entrevistas que há diálogo com algumas secretarias/divisões e que, normalmente, aconteceria para a execução dos eventos programados na agenda, já que o número de funcionários em cada departamento não seria o suficiente para suprir os eventos.

Um ponto questionado aqui é referente à união desses municípios, no sentido de ajudarem a se promover e aprender, pois ambos utilizam o mesmo recurso hídrico, no mesmo modelo de atrativo, que é o balneário.

Conversas em formato de reuniões seriam uma grande oportunidade de troca de conhecimentos e experiências, principalmente pelo falo de Presidente Epitácio ser uma Estância Turística de São Paulo e Rosana ter interesse em ser uma Estância e ainda ser Município de Interesse Turístico (MIT). Tal parceria poderia identificar um público-alvo, a partir de suas divulgações, em busca, do desenvolvimento de um roteiro turístico para o Pontal do Paranapanema.

Outra parceria possível para o desenvolvimento turístico dessas cidades, por meio dos balneários seria com a Universidade Estadual Paulista - UNESP, que no município de Rosana, possui o curso de graduação em turismo. Como foi feito com o Plano Diretor de Desenvolvimento Turístico Municipal de Rosana, a UNESP seria uma aliada para conseguir fomentar o turismo nos municípios e na região.

Levando-se em consideração que os balneários são, indiscutivelmente, os principais atrativos turísticos de suas respectivas cidades, é impossível não questionar a ausência de projetos que visem o lazer da população e dos visitantes. Fez-se uma relação direta do Turismo com o Lazer, pois o espaço público de Turismo em questão é, também, o principal local de lazer para a comunidade local, visto que durante as entrevistas, os visitantes afirmaram ir aos balneários com frequência, especialmente, no verão.

Ambas as cidades, por sua localização, não sofrem com grande sazonalidade. $O$ Pontal do Paranapanema tem um clima tropical, úmido e, na maior parte do ano, os dias são quentes. Assim, aumentam os dias de visitação dos balneários. Por outro lado, as pessoas preferem visitá-los em épocas mais quentes e de férias. Daí o planejamento da gestão pública 
municipal em prover atividades durante o ano em momentos que sejam diferentes da época mais utilizada pela população, sem descuidar dessas datas concorridas. Esse é o papel que as secretarias/divisões entrevistadas deveriam exercer em conjunto com os demais departamentos.

Portanto, apesar de figurarem como potenciais de alternativas de lazer, os métodos de divulgação e propaganda que as secretarias/divisões pesquisadas utilizam para promover seus balneários, não têm sido suficientes para romper as fronteiras de seus municípios. Muito provavelmente, a visão deturbada e unificada do entendimento de lazer dos gestores públicos impede com esse problema seja sanado.

O poder público, de forma geral e aqui utilizada em âmbito municipal, tem o papel de representatividade de sua comunidade e os cargos aqui estudados (secretários e diretores), são cargos de confiança, mas que são determinados por pessoas eleitas pela comunidade. Sendo assim, cabe a esses políticos desenvolverem políticas que abarquem essa população local, visando à qualidade de vida de todos. É importante que a comunidade também participe das tomadas de decisão das Prefeituras, para que suas demandas sejam supridas.

Se o turismo é um dos objetivos principais desses municípios, a fim de desenvolver as cidades economicamente, porque não pensar em políticas públicas, em parceiras com os demais departamentos das Prefeituras, que abarquem o lazer e melhore, em diversos aspectos como apresentado, a vida dos moradores de Presidente Epitácio e Rosana? 


\section{REFERÊNCIAS}

ACERENZA, M. A. Administração do turismo: conceituação e organização. 4. ed. Bauru: Edusc, 2002.

AGÊNCIA NACIONAL DAS ÁGUAS - ANA. Caderno de Recursos Hídricos: o turismo e o lazer e sua interface com o setor de recursos hídricos. Brasília, 2005. Disponível em:<http://http://www.ana.gov.br/pnrh_novo\%20/documentos/06\%20Turismo/VF\%20Turis mo\%20Lazer.pdf.\%20A>. Acesso em: 29 de março. 2015.

ALMEIDA, M. G. Lugares turísticos e a falácia do intercâmbio cultural. In: ALMEIDA, M.G. Paradigmas do turismo. Goiânia: Alternativa, 2003, p. 11-22.

AOUN, S. A procura do paraíso no universo do turismo. Campinas: Papirus, 2001.

ARAÚJO, S. M. Artifício e Autenticidade: o turismo como experiência antropológica. In: BANDUCCI JÚNIOR, A., BARRETO, M. (Orgs.) Turismo e identidade local - uma visão antropológica. Campinas: Papirus, 2001, p. 49-63.

BARBOSA, F. S.; CAMPAGNA, J. Animação Sociocultural e o segmento do idoso: reflexões e sugestões. In: MARCELLINO, N. C. Lazer e Recreação: Repertório de Atividades por Fases da Vida. 2. ed. Campinas, SP: Papirus, 2006. 147-156 p.

BENI, M. C. Análise Estrutural do Turismo. 10. ed. São Paulo: Editora Senac São Paulo, 2006.

BIANCHI, A. C.M. Manual de orientação: estágio supervisionado. 4. ed. São Paulo: Cengage Learning, 2003.

BONI; QUARESMA. Aprendendo a entrevistar: como fazer entrevistas em Ciências Sociais. In: Revista Eletrônica dos Pós-Graduandos em Sociologia Política. UFSC. Vol. $2 \mathrm{n}^{\mathrm{o}} 1$ (3), janeiro-julho, 2005, p. 68-80. 
BOMFIM, L. C. E. O turismo como alternativa de desenvolvimento local no município de Presidente Epitácio: representações sociais e culturais de identidade local. 2006. $117 \mathrm{f}$. Trabalho de Conclusão de Curso (Dissertação) - Mestrado em Desenvolvimento Local. Universidade Católica Dom Bosco. Campo Grande/MS, 2006. Disponível em: $<$ http://site.ucdb.br/public/md-dissertacoes/7953-o-turismo-como-alternativa-de-

desenvolvimento-local-no-municipio-de-presidente-epitacio-representacoes-sociais-eculturais-de-identidade-local.pdf> Acesso em: 14 de ago. 2016.

BRANCO, S. M. \& ROCHA, A. A. Poluição, Proteção e usos Múltiplos de represas. São Paulo: Edgard Blücher/CETESB, 1977.

BRANCO, S. M; AZEVEDO, S. M. F. O.; TUNDISI, J. G. Água e saúde humana. In: TUNDISI J. G; BRAGA B; A. C. REBOUÇAS (Orgs). Águas doces do Brasil: Capital ecológico, uso e conservação. 3. ed. São Paulo: Escrituras Editora, 2006.

BRASIL. Lei No 6.505, DE 13 DE DEZEMBRO DE 1977. Dispõe sobre as atividades e serviços turísticos; estabelece condições para o seu funcionamento e fiscalização; altera a redação do artigo 18, do Decreto-Lei $\mathrm{n}^{\circ}$ 1.439, de 30 de dezembro de 1975; e dá outras providências. Disponível em: < http://www2.camara.leg.br/legin/fed/lei/1970-1979/lei-650513-dezembro-1977-366476-norma-pl.html>. Acesso em: 24 abr. 2017.

$\begin{array}{lllllllll}\text { BRASIL. Lei } & \mathbf{N}^{\circ} & \mathbf{1 1 . 4 3 8} & \text { DE } & 29 & \text { DE } & \text { DEZEMBRO } & \text { DE } & 2006 .\end{array}$ Dispõe sobre incentivos e benefícios para fomentar as atividades de caráter desportivo e dá outras providências. Disponível em: < http://www.planalto.gov.br/ccivil_03/_ato20042006/2006/lei/111438.htm>. Acesso em: 24 set. 2017.

BRASIL. PLANO AQUARELA: Marketing turístico internacional do Brasil 2007 - 2010. Disponível em: http://www.embratur.gov.br/lai_embratur_secom/export/sites/lai/galerias/download/Plano_Aq uarela_2007_a_2010.pdf> Acesso em: 1 de ago. 2016.

BRASIL. DECRETO-LEI No 2.294, DE 21 DE NOVEMBRO DE 1986. Dispõe sobre o exercício e a exploração de atividades e serviços turísticos e dá outras providências. 
Disponível em: http://www.planalto.gov.br/ccivil_03/decreto-lei/1965-1988/Del2294.htm>. Acesso em: 10 nov. 2015.

BRASIL. LEI No 6.645 DE JANEIRO DE 1990. Dispõe sobre alterações no Quadro Territorial Administrativo do Estado. Disponível em: < https://governosp.jusbrasil.com.br/legislacao/185311/lei-6645-90> Acesso em 29 de fev, 2017.

BRASIL. LEI No 6.956 DE 20 DE SETEMBRO DE 1990. Transforma em Estância Turística o Município de Presidente Epitácio. Disponível em: < https://governosp.jusbrasil.com.br/legislacao/184317/lei-6956-90> Acesso em: 20 dez. 2016.

BRASIL. Lei No 8.181, DE 28 DE MARÇO DE 1991. Dá nova denominação à Empresa Brasileira de Turismo - EMBRATUR, e dá outras providências. Disponível em: < http://www2.camara.leg.br/legin/fed/lei/1991/lei-8181-28-marco-1991-363895-normapl.html>. Acesso em: 27 abr. 2017.

BRASIL. DECRETO No 448, DE 14 DE FEVEREIRO DE 1992. Regulamenta dispositivos da Lei ${ }^{\circ}$ 8.181, de 28 de março de 1991, dispõe sobre a Política Nacional de Turismo e dá outras providências. Disponível em: <http://www.planalto.gov.br/ccivil_03/decreto/19901994/D0448.htm>. Acesso em: 11 jan. 2015.

BRASIL. Diretrizes para uma Política Nacional de Ecoturismo. Sílvio Magalhães Barros, Denise Hamú M. De La Penha (coord.). Brasília: EMBRATUR, 1994.

BRASIL. DECRETO-LEI No 55, DE 18 DE NOVEMBRO DE 1996. Define a política nacional de turismo, cria o Conselho Nacional de Turismo e a Empresa Brasileira de Turismo, e dá outras providências. Disponível em: <http://www.jusbrasil.com.br/legislacao/109350/decreto-lei-55-66>. Acesso em: 03 abri. 2016.

BRASIL. LEI COMPLEMENTAR N 50/2006 DE 10 DE OUTUBRO DE 2006. Promove a revisão do Plano Diretor da Estância Turística de Presidente Epitácio. Disponível em: <http://www.presidenteepitacio.sp.gov.br/leis/plano-diretor/lei-complementar-n-50-2006revisao-plano-diretor.pdf > Acesso em: 15 dez. 2016. 
BRASIL. LEI No 11.771, DE 17 DE SETEMBRO DE 2008. Dispõe sobre a Política Nacional de Turismo, define as atribuições do Governo Federal no planejamento, desenvolvimento e estímulo ao setor turístico; revoga a Lei $\mathrm{n}^{\circ} 6.505$, de 13 de dezembro de 1977, o Decreto-Lei $n^{\circ} 2.294$, de 21 de novembro de 1986, e dispositivos da Lei $n^{\circ} 8.181$, de 28 de março de 1991; e dá outras providências. Disponível em: < http://www.planalto.gov.br/ccivil_03/_ato2007-2010/2008/lei/111771.htm>. Acesso em: 25 abr. 2017.

BRASIL, Ministério do Turismo. Planos Nacionais, 2014. Disponível em:http://www.turismo.gov.br/turismo/o_ministerio/publicações/cadernos_publicações/03pla nos_nacionais.html. Acesso em: 19 out. 2016.

BRASIL. Hábito de consumo do turismo brasileiro. Ministério do Turismo. Disponível em: < http://www.turismo.gov.br/publicacoes/item/31-habitos-de-consumo-do-turismobrasileiro.html>. Acesso em: 22 nov. 2016.

BRENNER, A. K.; DAYRELL, J.; CARRANO, P. Cultura do lazer e do tempo livre dos jovens brasileiros. In: ABRAMO, H. W.; BRANCO, P. P. (Org.). Retrato da juventude brasileira: análise de uma pesquisa nacional. São Paulo: Instituto Cidadania/Editora Fundação Perseu Abramo, 2005, p. 175-214.

BOULlÓN, R. C. Atividades turísticas e recreativas: o homem como protagonista. São Paulo: EDUSC Bauru, SP, 2004, p. 208.

BRUHNS, H. Explorando o Lazer moderno. Movimento, Porto Alegre, v. 10, n. 2, mai/ago, 2004, p. 93-104.

CAMARGO, L. O. L. O que é Lazer? 3. ed., São Paulo: Brasiliense, 1992.

CAMARGO, L. O. L. Educação para o lazer. São Paulo: Moderna, 1998.

CAMARGO, L. O. L. Sociologia do lazer. In: AnSARAH, M. G. dos R. (Org.) Turismo: como aprender, como ensinar. vol. 2. São Paulo: Editora SENAC, 2001, p. 235-275. 
CAMARGO, K. B. R.; SILVA C. H. C. O turismo no município de Presidente Epitácio: produção e consumo do espaço. Rio Claro, 2005.

CARVAlHO, C. L. de. Políticas Públicas no Turismo Brasileiro: a cidade de São Paulo e a construção de sua identidade turística. 2009. 25f. Trabalho de Conclusão de Curso (Tese) Doutorado em Ciências da Comunicação. Escola de Comunicações e Artes da Universidade de São Paulo, São Paulo, 2009.

CASTRO, C. Narrativas e Imagens do turismo no Rio de Janeiro. In: VELHO, Gilberto. Antropologia urbana: cultura e sociedade no Brasil e em Portugal. Rio de Janeiro: Jorge Zahar, 1999, p. 80-87.

CASTRO, M. G. et all. Cultivando vida, desarmando violências. Experiências em educação, cultura, lazer, esporte e cidadania com jovens em situação de pobreza. Brasília: UNESCO, Brasil Telcom, Fundação Kellogg, Banco Interamericano de Desenvolvimento, 2001.

CHEIBUB, B. L. Lazer, experiência turística, mediação e cidadania: Um estudo sobre o projeto turismo jovem cidadão (SESC-RJ). Trabalho de Conclusão de Curso (Dissertação) Mestrado em História, Política e Bens Culturais. Universidade Federal de Minas Gerais, 2009.

CHEIBUB, B. L. A História das práticas turísticas no Serviço Social do Comércio de São Paulo (Sesc-SP). Rosa dos Ventos, v. 6, 2014, p. 247-262.

CRUZ, R. C. Hospitalidade turística e fenômeno urbano no Brasil: considerações gerais. In: DIAS, C. M. (Org.) Hospitalidade: Reflexões e Perspectivas. Barueri/SP: Manole, 2002. 39$56 \mathrm{p}$.

BRUYNE, P.; HERMAN, J.; SCHOUTHEETE, M. Dinâmica da pesquisa em ciências sociais. 5. ed., Rio de Janeiro: Francisco Alves, 1991.

DENCKER, A. F. M. Métodos e técnicas de pesquisa em turismo. 4. ed. São Paulo: Futura, 2007. 
DEMO, P. Participação é conquista. 5. ed. São Paulo: Cortez, 1988.

DEMO, P. Pobreza Política. São Paulo: Cortez/ Autores Associados, 1988b.

DICTORO, V. P; HANAI, F. Y. Simbolismos da água: Valores, saberes e tradições dos moradores de Pirapora-MG nas margens do Rio São Francisco. Revista Gestão e Sustentabilidade Ambiental, v. 6, n. 1, 2017. Disponível em: < http://www.portaldeperiodicos.unisul.br/index.php/gestao_ambiental/article/view/4009 >. Acesso em: 20 de mar. 2017.

DUMAZEDIER, J. Lazer e cultura popular. São Paulo: Perspectiva, 1973.

DUMAZEDIER, J. Valores e conteúdos culturais do lazer. São Paulo: Senac, 1980, p. 176.

DUMAZEDIER, J. Lazer e cultura popular. São Paulo: Perspectiva: 2004.

GIL, A. C et al. Como elaborar projetos de pesquisa. 4. ed. São Paulo: Atlas, 2002.

GODOY, Benedito de. História de Presidente Epitácio. Presidente Epitácio, 2002.

GOMES, C. L. Lazer - Ocorrência Histórica. In: GOMES, C. L. (Org.) Dicionário crítico do Lazer. Belo Horizonte: Autêntica, 2004. 133-141 p.

GOMES, C. L. Lazer, trabalho e educação: relações históricas, questões contemporâneas. 2. ed., Belo Horizonte: Editora UFMG, 2008.

GRABURN, N.H.H. The Eskimos and “Airport Art”. Trans-Acion. V.4, n. 10, 1967.

GRANADO, D. C.; RAMIRO, P. A.. Gestão ambiental aplicada ao turismo no Brasil. In: Juliana Heloisa Pinê Américo-Pinheiro; Elisângela Medina Benini; Allan Leon Casemiro da Silva. (Org.). Meio ambiente: gestão e sustentabilidade. 1ed.Tupã, SP: ANAP, 2017. Disponível em: < https://www.editoraanap.org/livro-gestao-ambiental-e-sustentabi> Acesso em: 15 jan. 2017. 
HENRY, R., PANARELli, EA., CASANOVA, SMC., SUIBERTO, MR. \& AFONSO, AAO. Interações hidrológicas entre lagoas marginais e o rio Paranapanema na zona de sua desembocadura na Represa de Jurumirim. In: NOGUEIRA, MG, JORCIN, A. \& HENRY, R. (Eds). Ecologia de reservatórios: impactos potenciais, ações de manejo e sistemas em cascata. 2. ed. Rima, São Carlos, 2006, p. 56-82.

INSTITUTO BRASILEIRO DE GEOGRAFIA E ESTATÍSTICA. Cidade de Rosana. Disponível em: $<$ http://cidades.ibge.gov.br/painel/historico.php?lang=\&codmun=354425\&search=s\%E3opaulo|rosana> Acesso em: 15 jan. 2017.

INSTITUTO BRASILEIRO DE GEOGRAFIA E ESTATÍSTICA. Cidade de Presidente Epitácio. Disponível em: $<$ http://cidades.ibge.gov.br/xtras/perfil.php?lang=\&codmun=354130\&search=saopaulo|presidente-epitacio> Acesso em: 26 fev. 2017.

JULIO Jr., HF., THOMAZ, SM., AGOSTINHO, AA. \& LATINI, JD. Distribuição e caracterização dos reservatórios. In: RODRIGUES, L., THOMAZ, SM., AGOSTINHO, AA. \& GOMES, LC. (Org.). Biocenoses em reservatórios: padrões espaciais e temporais. São Carlos: Rima, São Carlos, 2005, p. 1-16.

KOGA, Dirce. Cidades entre territórios de vida e territórios vivido. Serviço Social \& Sociedade. São Paulo, n. 72, 2002, p. 23-52.

KRIPPENDORF, J. Sociologia do turismo: para uma nova compreensão do lazer e das viagens. 3 ed. São Paulo: Aleph, 2001.

LICKORISH, Leonard; LENKINS, Carson L. Introdução ao Turismo. Rio de Janeiro: Campus, 2000.

LINHALES, M. A. São as políticas públicas para a educação física/esportes e lazer, efetivamente políticas sociais?. In: Motrivivências. Florianópolis: UFSC, 1998, p. 71-81. 
MACEDO, C. C. Algumas observações sobre a questão da cultura do povo. In: VALLE, E. e QUEIROZ, J. (Org.). A cultura do povo. 3. ed. São Paulo: Cortez, 1984, p. 34-39.

MAGNANI, J. G. C. Festa no pedaço: Cultura popular e lazer na cidade. 3. ed. São Paulo: HUCITEC, 2003.

MARCELliNO, N. C. Subsídios para uma política de lazer: o papel da administração municipal. In: MARCELlinO, N. C. (Org.). Políticas públicas setoriais: o papel das prefeituras. Campinas: Autores Associados, cap. 2, 1996, p. 23-30.

MARCELLINO, N. C. Políticas de lazer: mercadores ou educadores? Os cínicos bobos da corte. In: MARCELLINO, N. C (Org.) Lazer e Esporte. Campinas: Autores Associados, cap. 1, 2001, p. 05-29.

MARCELLINO, N. C. Estudos do lazer: uma introdução. 2. ed. Campinas: Papirus, 2000, p. 100.

MARCELlinO, N. C. Estudos do Lazer: uma introdução. 4. ed., Campinas: Autores Associados, 2006.

MARCELLINO, N. C. Lazer e cultura: algumas aproximações. In: MARCELLINO, N. C. (org.). Lazer e cultura. Campinas: Editora Alínea, 2007, p. 219.

MARCELLINO, N. C. Subsídios para uma política de lazer: o papel da administração municipal IN: MARCEllinO, N. C. (Org.). Políticas Públicas de Lazer. Campinas, SP: Editora Alínea, 2008, p. 11-16.

MARCELLINO, N. C.; BARBOSA, F. S.; MARIANO, S. H. Espaços e equipamentos de lazer: apontamentos para uma política pública IN: MARCELLINO, N. C. (Org.). Políticas Públicas de Lazer. Campinas, SP: Editora Alínea, 2008a, p. 133-152.

MARCELlinO, N. C.; BARBOSA, F. S.; MARIANO, S. H. A cidade e o acesso aos espaços e equipamentos de lazer. Revista Impulso. Piracicaba, v. 17, n. 44, 2008b, p. 55-88. 
MARCELLINO, N. C. Lazer e Educação. 17. ed. Campinas: Papirus Editora, 2014.

MARCONI, M. A; LAKATOS, E. M. Técnicas de Pesquisa. 7. ed. São Paulo: Atlas, 2010.

MARINHO, A.; BRUHNS, H. T. (Org.). Turismo, lazer e natureza. São Paulo: Manole, 2003.

MELO, V. A.; ALVES JUNIOR, E. D. Introdução ao Lazer. 2. ed. São Paulo: Manole, 2012.

MENICUCCI, T. Políticas públicas de lazer: questões analíticas e desafios políticos In: ISAYAMA, H.; LINHAlES, M. A (Org.). Sobre Lazer e Política: maneiras de ver, maneiras de fazer. Belo Horizonte: Editora UFMG, 2006, p. 136-164.

MICELI, S. Intelectuais e classe dirigente no Brasil (1920-1945). In: MICELI, S. Intelectuais à brasileira. São Paulo: Companhia das Letras, 2001.

MOESCH, M. M. Turismo e Lazer: conteúdos de uma única questão. In: MARCELLINO, N. C (Org.). Formação e Desenvolvimento de Pessoal em Lazer e Esporte. Campinas, SP: Papirus, 2003, p. 19-30.

MOESCH, M. M. A origem do conhecimento, o lugar da experiência e da razão na gênese do conhecimento do Turismo. $5^{\circ}$ Congresso Latino-americano de Investigação Turística, 2012, p. 1-15.

NAKATA, H. C, M. Geografia Geral - Série Sinopse. 1. ed. São Paulo. Ed Moderna, 1979. ORGANIZAÇÃO MUNDIAL DO TURISMO. TSA data around the world. Madrid. 2010. Disponível em: <http://statistics.unwto.org/sites/all/files/pdf/tsa_data.pdf〉. Acesso em: 28 set. 2016.

PRESIDENTE EPITÁCIO. Prefeitura Municipal de Presidente Epitácio. 2017a Disponível em < http://www.presidenteepitacio.sp.gov.br>. Acesso em: 15 abr. 2017. 
PRESIDENTE EPITÁCIO. Plano Diretor. 2017b Disponível em < http://www.presidenteepitacio.sp.gov.br/leis/plano-diretor/lei-complementar-n-50-2006revisao-plano-diretor.pdf>. Acesso em: 15 abr. 2017.

REQUIXA, R. Sugestão de Diretrizes para uma Política Nacional de Lazer. São Paulo: SESC, (Biblioteca Cientifica do SESC - Série Lazer, 2), 1980, p. 103.

RIBEIRO, R. M. SISTEMA DE PLANEJAMENTO DO TURISMO? UMA FERRAMENTA PARA O PLANEJAMENTO TURÍSTICO E TERRITORIAL DE GUARATUBA - PR.Trabalho de Conclusão de Curso (Tese) - Doutorado em Geografia Universidade Estadual do Paraná - UFPR, 2011.

RIBEIRO, R. D. M. ; GRANADO, D. C . Os recursos hídricos como atrativos turísticos em Rosana (SP): gerenciamento, conservação e uso dos ambientes aquáticos para recreação e turismo. In: Francisco A. A.; Newton P. A.; Rosislene F. F. (Org.). Turismo na natureza. 1. ed. Itajaí, SC: Univali, 2015, p. 119-137.

RODRIGUES, M. A. Políticas públicas. 4. ed., São Paulo: Publifolha, 2010.

ROMERO, L. R. ; GRANADO, D. C. Reservatórios em regiões tropicais: reflexões sobre o potencial para turismo, lazer e saúde. In: $12^{\circ}$ Congresso da Água $16^{\circ}$ Congresso de Engenharia Sanitária e Ambiental XVI Simpósio Luso-Brasileiro de Engenharia Sanitária e Ambiental, 2014. 12 $^{\circ}$ Congresso da Água/ 16 $^{\circ}$ ENASB/ XVI SILUBESA: Comunicações e Pôsteres, Lisboa, 2014.

ROSANA. Prefeitura Municipal de Rosana. Disponível em: < http://www.rosana.sp.gov.br/>. Acesso em: 13 jan. 2017.

ROSANA. Plano Diretor de Desenvolvimento Turístico Municipal de Rosana. Disponível em:

http://www.rosanasp.com.br/files/PLanoDiretorParticipativo/PLANO_DIRETOR_DIAGNOS TICO.pdf. Acesso em: 01 mai. 2017. 
ROSANA. Plano Diretor Participativo do Município de Rosana/SP. Disponível em: <http://www.rosanasp.com.br/files/PLanoDiretorParticipativo/PLANO_DIRETOR_DIAGNO STICO.pdf>. Acesso em: 01 mai. 2017.

SAlVATI, S. S. (Org). Turismo Responsável - Manual para Políticas Públicas. Brasília: WWF, 2004.

SECRETARIA DE TURISMO DO ESTADO DE SÃO PAULO. DADETUR. Disponível em: 〈http://www.turismo.sp.gov.br/publico/noticia_tour.php?cod_menu=54>. Acesso em: 15 fev. 2017.

SÁ-SILVA, J. R.; ALMEIDA, C. D.; GUINDANI, J. F. Pesquisa documental: pistas teóricas e metodológicas. Revista Brasileira de História e Ciências Sociais. São Leopoldo, v.1, n.1, p. 1-15, jul. 2009. Disponível em: http://www.rbhcs.com/index_arquivos/Artigo.Pesquisa\%20documental.pdf $>$. Acesso em: 19 out. 2016.

SANTOS FILHO, J. Ontologia do Turismo: estudo de suas causas primeiras. Caxias do Sul, RS: Educs, 2005.

SEVERINO, A. J. Metodologia do trabalho científico. 21. ed. São Paulo: Cortez, 2007.

SOUZA, Celina. Estado da arte da pesquisa em políticas públicas. In: HOCHMAN, Gilberto; ARRETCHE, Marta; MARQUES, Eduardo (Org.). Políticas públicas no Brasil. Rio de Janeiro: Fiocruz, 2007, p. 65-86.

SPOSATI, Aldaíza. Gestão pública intersetorial: sim ou não? Comentários de experiência. Serviço Social \& Sociedade, São Paulo, n. 85, 2006, p. 133-141.

STOPPA, E. A. "Tá ligado mano": o hip-hop como lazer e busca da cidadania. 2005. 143f. Trabalho de Conclusão de Curso (Tese) - Doutorado em Educação Física. Faculdade de Educação Física da Universidade Estadual de Campinas, Campinas, 2005. 
STOPPA, E. A. et. al. Gestão de Esporte e de Lazer: análise dos espaços e equipamentos de esporte recreativo e de lazer na Subprefeitura de Ermelino Matarazzo, Zona Leste de São Paulo. São Paulo: Plêiade, 2011.

TRIGO, L. G. G. A viagem, caminho e experiência. São Paulo: Aleph, 2013.

TRIVIÑOS, A. N. S. Introdução à pesquisa em ciências sociais: a pesquisa qualitativa em educação. São Paulo. Atlas, 2008.

TRIVIÑOS, A. N. S. Introdução à pesquisa em ciências sociais: a pesquisa qualitativa em educação. 1. ed. 22. Reimpr. São Paulo. Atlas, 2013.

URRY, J. O Olhar do Turista: Lazer e Viagens nas sociedades contemporâneas. 3. ed. São Paulo: Studio Nobel: SESC, 2001. 


\section{APÊNDICES}

\section{Apêndice A - Roteiro de entrevista - Gestores}

1. O balneário Municipal é o principal espaço destinado para o lazer do município?

2. O que é considerado como lazer por essa administração?

3. Considera importante a elaboração de políticas de lazer para o Balneário?

4. Como é planejada/pensada a política lazer?

5. Para quem é planejada e qual a principal finalidade?

6. Quais foram realizadas nos últimos anos? Algum projeto não saiu do papel ou não foi bem executada, por quê?

7. Existem projetos para o futuro?

8. Existe participação da comunidade? E de turistas?

8.a. Se sim, como é feita?

8.b. Se não, por quê?

9. Como é realizada a divulgação?

10. Há parcerias diretas com outras secretarias/divisões?

10.a. Se sim, com quais?

10.b. Se não, por quê? 
Apêndice B - Roteiro de entrevista - Morador

1. Visita com frequência o Balneário?

2. Você consegue se lembrar de alguma propaganda a respeito do balneário?

3. Você costuma visitar o balneário com a família ou amigos?

4. O busca ao vir para esse espaço?

5. Realiza quais atividades?

6. Participa de ações promovidas pela prefeitura que envolvem o lazer?

6.a. Se sim, como fica sabendo delas?

6.b. Se não, Por quê?

7. Está satisfeito com a participação da prefeitura nesse espaço?

8. E com as atividades/eventos que ocorrem aqui? 
Apêndice C - Roteiro de entrevista - Turistas

1. De que cidade você vem?

2. Visita com frequência o Balneário?

3. Você costuma visitar o balneário com a família ou amigos?

4. Como ficou sabendo?

5. O busca ao vir para esse espaço?

6. Realiza quais atividades?

7. Você consegue se lembrar de alguma propaganda a respeito do balneário?

8. Participa de ações promovidas pela prefeitura que envolvem o lazer?

8.a. Se sim, como fica sabendo delas?

8.b. Se não, Por quê?

9. Está satisfeito com a participação da prefeitura nesse espaço?

10. E com as atividades/eventos que ocorrem aqui? 